\title{
Systematic in silico discovery of novel solute carrier-like proteins from proteomes
}

\author{
Gergely Gyimesi and Matthias A. Hediger
}

Membrane Transport Discovery Lab, Department of Nephrology and Hypertension and Department of Biomedical Research, Inselspital, University of Bern, Freiburgstrasse 15, $\mathrm{CH}-$ 3010 Bern, Switzerland.

*For correspondence: Gergely Gyimesi (gergely.gyimesi@dbmr.unibe.ch); Matthias A. Hediger (matthias.hediger@ibmm.unibe.ch).

\section{Abstract}

Solute carrier (SLC) proteins represent the largest superfamily of transmembrane transporters, the systematic analysis of which is hampered by their functional and structural heterogeneity, despite their biological importance. Based on available nomenclature systems, we suspected that many as yet unidentified SLC transporters exist in the human genome. Here, we present criteria for defining "SLC-likeness" and apply them to curate a set of "SLC-like" protein families from the Transporter Classification Database (TCDB) and Protein families (Pfam) databases. Computational sequence similarity searches then surprisingly yielded $\sim 130$ more proteins in human with SLC-like properties, compared to previous annotations. Several of these novel putative SLC transporter proteins actually have documented transport activity in the scientific literature. We complete our overview of the SLC-ome by presenting an algorithm to classify SLC-like proteins into protein families, investigating their known functions and evolutionary relationships to similar proteins from 6 other clinically relevant experimental organisms, and pinpointing structural orphans. We envision that our work will serve as a stepping stone for future studies of the biological function and the identification of the natural substrates of the many under-explored SLC transporters, as well as the development of new therapeutic applications, including strategies for personalized medicine and drug delivery.

\section{Introduction}

The solute carrier (SLC) protein superfamily accounts for about $50 \%$ of all transport-related proteins and $10 \%$ of all membrane proteins encoded by the human genome. With more than 400 annotated members, it is the largest superfamily of membrane transporter proteins [1]. Membrane transporters and channels are the main entry routes for nutrients, ions, xenobiotics and serve as major exit routes for waste products and metabolites. The roles of SLC transporters as cellular gatekeepers, determinants of nutrient homeostasis and facilitators of drug metabolism and drug targeting has recently been revisited [2]. Around $~ 50 \%$ of currently annotated SLCs are predicted to be associated with human disease phenotypes and many SLCs are considered to represent promising drug targets or drug delivery systems or to affect drug ADMET (absorption, distribution, metabolism, extrusion, toxicity). It has recently become evident that the SLC superfamily offers an enormous unexplored therapeutic treasure. But while the list of approved drugs that target transporter proteins is increasing, many promising SLCs still remain unexplored, uncharacterized and underrepresented in the literature.

The SLC nomenclature system has traditionally been used to classify mammalian secondary active and facilitative transporters, including exchangers and antiporters, into families based on sequence identity per enquiry by the Human Gene Nomenclature Committee (HGNC) starting in the early 
bioRxiv preprint doi: https://doi.org/10.1101/2021.11.19.469292; this version posted November 20, 2021. The copyright holder for this preprint (which was not certified by peer review) is the author/funder, who has granted bioRxiv a license to display the preprint in perpetuity. It is made available under aCC-BY 4.0 International license.

1990s [3]. Originally, SLCs assignments have been made for all membrane transport proteins that are not channels, ATP-driven pumps, aquaporins, porins of the outer mitochondrial membrane or ATPbinding cassette $(A B C)$ transporters, having multiple transmembrane spanning segments usually and exhibiting transmembrane transport of a solute, or showing homology to membrane proteins having such features. Due to this construction, the SLC superfamily is structurally and functionally highly heterogeneous and thus most likely evolutionarily polyphyletic in origin. Because of these properties and the lack of common sequence patterns in the different SLC transporters, it has been difficult to assess how many SLC transporters exist in the human genome or which proteins could be predicted as SLC transporters. Proteins were typically added to the SLC system on a case-by-case basis. However, in view of recent requests to add new members into the SLC nomenclature, we suspected that the SLC system might be incomplete.

Despite their heterogeneity, SLC transporters seem to share common properties that probably were evolutionarily selected based on their suitability as facilitative transporters, secondary active transporters or exchangers. A remarkable property is that they have a symmetric inverted repeat architecture, which can be observed based on the available structures [4] and can sometimes also be detected at the sequence level $[5,6]$. Another important aspect is that the currently well-studied SLC transporters seem to follow an alternating access mechanism, meaning that the substrate-binding site is exposed on either one or the other side of the membrane, but not on both sides simultaneously $[7,8]$. Consequences of these properties are that SLC transporters typically contain many transmembrane helices (TMHs), and functionally exhibit saturable transport activity. In addition, most but not all SLC carriers transport water-soluble small molecules. These properties could be used as criteria to identify additional SLC transporter proteins.

In fact, there have been earlier attempts to gather additional SLCs from the human genome [9-11], as well as to classify them using automatic methods [12,13]. In this regard, one study [9] used BLAST searches to find SLC transporters that have local sequence similarities and found that 15 of the known SLC families fall into 4 phylogenetic clusters, which were termed $\alpha, \beta, \gamma$, and $\delta$ groups. In addition, they have found 19 sequences that have previously not been described as SLCs. A later study [12] used a more sensitive HMM-HMM comparison-based method to identify locally similar regions in known SLC proteins. Visualization of the similarity network revealed visible protein clusters that correlated with existing SLC families. In addition, they identified two unannotated protein sequences that showed similarity to existing SLC proteins. A common limitation of these studies, however, is that they only searched for proteins that were similar to proteins already annotated as human SLC transporters. Nevertheless, these efforts using sequence similarity-based approaches have highlighted that there are additional as yet unannotated SLC transporters in human protein databases.

In our current study, we aimed to identify putative SLC transporters that might differ from those currently annotated in human. To do this, we turned to sequence databases and annotation systems that are phylogenetically broader and not limited to human proteins, and we developed criteria to define "SLC-like" proteins. Our method is thus more general than previous approaches and tackles the task of identifying SLC transporters on a semantic level. For this reason, we turned to the Transporter Classification DataBase (TCDB) to enable the extraction of missing SLC-like proteins.

The Transporter Classification DataBase (TCDB) is an alternative classification system that was created in the 1990 s in parallel to the SLC nomenclature series $[14,15]$. It collects transport-related membrane proteins, including membrane receptors, transporters, ion channels, and membraneanchored enzymes from all kingdoms of life, with a particular focus on proteins from lower organisms. The proteins in the TCDB are organized hierarchically into subfamilies, families and superfamilies based on phylogenetic and functional considerations, and each member in the database is given a five-segmented TC\# similar to the EC\# that is used for enzyme classification. In addition, a brief description is provided for each family that introduces identified members and contains links to the most important relevant papers. 
bioRxiv preprint doi: https://doi.org/10.1101/2021.11.19.469292; this version posted November 20, 2021. The copyright holder for this preprint (which was not certified by peer review) is the author/funder, who has granted bioRxiv a license to display the preprint in perpetuity. It is made available under aCC-BY 4.0 International license.

However, the TCDB dataset is not directly applicable for creating an overview of the human SLCome. One of the reasons is that the TCDB is set up as a "representative database", which means that it only contains certain representative sequences from each family. In addition, there is no particular focus on human proteins, and in fact several annotated human SLC transporters are not present in the database.

It also seems problematic to consider all proteins in the TCDB that are annotated as part of the secondary transporter superfamily TC \#2.A as being SLC-like. Indeed, many of the TCDB families annotated as part of TC \#2.A exhibit structural or sequence features that do not match the characteristics of existing SLCs. Examples of this are the Trk $\mathrm{K}^{+}$transporters (\#2.A.38), which display an ion-channel like structural fold [16], the GUP glycerol uptake proteins (\#2.A.50), which exhibit based on follow-up studies enzymatic activity [17], and the Twin Arginine Targeting (Tat) family (\#2.A.64), which are actually protein secretion complexes $[18,19]$. Since none of these families correspond to structural or functional characteristics of currently known SLC transporters, it is likely that not all proteins annotated under the TC \#2.A superfamily are "SLC-like". Thus, while the TCDB could be a rich source of information for finding new transporters, it is clear that the perception of what a "transporter" should be according to TCDB does not always correspond to the typical properties of well-characterized SLC proteins. Additional filtering of TCDB data is therefore necessary.

As part of the TransportDB project, there were parallel efforts to collect secondary transporters from human and several other organisms [20-22]. To this end, the authors have built an automatic transporter annotation pipeline (TransAAP), which relies on BLAST searches, the Clusters of Orthologous Groups (COG) database [23], "selected HMMs for transporter protein families" [22] from the TIGRfam and Pfam databases [24,25] and hydropathy predictions of TMHMM [26]. This pipeline was used as a semiautomatic tool to annotate transporter-like proteins from the NCBI RefSeq database. However, based on the currently available TransportDB website, the resulting protein hits are neither linked to protein annotation databases, such as UniProt [27], nor are their official gene symbols or SLC names displayed. Therefore, no correlation with the existing SLC nomenclature is provided, and it is not trivial to say whether or not an existing SLC protein is included in the database.

Therefore, there is a clear need in the field to define the criteria of "SLC-likeness" and to identify and classify all proteins in humans and other species that exhibit "SLC-likeness". Thus, in our work, we have added semantic content to the term "SLC-likeness" by defining the essential criteria for it, and we have carried out an exhaustive search for proteins meet these criteria, both with manual curation of datasets and with automatic sequence similarity-based approaches.

\section{Results}

\section{Elaboration of criteria for "SLC-likeness"}

Since the TCDB takes a very inclusive approach to collecting membrane transport-related proteins from a broad range of biological organisms, we have selected it as the source database for our endeavors. However, as outlined in the introduction, selecting SLC-like proteins from the TCDB is non-trivial. Therefore, we have introduced a set of criteria based on current knowledge of SLC transporters in order to select SLC-like protein families from the TCDB. We believe that these criteria represent the most important properties of currently known SLC transporters. However, due to missing information, these criteria could not always be verified while filtering the TCDB for SLC-like protein families. Therefore, the criteria themselves were neither formulated very specifically nor strictly enforced, but merely served as a guideline during the selection process, and exceptions were made in several cases. The criteria used to infer "SLC-likeness" were as follows.

- Structure of the protein should be $\alpha$-helical, with at least three transmembrane helices (TMHs). In exceptional cases, 2-TMH families were also included, but $\beta$-barrel proteins, mostly 
bioRxiv preprint doi: https://doi.org/10.1101/2021.11.19.469292; this version posted November 20, 2021. The copyright holder for this preprint (which was not certified by peer review) is the author/funder, who has granted bioRxiv a license to display the preprint in perpetuity. It is made available under aCC-BY 4.0 International license.

$\beta$-structure proteins, membrane-anchored proteins, cyclic peptides and proteins consisting only of soluble domains (based on predictions or structural data) were excluded.

- The size of the transported substrate should fall within the small-molecule range (i.e. oligopeptides might be accepted as substrates but protein secretion systems are excluded). Also excluded are DNA-, RNA- and polysaccharide-transporting systems.

- Proteins where transport activity was used as a synonym for trafficking (i.e. protein or vesicle translocation within the cell) but otherwise seemingly having no small-molecule transmembrane transport activity were excluded. On this basis, chaperones and other proteins helping the insertion of nascent proteins into a cellular membrane were also excluded.

- Proteins with a channel-like mechanism were excluded, except in some rare cases. In particular, holins, toxins and other pore-forming proteins, and proteins bearing similarity to them, have been excluded.

- Proteins with enzymatic activity, or similarity to known enzymes were excluded. In some cases, where the protein was believed to contain both a transport domain and a soluble enzyme domain, the proteins have been included.

- Receptors that trigger endocytosis upon substrate binding were excluded. Only receptors were included where the receptor protein itself mediates the translocation of the substrate through the membrane, or the insertion of the substrate in the membrane, if that is its final location.

- ATP- and GTP-dependent transporters (e.g. ABC, ECF) were excluded.

- For some (mostly putative) transporter families, TCDB does not give an explanation why the proteins would be considered as transporters. Families with no resemblance to known transporters and no indication or argument as to why they would be transporters were excluded.

We believe that our criteria are sufficiently broad to allow the identification of all putative SLC-like transporters, while also being specific enough to distinguish them from other well-known, nontransport-related transmembrane protein families. In general, our criteria represent the first attempt to set up semantic guidelines defining "SLC-likeness", and proteins and protein families that meet the above criteria are referred to as "SLC-like" in our current study.

\section{Search for novel "SLC-like" proteins}

The above-mentioned criteria were applied to manually select protein families in the TCDB that fulfill these criteria based on the description of each third-level family from the TCDB database. Throughout this manuscript, we use the term "TCDB family" to refer to third-level groupings in the classification hierarchy (i.e. TC\# x.y.z), while "subfamily" and "superfamily" refer to fourth-level (TC\# x.y.z.w) and second-level (TC \#x.y) classes, respectively. In the work presented herein, we have analyzed superfamilies TC \#1.A, \#2.A, \#9.A and \#9.B and the families, and in certain cases the subfamilies within them (see Table 1 ).

It was a significant curation effort to manually assess the 1534 subfamilies within 616 families in the above-mentioned superfamilies of the TCDB, which were expected to contain SLC transporter-like proteins (Table 1). In many cases, information from the scientific literature, transmembrane segment prediction (see Methods) or structural databases were taken into account in order to determine whether a particular family fulfills the "SLC-likeness" criteria. Strikingly, of the 1534 subfamilies examined, only 602 in 167 families were found to be SLC-like according to our criteria. In particular, of the 556 subfamilies within superfamily TC\# 2.A ("porters"), only 501 appeared to meet our selection criteria. This underlines once more that the term "porter" in relation to solute transport ambiguous in this field and a clearer definition of the perception of a solute transporter protein is needed.

To streamline our curation efforts, we have expanded our analysis to include protein domains stored within the Pfam database [28], which aims to maintain a curated set of protein families, often 
bioRxiv preprint doi: https://doi.org/10.1101/2021.11.19.469292; this version posted November 20, 2021. The copyright holder for this preprint (which was not certified by peer review) is the author/funder, who has granted bioRxiv a license to display the preprint in perpetuity. It is made available under aCC-BY 4.0 International license.

represented by functional domains. Notably, Pfam provides curated Hidden Markov-Models (HMMs) for each Pfam family to facilitate sequence similarity searches for the occurrence of those domains. At the same time, Pfam neither attaches importance to transport-related domains nor to membrane-spanning domains, but groups protein families into higher-order groups called clans. Pfam clans contain evolutionarily related families whose relationships are supported either by sequence similarity, structural similarity or other orthogonal biological evidence [29]. As part of our study, we asked which Pfam families describe functionally relevant membrane-spanning regions of SLC-like transporters. To this end, we used HMMER [30] to search for all Pfam families in the sequences of all TCDB members within the four superfamilies analyzed, as shown in Table 1. This was followed by a manual curation step in which the resulting Pfam families were filtered according to the same criteria that were applied to the selection of SLC-like families from the TCDB (see above), based on the descriptions of the families on the Pfam-website as well as the scientific literature. Special care has been taken to consistently include or exclude TCDB (sub)families and their corresponding Pfam family, if applicable. Our goal was to identify a set of Pfam families that describe the functional membrane-spanning regions of SLC-like transporters.

These curation efforts yielded 211 Pfam families bearing "SLC-like" properties, which likely contain the membrane-spanning regions of SLC-like proteins selected from the 336 Pfam families present in total in the TCDB sequences analyzed. Notably, many of those Pfam families that have been excluded represented soluble structural or regulatory domains. Following this initial round of selection, we took advantage of clan groupings in Pfam and extended our selection efforts to analyze Pfam families belonging to the same clan as the selected 211 SLC-like Pfam families. This was based on the observation that many SLC-like transporter families in Pfam appear grouped into clans, so that members of these clans might represent SLC-like transporters themselves. Such a "clan expansion" procedure resulted in 12 additional Pfam families that are evolutionarily related to SLClike protein families, of which 8 Pfam families met our criteria as SLC-like. Interestingly, these 8 SLClike Pfam families currently have no representatives with a modest score (bit score $>25$ ) in the TCDB, while 4 of the 8 families are annotated in Pfam as domains of unknown function (DUF). Thus, a total of 219 SLC-like Pfam families were identified in our search (see Supplementary Table 1).

As a next step, we wanted to know whether the selected families either from the TCDB or from Pfam have representatives in the proteomes of human and other clinically relevant organisms. For this analysis, we selected 7 organisms due to their clinical relevance or scientific utility (H. sapiens, $R$. norvegicus, M. musculus, G. gallus, D. rerio, D. melanogaster, $C$. elegans), for which we downloaded all sequences from the UniProt database [27], including Swiss-Prot (curated) and TrEMBL (predicted) [31] entries. Sequences of proteins in the TCDB have been aligned within each SLC-like family and subfamily and the alignments converted to HMMs for sensitive sequence similarity searches (see Methods). In addition, HMMs of SLC-like Pfam families were downloaded from the Pfam database. HMM-based similarity searches were then performed on the sequences downloaded for the 7 organisms to find proteins similar to any of the SLC-like TCDB families or subfamilies, or SLC-like Pfam domains, followed by the clustering of sequence fragments to arrive at one representative protein sequence per gene (see Methods).

The results of our search for SLC-like proteins are summarized in numbers in Table 2. Briefly, 60-68 of the 167 TCDB families have representatives in the 7 organisms (67 in human), and the organisms seem to contain 435-676 SLC-like proteins (552 in human). In total, 3750 proteins have been found in the 7 organisms studied. Notably, the number of SLC-like transporters found in human in our search is $\sim 130$ higher than previously reported [1], indicating that the human SLC-ome may be significantly larger than previously thought.

After arriving at this initial set of SLC-like proteins, we proceeded by attempting to classify the proteins into protein families, as detailed below, followed by manual database and literature searches focused on outlier proteins (single protein in a family) and human proteins in order to exclude false positives, as detailed below. This process was repeated iteratively to finally arrive at a 
bioRxiv preprint doi: https://doi.org/10.1101/2021.11.19.469292; this version posted November 20, 2021. The copyright holder for this preprint (which was not certified by peer review) is the author/funder, who has granted bioRxiv a license to display the preprint in perpetuity. It is made available under aCC-BY 4.0 International license.

consistent set of proteins and corresponding families. The numbers mentioned below correspond to this final set of proteins, and all subsequent analysis was carried out on this set.

\section{Classification into families}

As mentioned in the introduction, SLC carriers are likely of polyphyletic origin, and individual families can be so diverse that even sensitive sequence similarity-based methods may have difficulties grouping related SLCs [12]. In our experience, multiple sequence alignment-based methods were not able to cluster the identified SLC-like sequences and to recapitulate them in known SLC families, so we devised a custom method for clustering distantly related sequences into proteins families based on the introduction of "HMM fingerprints". An HMM fingerprint is a mathematical vector of numbers assigned to a protein sequence, where the numbers represent the similarity scores of that protein sequence against each of the TCDB families, subfamilies and Pfam families that we have selected to be SLC-like. Thus, two protein sequences that show a similar pattern in their HMM fingerprints indicate their similarity. The usefulness of an HMM fingerprint depends on a meaningful definition of HMMs used in the fingerprint, whereby we capitalize on the evolutionary principle in the construction of TCDB families, subfamilies as well as Pfam families. Nevertheless, our goal was not to reconstruct the evolutionary history of a set of proteins, but to group proteins that share similar sequence features. However, due to the transitivity of homology and since similarity to a group of proteins suggests homology, clusters derived using HMM fingerprinting are likely to contain homologous proteins.

The HMM fingerprint-based classification of the SLC-like proteins found in our search yielded 103 protein families in total, 94 of which had representatives in human (Figure 1). For existing SLC transporters, the generated families corresponded well to classical SLC families. Interestingly, outlier proteins were found in several families that did not cluster with their families at the threshold we used. Examples include SLC5A7, SLC10A7, SLC25A46, SLC30A9, SLC39A9, MPDU1/SLC66A5 as well as the SLC9B family and SLC35 subfamilies. This shows that the HMM fingerprints, and thus likely the sequences of these outlier proteins diverge from those of other members of their families, and the sequences of subfamilies seem to diverge in certain cases. Several classical SLC families also clustered together, such as SLC32-SLC36-SLC38, SLC2-SLC22, and SLC17-SLC18-SLC37 proteins, likely due to their high sequence similarity. In these cases, we have adjusted the threshold value to arrive at clusters that better correspond to existing SLC classification (see Methods).

Our analysis revealed 43 new proteins families in total in human, containing proteins that have not yet been annotated as SLCs. Interestingly, our search has also found new proteins that clustered into existing SLC families (Table 3).

Structural similarity analysis, fold assignment

For polytopic transmembrane proteins, structural similarity can provide support for evolutionary relatedness and at the same time a basis for homology-based model building efforts. On the other hand, the lack of predicted similarity to proteins of known structure could pinpoint interesting targets for structural biology efforts by highlighting proteins that are likely to belong to new fold families.

We performed HMM-based searches on the pdb70 database (sequences of the proteins in the Protein Data Bank clustered to $70 \%$ sequence identity, see Methods) to assess whether structural homologues are available for the proteins found. In total, for 80 of the 103 families, at least one similar protein was found with a corresponding structure in the Protein Data Bank. Importantly, 476 human SLC-like proteins have a homologue whose structure has been solved. On the other hand, 43 human SLC-like proteins belonging to 19 different families do not have homologues with a known structure and thus are likely to constitute novel fold families. For the classical SLC proteins, their best-scoring similar proteins from the pdb70 dataset and the corresponding structural fold families are summarized in Supplementary Table 3. Based on this, it appears that classical SLCs from families SLC34, SLC44, SLC48 and SLC51 are still "structural orphans". 
bioRxiv preprint doi: https://doi.org/10.1101/2021.11.19.469292; this version posted November 20, 2021. The copyright holder for this preprint (which was not certified by peer review) is the author/funder, who has granted bioRxiv a license to display the preprint in perpetuity. It is made available under aCC-BY 4.0 International license.

\section{Phylogenetic analysis}

Model organisms can be useful to study the biological function of various proteins, including solute transporters. In order to relate the results to human, however, knowledge of orthologous gene pairs is necessary. To this end, we performed phylogenetic analysis on each family of SLC-like proteins corresponding to our clustering. In brief, unrooted phylogenetic trees for each SLC-like protein family from all organisms have been generated and reconciled with the species tree of the 7 organisms in our study to identify gene duplication and speciation events in their evolutionary history (see Methods). The resulting evolutionary trees are deposited in Supplementary File 1. Based on these trees, we carried out orthology analysis focused on human proteins and the human lineage. The resulting data is presented in Figure 2, showing relationships between human genes and their orthologs in the other 6 organisms in our study. In addition, gene clusters are presented that have arisen through gene duplication events in the evolutionary history of the human lineage, but the corresponding human genes have likely been lost.

\section{Literature search on newly found SLC-like proteins}

As alluded to above, our initial search was followed by thorough investigation of the available literature to check whether a description of transport activity for the newly found proteins is available. Surprisingly, our search has revealed human proteins for which transported substrates are known. These data have been included in Table 3.

We also found several sequences that we believe could be false positives for various reasons. These can be fragments of other proteins, non-human proteins, translated sequences of pseudogenes or proteins that have shown partial similarity to existing transporters or proteins in Table 3, but have well-known non-transporter functions. These proteins have been omitted from Table 3, and are instead summarized in Supplementary Table 2. After such filtering, 3676 SLC-like proteins have remained, out of which 519 were from human, and 130 of them were from non-classical SLC families, indicating putative novel SLC-like proteins.

\section{Discussion}

Our curation and search efforts have revealed a surprising 130 human proteins that are SLC-like but were not officially part of the SLC nomenclature. Interestingly, around 30 of them were addressed in an earlier study and referred to as "atypical SLC transporters" [10,11]. All of these atypical transporters have also been identified in our study, together with many others, including several that are not part of the major facilitator superfamily (MFS) or the amino acid-polyamine-cation (APC) transporter superfamily.

In the following sections, we discuss the resulting set of SLC-like proteins with special focus on the identities of the transported substrates and, if known, the structural and mechanistic aspects of transport. In certain cases, the proteins have already been officially included in the SLC nomenclature, following approval by the Human Gene Nomenclature Committee (HGNC). Where existing information about substrate and function is not available, we have speculated on these aspects using available information in the literature and considerations on sequence similarity. For several proteins, their classification will require further consideration. We also would like to articulate open questions about what further work is needed in order to identify further transporters. We believe that our approach has been useful to pinpoint proteins that have a high possibility of being novel transporters. Thus, specific biological, biochemical or structural efforts could focus on these specific targets highlighted in our work, all of which would contribute to a complete assessment of the SLC-ome in human cells.

\section{Transporters with existing evidence for transport function}

Importantly, our search highlighted several proteins for which our literature search uncovered previously reported evidence of transporter activity. Several of the proteins in these families have been assigned SLC family numbers and, in collaboration with the HGNC, included in the SLC 
bioRxiv preprint doi: https://doi.org/10.1101/2021.11.19.469292; this version posted November 20, 2021. The copyright holder for this preprint (which was not certified by peer review) is the author/funder, who has granted bioRxiv a license to display the preprint in perpetuity. It is made available under aCC-BY 4.0 International license.

nomenclature. Among these hits are several mitochondrial transporters (MPC/SLC54, LETM/SLC55, Sideroflexins/SLC56), which have been reviewed before [32]. In terms of transported substrate, many of the proteins with documented transport activity appear to be ion transporters or exchangers (Table 3). In the next paragraph, we will highlight certain proteins and families that have particularly caught our attention.

Interestingly, the SLC60 family contains two MFS-like proteins (MFSD4A, MFSD4B), of which MFSD4B has been shown to transport D-glucose and urea [33,34].

The SLC61A1 protein (MFSD5) is the only protein in human that shows similarity to the \#2.A.1.40 family of molybdate transporters and contains the "MFS_5" Pfam domain. It has been claimed to be the homolog of similar transporters from algae and plants, and complementation assays suggested its ability to transport molybdate [35]. While molybdenum is a biologically active trace element, not much is known about its transport and homeostasis in human [36].

Interestingly, the TMEM163 protein clustered together with SLC30 zinc transporter (ZnT) proteins, since the "Cation_efflux" Pfam domain, representative of the SLC30 family, was present in its sequence, although at a low score and non-significant e-value (2.9e-3). In the TCDB, TMEM163 is also classified under subfamily \#2.A.4.8, sharing a common family with SLC30 transporters (\#2.A.4.2). Multiple sequence alignment as well as pairwise alignments with existing SLC30 members reveal very low sequence identity with SLC30 proteins (4.2-14.4\%), albeit these numbers are similar to those of SLC30A9 (6.5-13.4\%). Given the marginal similarity to the "Cation_efflux" domain, it is tempting to assume that SLC30 proteins and TMEM163 are distantly related. Indeed, TMEM163 has been shown to bind [37] and transport $\mathrm{Zn}^{2+}$ [38-40], and substitution of its proposed substratebinding residues with alanine abolished $\mathrm{Zn}^{2+}$ efflux activity [40]. Transport has been demonstrated to be $\mathrm{H}^{+}$-coupled, and the protein functioning as a dimer [38], while extruding $\mathrm{Zn}^{2+}$ from the cell [40]. Intracellularly, TMEM163 was originally shown to be expressed in synaptic vesicles [41]. In overexpression systems, it is localized to both the plasma membrane and intracellular membrane compartments [40]. TMEM163 has been linked to Parkinson's disease (PD) [42], even though the opposite conclusion has also been drawn [43]. TMEM163 has also been reported to be upregulated by olanzapine, a psychotropic drug prescribed for PD patients [44]. In addition, TMEM163 was also shown to be highly expressed in insulin secretory vesicles in human pancreas [45], and has been identified as a risk factor in type 2 diabetes $[46,47]$. Disruption of TMEM163 expression might impair insulin secretion at high glucose stimuli [45].

The TMEM165 protein clustered into its own family and is the only protein in human containing the "UPF0016" Pfam domain and showing similarity to TCDB family \#2.A.106.2. TMEM165 is a member of a highly conserved family of transmembrane proteins that is present in many species of eukaryotes and bacteria [48]. Initially, TMEM165 and its yeast homolog, Gdt1p, have been hypothesized to be $\mathrm{Ca}^{2+} / \mathrm{H}^{+}$exchangers $[49,50]$. However, recently, evidence has been mounting about its involvement in manganese $\left(\mathrm{Mn}^{2+}\right)$ homeostasis [50], and both $\mathrm{Ca}^{2+}$ and $\mathrm{Mn}^{2+}$ transport activity has directly been shown [51]. TMEM165 is localized to the trans-Golgi in human cells [48], and is proposed to play a crucial role in regulating $\mathrm{Mn}^{2+}$ uptake into the Golgi apparatus $[48,50]$. In line with this, its homologs in other organisms, also containing the UPF0016 domain, are also annotated as $\mathrm{Mn}^{2+}$ transporters [50]. Manganese plays an important role as a co-factor for enzymes involved in glycosylation, and impairment of TMEM165 function results in glycosylation defects. Indeed, mutations of TMEM165 found in patients with congenital disorder of glycosylation (CDG) type II hamper the transport function or localization of TMEM165 [51]. Due to the importance of TMEM165 in lactate biosynthesis [52], it has also been suggested that TMEM165 could be a transporter importing both $\mathrm{Ca}^{2+}[53]$ and $\mathrm{Mn}^{2+}$ into the Golgi in exchange for protons [50]. TMEM165 proteins contain two copies of the UPF0016 domain, and each domain contains a signature motif, E$\varphi-G-D-(K / R)-(T / S)$, where $\varphi$ denotes a hydrophobic amino acid. The glutamic acid of the second motif, E248, has been shown to be crucial for affecting the glycosylation function of the Golgi but not the expression of the protein [54], and so can be speculated to form part of a binding site for 
bioRxiv preprint doi: https://doi.org/10.1101/2021.11.19.469292; this version posted November 20, 2021. The copyright holder for this preprint (which was not certified by peer review) is the author/funder, who has granted bioRxiv a license to display the preprint in perpetuity. It is made available under aCC-BY 4.0 International license.

transporter function. However, in the absence of an experimentally determined structure, further investigation will be required to understand the transport mechanism of TMEM165.

\section{Proteins with sequence similarity to existing transporters}

Our search uncovered a large number of proteins that show sequence similarity and thus possible relationships to existing transporters in the SLC nomenclature. Since transport activity has not been demonstrated, these proteins are either orphan transporters or they could have transceptor functions. What follows is a comprehensive discussion of these proteins, as their similarity to transporters makes them ideal targets for further studies to elucidate their putative transporter activity.

Atypical transporters

A previous effort by Perland and coworkers has uncovered novel transporter-like proteins mostly from the MFS and APC superfamilies [11], which have also been recognized by our search. In general, the function of these atypical transporters is not well known, but some have been reported to be expressed in the brain, and their expression levels seem to be affected by nutrient availability [55-58]. For MFSD1, MFSD6 and UNC93A, the study of the D. melanogaster and C. elegans orthologs have provided some information on the loss-of-function phenotype [59-62]. MFSD8 and MFSD10 have been linked to the Wolf-Hirschhorn syndrome and to LINCL (late-infantile-onset neuronal ceroid lipofuscinoses), respectively $[63,64]$, and MFSD8 seems to be localized in the lysosomes $[65,66]$. More studies about the biological function and transport activity of these proteins is required to fully understand their physiological roles.

Some of the "atypical" SLC-like transporters (e.g. MFSD8, MFSD9, MFSD10 and MFSD14 proteins) clustered together with members of the classical SLC18 family, which prompted us to examine the relationship of these and neighboring proteins in more detail. We constructed multiple alignments and a phylogenetic tree of the proteins one level above these proteins in our clustering dendrogram (i.e. members of the SLC17, SLC18, SLC37 families as well as MFSD8, MFSD9, MFSD10, MFSD14A-C and SLC22A18 proteins, Figure 3). As expected, the phylogenetic tree gives a better separation of these very similar proteins than the HMM fingerprint-based dendrogram, and the branch support values suggest a clear separation of the SLC17, SLC18 and SLC37 families. In addition, the phylogenetic tree highlights that the atypical SLC proteins MFSD8, MFSD9, MFSD10, MFSD14A-C as well as SLC22A18, while being more divergent, are likely to have evolved from a single common ancestor. The relationship between the MFSD9, MFSD10 and MFSD14A-B proteins also agrees with earlier studies [Perland2017a, Perland2017b]. Similarly, the evolutionary dendrogram created using all 7 organisms in our study for the SLC18 family (Supplementary File 1) suggests that MFSD9, MFSD10, MFSD14A-B and SLC22A18 likely share a common evolutionary origin and are thus more closely related to each other than to SLC18 proteins, while MFSD8 is more distantly related. Further studies may be required to elucidate the particular evolutionary relationship between these proteins.

Interestingly, MFSD3 has clustered together with the SLC33A1 protein in our HMM fingerprint-based clustering analysis. Indeed, the "Acatn" (Acetyl-coenzyme A transporter 1) Pfam domain is present in MFSD3, albeit with a relatively low score, but with significant e-value (5.6e-12). Sequence alignment between SLC33A1 and MFSD3 gives $18.2 \%$ sequence identity. Even though the sequence identity between MFSD3 and SLC33A1 is relatively low, the "Acatn" domain was found only in these proteins. The relatedness of MFSD3 and SLC33A1 is also corroborated by previous results of other groups [57]. The biological function of MFSD3 is still unclear $[57,67,68]$.

The TMEM104 protein in our analysis clustered together with amino acid transporter families SLC32, SLC36 and SLC38. Based on multiple and pairwise sequence alignments and sequence identity, TMEM104 was most similar to SLC38A7 (13.3-15.1\%), SLC38A8 (13.1-15.1\%), and SLC36A1 (10.916.1\%). Interestingly, TMEM104 also bears moderate similarity to the "Aa_trans" Pfam domain, which describes the transmembrane region of SLC38 proteins. In our SLC classification dendrogram 
bioRxiv preprint doi: https://doi.org/10.1101/2021.11.19.469292; this version posted November 20, 2021. The copyright holder for this preprint (which was not certified by peer review) is the author/funder, who has granted bioRxiv a license to display the preprint in perpetuity. It is made available under aCC-BY 4.0 International license.

(Figure 1), TMEM104 clustered with SLC38 proteins, even though it seems to be an outlier from the family, similarly to SLC38A9. In addition, TMEM104, SLC38A7 and SLC38A8 all show low similarity to the "Trp_Tyr_perm" Pfam domain, which describes bacterial tyrosine and tryptophan permeases. Despite the low sequence similarity to SLC38 members, these data suggest that TMEM104 might be an amino acid transporter distantly related to the SLC38 family. To get a more detailed picture of the evolutionary relationship of TMEM104 and the SLC38, SLC36 and SLC32 families, we constructed a multiple alignment and a phylogenetic tree of these proteins (Figure 4). While the tree undoubtedly separates the SLC32 and SLC36 clades due to high branch support values, TMEM104 could not be clearly separated from the SLC38 family, and it likely has a similar relationship to the rest of the family as SLC38A9, playing a transceptor role in cells. However, there is currently no experimental evidence of this and the biological function of TMEM104 remains elusive.

\section{Proteins similar to SLC35 transporters}

Interestingly, our search revealed several proteins that show sequence similarity to transporters of the SLC35 family. SLC35 proteins are currently classified into subfamilies A-G, which have relatively low sequence identity among them (4.0-22.0\%). SLC35 transporters belong to the family of "DMT" (drug-metabolite transporters), which is classified in TCDB family \#2.A.7, and corresponds to a clan of Pfam families, called DMT. Currently known substrates of human SLC35 members include nucleotide-sugar conjugates [69]. However, the substrate range of this superfamily is substantially larger [70].

The TMEM144 proteins harbors its dedicated Pfam domain called "TMEM144", which itself is a member of the DMT clan of transporters. Its relatedness to the DMT family is further corroborated by high-scoring similarity of the TCDB subfamily \#2.A.7.8 to the sequence of TMEM144. Otherwise, functionally, the protein is uncharacterized, although it might be related to sterol metabolism/transport, because its function has been linked to bovine milk cholesterol levels [71], the hypothalamic-gonadal axis and testosterone response [72]. It is also highly expressed in the hypothalamus [72].

TMEM234 is classified in the TCDB \#2.A.7.32 family and also contains a corresponding "TMEM234" Pfam domain, which is a member of the "DMT" clan of Pfam domains as well. The physiological role of TMEM234 is not known. However, in zebrafish, its homolog might play a role in the formation of the kidney filtration barrier, as its knockdown causes proteinurea [73].

In our clustering analysis, TMEM241 clustered with the SLC35 family very closely. Its HMM fingerprint shows similarity to the TC \#2.A.7.13 subfamily, and weak similarity to the "TPT" Pfam domain (which also belongs to the "DMT" Pfam clan) over the whole length of the protein. The proteins in the \#2.A.7.13 family are Golgi GDP-mannose:GMP antiporters from plants, yeast and other organisms $[74,75]$, but not from vertebrates. Nevertheless, the protein seems to be present in many higher organisms according to the Swiss-Prot database. However, these protein are not listed in the TCDB. The biological function of TMEM241 is still unknown, but it has been suggested to affect serum triglyceride levels [76].

Due to the sequence diversity of the SLC35 family, we were interested in the relationships between individual proteins. To this end, we have built a phylogenetic tree of human proteins that showed similarity to existing SLC35 transporters (Figure 5). In the tree, most SLC35 subfamilies could be resolved as a single clade, while TMEM241 and TMEM234 form clades with SLC35D and SLC35F3-5 proteins with a support value of 0.91 and 0.71 , respectively. The relationship of TMEM241 with the SLC35D subfamily is also supported by our HMM fingerprint-based clustering results. TMEM241 shows 12.0-21.4\% sequence identity with SLC35D proteins. In contrast, our phylogenetic tree with SLC35 proteins from all 7 organisms (Supplementary File 1) indicated that TMEM241 is most closely related to SLC35E4. On the other hand, TMEM234 only weakly associated with SLC35F proteins, with sequence identities $3.6-9.2 \%$. TMEM144 appears to be only distantly related to SLC35 proteins. The 
bioRxiv preprint doi: https://doi.org/10.1101/2021.11.19.469292; this version posted November 20, 2021. The copyright holder for this preprint (which was not certified by peer review) is the author/funder, who has granted bioRxiv a license to display the preprint in perpetuity. It is made available under aCC-BY 4.0 International license.

elucidation of evolutionary relationships between proteins in the SLC35 thus likely requires further investigation.

\section{Others}

GPR155 is an enigmatic protein that seems to be a concatenation of a membrane transporter domain (Pfam: "Mem_trans") and a G-protein coupled receptor (GPCR) domain, which might be the reason why it is annotated as a GPCR. The membrane transporter part seems to be most similar to TCDB \#2.A.69.3 subfamily proteins, which are annotated as malate/malonate transporters in the Auxin Efflux Carrier (AEC) family (\#2.A.69). Gene structure analysis suggests that the concatenation is real [77], and both the human, mouse and fruitfly proteins seem to contain $17 \mathrm{TMHs}$ according to UniProt annotations.

The "Mem_trans" domain is only present in GPR155 from all human proteins analyzed, and matches the first $10 \mathrm{TMHs}$ of the protein in a $5+5$ arrangement. In our structural search, the second half of this transporter domain (TMHs 6-10) of GPR155 exhibits similarity to the N-terminal half of sodium/bile transporters of the AsbT fold (SLC10 family). On the other hand, the last 7 TMHs of GPR155 (TMHs 11-17) indeed show similarity to GPCR-fold (7-TM) proteins with known structure, with highest similarity to structures of the human Smoothened receptor homolog (PDB ID: 6OT0). Interestingly, in our search, the N-terminal half of the transporter domain of GPR155 did not show any structural homologues.

The precise function of GPR155 still remains elusive. However, because highest expression levels were found in the brain, especially in GABAergic neurons, it might play a role in GABAergic neurotransmission [77]. It also has been suggested that GPR155 might play a role in neurons involved in motor brain function as well as sensory information processing [77]. In D. melanogaster, knockdown of the homologous gene, "anchor", resulted in increased wing size and thickened veins [78]. This phenotype was similar to what appeared in bone morphogenetic protein (BMP) signaling gain-of-function experiments [78]. GPR155 has also been linked to a number of different cancers $[79,80]$.

Somewhat surprisingly, KDEL receptor proteins also turned up in our search (Supplementary Table 2). The structure of KDEL receptors is known and interestingly reveals similarity to the structure of SWEET transporters, having $7 \mathrm{TMH}$ in a $3+1+3$ arrangement [81]. Indeed KDEL receptors have a common evolutionary origin with SWEET as well as PQ-loop transporters [82], which are represented in human by the SLC50 and SLC66 families, respectively. Oddly, while KDEL receptors have been well characterized, they are not known to harbor transport activity.

The RFT1 protein was originally thought to be a scramblase of lipid-linked origosaccharides [83]. However, these molecules have at least 12-14 sugar moieties, so given their size, it is unlikely that a single transporter could catalyze their flipping. Later studies refuted the scramblase concept and suggested instead that RFT1 could serve as an accessory protein to a flippase, but would not act as a flippase itself [84-86].

Nevertheless, the corresponding "Rft1" Pfam domain shows similarity to multidrug and toxic compound extrusion (MATE) transporters (SLC47 family) and belongs to a clan of Pfam domains ("MviN_MATE") that contain transporters as well. In line with this, human RFT1 showed significant similarity to MATE transporters in our search for structural homologs, indicating likely structural similarity. Some members of the corresponding TC \#2.A.66.3 subfamily also contain weak hits of the "MatE" Pfam domain. Thus, while RFT1 shows similarity to existing transporters, its biological function is still unclear.

The C-terminal half of the TMEM245 protein shows weak similarity to TC \#2.A.86 proteins (Autoinducer-2 Exporter/AI-2E family), which contain both small-molecule exporters $[87,88]$ as well as $\mathrm{Na}^{+} / \mathrm{H}^{+}$antiporter proteins [89-91]. Accordingly, TMEM245 also has weak similarity to the corresponding Pfam domain ("Al-2E_transport"). 
bioRxiv preprint doi: https://doi.org/10.1101/2021.11.19.469292; this version posted November 20, 2021. The copyright holder for this preprint (which was not certified by peer review) is the author/funder, who has granted bioRxiv a license to display the preprint in perpetuity. It is made available under aCC-BY 4.0 International license.

The HMMs of TC \#2.A.86 and \#2.A.86.1 match from residues 444-866 of human TMEM245, which are the last $6 \mathrm{TMHs}$ according to UniProt predictions. The last $5 \mathrm{TMHs}$ are separated from the previous ones by a slightly larger loop. This architecture is similar to the $3+5$ arrangement of the previously described bacterial $\mathrm{Na}^{+}\left(\mathrm{Li}^{+}\right) / \mathrm{H}^{+}$antiporter TC \#2.A.86.1.14 according to UniProt predictions (accession code: NLHAP_HALAA). This bacterial protein also matched the full-length "AI2E_transport" domain from Pfam, while only the last 5 TMHs of TMEM245 match with C-terminal region of "Al-2E_transport". The human TMEM245 protein contains $14 \mathrm{TMHs}$ in total according to UniProt predictions. Thus, TMEM245 might have a transporter-like domain at the C-terminus. In terms of the structure, we have not found any similarities to proteins with known structure. Therefore both TMEM245 and bacterial exporters and antiporters in the TC \#2.A.86 family are likely to have a yet uncharacterized tertiary structure. Functionally, the TMEM245 protein also remains elusive.

The TMEM41A, TMEM41B, and TMEM64 proteins clustered to the same family in our results. These are the only proteins in human that show any similarity to the "SNARE_assoc" Pfam domain, as well as to the TCDB family \#9.B.27. While no protein with this domain or from this family has direct evidence for transport activity, Pfam reports SCOOP-based similarity [92] of the "SNARE_assoc" domain with "Sm_multidrug_ex", which is a domain encoding transporter proteins. Some members of the family in the TCDB have been proposed to be "cation:proton importers" (\#9.B.27.2.2) or "selenite transport proteins" (\#9.B.27.2.3).

The most well-characterized member of the human protein family is TMEM41B. Interestingly, a recent study reported a putative structure generated ab initio using evolutionary covariance-derived information [93]. Strikingly, this structural model shows features reminiscent of secondary transporters, such as a tandem internal repeat with two-fold rotational symmetry, and the authors suggest $\mathrm{H}^{+}$antiporter activity as a mechanism of transport [93].

While the exact function of TMEM41B is still unclear, it forms a complex with vacuole membrane protein 1 (VMP1), also harboring the "SNARE_assoc" domain, and both are required for autophagosome formation [94,95]. Tmem41b localized to mitochondria-associated ER membranes [96-98]. Interestingly, TMEM41B seems to be an absolutely required factor for SARS-CoV-2 [99], and probably also flaviviral [100] infection, possibly by facilitating a membrane curvature that is beneficial for viral replication [100].

The proteins TMEM184A, TMEM184B, TMEM184C clustered together with SLC51A (family of transporters of steroid-derived molecules) in our analysis. While human TMEM184B and SLC51A are included in the TCDB as members of family \#2.A.82, TMEM184A and C are not. Independently, the "Solute_trans_a" Pfam domain was found in all four proteins with high scores and significance, but not in other human proteins. Therefore, it is likely that the four proteins, TMEM184A-C and SLC51A, are homologous. In spite of this, sequence identity between TMEM184 proteins and SLC51A is low (12.3\%-13.6\%), but moderate among TMEM184 proteins (26.5\%-62.0\%). All four proteins are predicted to harbor 7 TM helices according to UniProt, yet our search has found no similar proteins with known structures.

TMEM184A was identified as a heparin receptor in vascular cells [101], but no transport activity has been reported. Interestingly, while SLC51A is known to function as a bile acid transporter [102-104], TMEM184B has been proposed to be responsible for ibuprofen uptake [105]. This is interesting in view of the partial chemical similarity between steroid acids and ibuprofen, both harboring a hydrophobic hydrocarbon part and a carboxyl moiety. TMEM184C resides in a locus that has been suggested to be responsible for the pathogenicity of X-linked congenital hypertrichosis syndrome [106], but no transport activity has been suggested. 
bioRxiv preprint doi: https://doi.org/10.1101/2021.11.19.469292; this version posted November 20, 2021. The copyright holder for this preprint (which was not certified by peer review) is the author/funder, who has granted bioRxiv a license to display the preprint in perpetuity. It is made available under aCC-BY 4.0 International license.

\section{Putative transporters}

Our search also identified proteins whose transport activity is either controversial or not characterized, and which do not show sequence similarity to transporters of known function. Thus, the proteins in these families require further investigation to uncover their function.

The CNNM1-4 proteins (also called ACDP1-4) are distant homologs of the cyclins, but have no documented enzymatic activity. Instead, CNNM proteins belong to a highly conserved family of $\mathrm{Mg}^{2+}$ transport-related proteins [107], and CNNM2 and CNNM4 have been proposed to be the long sought after basolateral $\mathrm{Na}^{+} / \mathrm{Mg}^{2+}$ exchangers in the kidney and intestine, respectively $[108,109]$. The function of these proteins is, however, controversial [110-113], and there are hypotheses that CNNM proteins per se are not $\mathrm{Mg}^{2+}$ transporters [114]. Most recently, however, the structure of a bacterial homolog, CorC, has been resolved, revealing its membrane topology, as well as a conserved $\mathrm{Mg}^{2+}$-binding site [115]. Strikingly, the $\mathrm{Mg}^{2+}$ ions in the structure are fully dehydrated, in contrast to those in other known $\mathrm{Mg}^{2+}$ channel structures [115], which makes it unlikely that the proteins function via a channel-like transport mechanism. In line with this, the authors suggest an alternatingaccess exchange mechanism [115], however, further studies are required to understand how and whether CNNM proteins might be able to mediate the translocation of $\mathrm{Mg}^{2+}$ ions across the membrane.

A family of 4 lysosomal-associated transmembrane proteins (LAPTM4A, LAPTM4B, LAPTM5 and sequence B4EOC1) turned up in our search, corresponding to the TCDB subfamily \#2.A.74.1 and Pfam domain "Mtp" (mouse transporter protein). The family also includes an uncharacterized transcript with the UniProt accession "B4EOC1". Originally, the mouse transporter protein (Mtp, ortholog of LAPTM4A) was characterized as a transporter mediating the transport of nucleosides and nucleobases between the cytoplasm and intracellular compartments [116], and was later also associated with multidrug-resistance (MDR) in yeast, where its expression changed the subcellular compartmentalization of a heterogenous group of compounds $[117,118]$. LAPTM4A was shown to be involved in glycosylation and glycolipid regulation $[119,120]$. All three proteins seem to be lysosomal $[116,121,122]$. Nevertheless, these proteins appear to interact with other characterized transporters, such as SLC22A2 (hOCT2), SLC7A5/SLC3A2 (LAT1/4F2hc) and MDR-related ABC transporters [123-125]. But it has been claimed that they are not per se transporters, but rather regulatory factors, either assisting the localization and targeting or the function of other transporters [125]. Interestingly, the transcript "B4EOC1" appears to have $4 \mathrm{TMHs}$ at its N-terminus, which is identical to human LAPTM5 apart from a 40-amino acid insertion between TMH3 and TMH4. This region also shows significant similarity to both the "Mtp" Pfam domain and the TC \#2.A.74.1 subfamily. However, the C-terminal region of the transcript is identical to the C-terminal segment of "actin filament-associated protein 1-like 1" protein (UniProt accession Q8TED9). We did not find any similar fusion sequences in the other organisms we analyzed. The "Mtp" Pfam domain, which is the hallmark of the family, belongs to the "Tetraspannin" Pfam clan, which has no other domains with annotated transporter function and no similarity to existing transporters. Structural information is also not available. Therefore, the transport function of these proteins requires further investigation.

Our search identified four proteins in human (LMBR1, LMBR1L, LMBD1/LMBRD1, LMBRD2) bearing the "LMBR1" Pfam domain, which clustered into two families in our analysis. These proteins correspond to TCDB family \#9.A.54. The LMBD1 protein, encoded by the LMBRD1 gene, was suggested to function as a vitamin B12 (cobalamin) transporter, exporting vitamin B12 from the lysosomes into the cytoplasm [126]. However, it was later shown that LMBD1 actually interacts with $A B C D 4$ and assists in its lysosomal trafficking [127], and that $A B C D 4$ transports vitamin $B 12$ even in the absence of LMBD1 [128]. Therefore, it is likely that LMBD1 itself is not a vitamin B12 transporter. LMBD1 was originally coined as having "significant homology" to lipocalin membrane receptors [126], and indeed the LIMR (lipocalin-1-interacting membrane receptor) protein, encoded by the LMBR1L gene, is responsible for binding lipocain 1 (LCN-1) with high affinity $[129,130]$. LMBRD2 was 
bioRxiv preprint doi: https://doi.org/10.1101/2021.11.19.469292; this version posted November 20, 2021. The copyright holder for this preprint (which was not certified by peer review) is the author/funder, who has granted bioRxiv a license to display the preprint in perpetuity. It is made available under aCC-BY 4.0 International license.

proposed to be a regulator of $\beta 2$-adrenoceptor signaling [131], while the first protein identified in the family, LMBR1, was associated with polydactyly and limb malformations $[132,133]$. However, its physiological role is still elusive. The proteins seem to contain $9 \mathrm{TMHs}$ in a $5+4$ arrangement according to UniProt predictions, but the tertiary structure of the proteins is still unknown, and no homologs with a known structure were found in our search.

Two MagT1-like proteins (MAGT1 and TUSC3), as well as OSTC and OSTCL (oligosaccharyltransferase complex subunit) turned up in our search, showing similarity to TCDB family \#1.A.76 members. MAGT1 and TUSC3 also have high-scoring hits for the Pfam domain "OST3_OST6", which is characteristic of members of the oligosaccharyltransferase (OST) complex. TUSC3 (also called N33) was first identified as a tumor suppressor gene [134], and its presence, together with that of MAGT1 in the OST complex has been attested later on [135-139]. Therefore, it was suggested that these proteins act as oxidoreductases [138]. Meanwhile, MAGT1 and TUSC3 were also proposed to act as $\mathrm{Mg}^{2+}$ transporters [140,141]. On the other hand, recent structural findings of human MAGT1 [139] indicated that this protein may not function as a transporter or channel due to the lack of substratebinding site or pore. OSTC (also called DC2) has similarly been shown to be part of the OST complex and to have a structure similar to MAGT1 [139]. Whether MagT1-like proteins still have a transport function remains to be clarified.

The TMEM14A, TMEM14B and TMEM14C proteins are the only ones in human containing the "Tmemb_14" Pfam domain. While Pfam lists this domain as functionally uncharacterized, a plant protein (FAX1) containing this domain was suggested to be involved in fatty acid export from chloroplasts [142]. However, the physiological roles of TMEM14A and TMEM14B in human remain elusive. The third member of the family, TMEM14C, was identified as a putative mitochondrial protein whose transcript is consistently coexpressed with proteins from the core machinery of heme biosynthesis [143]. It was later shown that TMEM14C mediates the import of protoporphyrinogen IX (PPgenIX) into the mitochondrial matrix [144,145]. While the structure of TMEM14C was solved using nuclear magnetic resonance (NMR) [146], showing a bundle of three TM helices and an amphipathic helix, the transport mechanism remains elusive. Interestingly, despite their proposed function in the mitochondria, TargetP-2.0 [147] did not predict a mitochondrial targeting sequence in the amino acid sequence of any of the human TMEM14 proteins in our hands.

TMEM205 is a 4-TMH protein according to UniProt annotations, which was linked to cisplatin resistance [148]. The protein is expressed mostly in liver, pancreas and adrenal glands, and is present on the plasma membrane [148]. TMEM205-mediated resistance was shown to be selective towards platinum-based drugs, such as cisplatin and oxaliplatin, but not carboplatin [149]. While structural information about the protein is not available, mutagenesis studies of TMEM205 showed that mutating sulfur-containing residues, especially in $\mathrm{TMH} 2$ and $\mathrm{TMH} 4$, diminishes the effect of cisplatin resistance [149]. Nevertheless, neither the biological function nor the physiological substrates of TMEM205 are known.

\section{Transporters with hydrophobic substrates}

In addition to proteins that transport solutes or are similar to transporters that typically translocate water-soluble small molecule compounds, our search has uncovered numerous proteins that have been reported to take part in modulating the intracellular distribution of hydrophobic or amphipathic compounds, such as cholesterol, fat-soluble vitamins, lipids and fatty acids (Table 3). Although these proteins do not, strictly speaking, transport so-called "solutes", they translocate small hydrophobic molecules that have fundamental biological functions. Thus they belong to the SLC superfamily as well. Accordingly, they have been integrated in our search and some of them have already been included in the SLC nomenclature (SLC59, SLC63, SLC65). In view of the biological and pharmaceutical importance of the transport mechanisms of hydrophobic substrates, our results on this topic will be discussed in a separate paper. 
bioRxiv preprint doi: https://doi.org/10.1101/2021.11.19.469292; this version posted November 20, 2021. The copyright holder for this preprint (which was not certified by peer review) is the author/funder, who has granted bioRxiv a license to display the preprint in perpetuity. It is made available under aCC-BY 4.0 International license.

\section{Conclusions}

Our study represents the first systematic correlation of the SLC and TCDB nomenclature schemes. Many of the transport proteins discovered in our search are underexplored and there is limited information about them, although they often have important physiological roles and/or potentially represent new therapeutic targets. Even with proteins that have been studied for their physiological involvement, it was often not taken into account that they could have a transport function. Numerous proteins uncovered in our search have similarity to proteins with transport function in other organisms, but their physiological substrates remain unknown. These proteins will be interesting targets for deorphanization studies, to reveal their natural substrates. In our work, we also highlight proteins for which transport activity has been controversial, and more specific analyses are required to clarify their biological function. In addition, our search reveals new SLC-like proteins that have no structural information. This hinders a deeper understanding of their transport mechanism. Future structure determinations would be of crucial importance to accelerate validation of the identified proteins. The combination of all these efforts would greatly facilitate the completion of the SLC-ome in human cells. Thus, our study points out important directions in which future studies could help resolve the lack of information about SLC transporters, which will help unlock their therapeutic potential.

\section{Acknowledgements}

We acknowledge support by the Swiss National Science Foundation for the grants \# CRSII5_180326 ("The role of mitochondrial carriers in metabolic tuning and reprogramming by calcium flow across membrane contact sites") and \# 310030_182272 ("Intestinal absorption of transition metals in human health and disease") as well as by the Swiss National Research Programme NRP 78, \# 4078P0_198281 ("New insights into the COVID-19 pandemic"). Calculations were performed on UBELIX (http://www.id.unibe.ch/hpc), the HPC cluster at the University of Bern.

\section{Methods}

\section{Transmembrane segment prediction}

In certain cases, especially with less well-characterized putative transporters of the TC\# 9.A and 9.B superfamilies, transmembrane helix prediction based on HMMTOP [150] was used to assess the number of transmembrane helices.

\section{HMM building for TCDB families and subfamilies}

Sequences of selected TCDB families and subfamilies were aligned using PSI-Coffee 11.00 [151] and NCBI BLAST+ 2.6.0 [152] using the "nr" BLAST database of 2018-02-12. The alignments were turned into HMMs using the "hmmbuild" command of HMMER 3.1b2 [30] using default settings.

\section{Sequence similarity search}

All protein belonging to each of the 7 organisms studied were downloaded from UniProt into a FASTA file. Sequence similarity search was performed using the HMMs downloaded for selected Pfam families and those generated for selected TCDB families and subfamilies using "hmmsearch" from HMMER 3.1b2. Hits with bit scores larger than 50 were used for further analysis.

\section{Sequence clustering for fragment elimination}

Since the downloaded protein set from UniProt contained fragments as well as predicted open reading frames and sequences from genomic screening methods, we strived to retain one sequence per gene for further analysis. In order to achieve this, hits yielded by the sequence similarity search were clustered using the following method. First, all-against-all similarity searches were performed using NCBI BLAST+ 2.4.0 [152]. Sequences were assigned the same cluster if they either share common gene annotations according to their UniProt records, or a high-scoring segment pair (HSP) with more than $95 \%$ sequence identity based on the all-against-all BLAST search. For gene 
bioRxiv preprint doi: https://doi.org/10.1101/2021.11.19.469292; this version posted November 20, 2021. The copyright holder for this preprint (which was not certified by peer review) is the author/funder, who has granted bioRxiv a license to display the preprint in perpetuity. It is made available under aCC-BY 4.0 International license.

annotation, the fields Gene Symbol (GN), HGNC symbol, GenelD, UniGene, FlyBase, KEGG identifiers were used from UniProt records. Ambiguous or conflicting annotations, as well as annotations conflicting with BLAST-reported sequence similarity were detected and resolved manually. Afterwards, clusters were reduced to representative sequences. For clusters containing a single Swiss-Prot sequence, that sequence was taken as representative. For cluster with no Swiss-Prot sequence, the longest sequence of the cluster was taken as representative. Clusters with more than one Swiss-Prot sequence were manually analyzed and split if necessary.

\section{HMM fingerprint-based sequence clustering}

We introduce the concept of a "HMM fingerprint", which is a mathematical vector of numbers assigned to a protein sequence, corresponding to the bit scores of similarity to each of the set of HMMs used in our analysis, consisting of the HMMs of TCDB families and subfamilies, as well as Pfam HMMs. We have restricted the number of HMMs to those that gave a hit with bit score $>25$, in total $513 \mathrm{HMMs}$. Two proteins sequences that are related are expected to show similarity to a similar subset of TCDB families, subfamilies, or Pfam families, and therefore a similar pattern in their HMM fingerprints. In turn, if two protein sequences show similarity to the same subset of TCDB families, subfamilies or Pfam families, as indicated by a similar HMM fingerprint, then they can be expected to be related. Once the HMM fingerprint has been assigned to each protein sequence found in our search, the unweighted pair group method with arithmetic mean (UPGMA) method [SokalMichener1958] was used using the cosine metric to arrive at a hierarchical clustering of the sequences. The tree representing the clustering was cut at 0.7 cosine distance to arrive at branches that formed the basis of protein families. For some families, the threshold was either elevated to join outlier sequences (SLC5A7, SLC10A7, SLC25A46, SLC30A9, SLC39A9, MPDU1/SLC66A5, SLC9B subfamily, SLC35 subfamilies) or reduced to separate highly similar families (SLC32-36-38, SLC2-22, SLC17-18-37).

\section{Structural search}

Sequences of SLC-like proteins were turned into HMMs using "hhblits" from the HH-suite3 package [153], using the UniRef30 database of 2020-06 [154,155], 3 iterations, an E-value threshold of 1e-3 for inclusion, and a probability threshold of 0.35 for MAC re-alignment. The HMMs were searched against the "pdb70" database of 2021-08-04 [154] with no MAC realignment, "predicted vs predicted" secondary structure scoring, and amino acid score of 1 . The resulting hits were checked against PDB annotations of transmembrane helices, and were accepted if at least 3 TM segments were contained within the aligned region and the E-value of the hit was less than 1e-4.

\section{Phylogenetic trees}

Selected groups of SLC-like proteins were aligned using Clustal Omega 1.2.1 $[156,157]$ with 5 iterations and default settings. Smart Model Selection 1.8.4 [158] and PhyML 3.3.20190909 [159] were used to generate the phylogenetic trees, with 10 random starting trees and using the approximate likelihood ratio test aLRT method [160]. Trees in main figures were visualized using TreeViewer 1.2.2 [https://treeviewer.org/]. Tree rooting, rearrangement (with threshold 0.9) and reconciliation with the species tree was done using NOTUNG 2.9.1.5 [161]. Reconciled phylogenetic trees were visualized using custom Python scripts in the style used by NOTUNG. Orthologs were identified using the reconciled phylogenetic trees and custom Python scripts.

\section{References}

1. Hediger MA, Clémençon B, Burrier RE, Bruford EA. The ABCs of membrane transporters in health and disease (SLC series): introduction. Mol Aspects Med. 2013;34: 95-107. doi:10.1016/j.mam.2012.12.009

2. César-Razquin A, Snijder B, Frappier-Brinton T, Isserlin R, Gyimesi G, Bai X, et al. A Call for Systematic Research on Solute Carriers. Cell. 2015;162: 478-487. doi:10.1016/j.cell.2015.07.022 
3. Hediger MA, Romero MF, Peng J-B, Rolfs A, Takanaga H, Bruford EA. The ABCs of solute carriers: physiological, pathological and therapeutic implications of human membrane transport proteinsIntroduction. Pflugers Arch. 2004;447: 465-468. doi:10.1007/s00424-003-1192-y

4. Bai X, Moraes TF, Reithmeier RAF. Structural biology of solute carrier (SLC) membrane transport proteins. Mol Membr Biol. 2018; 1-32. doi:10.1080/09687688.2018.1448123

5. Choi S, Jeon J, Yang J-S, Kim S. Common occurrence of internal repeat symmetry in membrane proteins. Proteins. 2008;71: 68-80. doi:10.1002/prot.21656

6. Forrest LR. Structural Symmetry in Membrane Proteins. Annu Rev Biophys. 2015;44: 311337. doi:10.1146/annurev-biophys-051013-023008

7. Jardetzky O. Simple allosteric model for membrane pumps. Nature. 1966;211: 969-970. doi:10.1038/211969a0

8. Forrest $L R$, Krämer $R$, Ziegler $C$. The structural basis of secondary active transport mechanisms. Biochim Biophys Acta. 2011;1807: 167-188. doi:10.1016/j.bbabio.2010.10.014

9. Fredriksson R, Nordström KJV, Stephansson O, Hägglund MGA, Schiöth HB. The solute carrier (SLC) complement of the human genome: phylogenetic classification reveals four major families. FEBS Lett. 2008;582: 3811-3816. doi:10.1016/j.febslet.2008.10.016

10. Perland E, Fredriksson R. Classification Systems of Secondary Active Transporters. Trends Pharmacol Sci. 2017;38: 305-315. doi:10.1016/j.tips.2016.11.008

11. Perland E, Bagchi S, Klaesson A, Fredriksson R. Characteristics of 29 novel atypical solute carriers of major facilitator superfamily type: evolutionary conservation, predicted structure and neuronal co-expression. Open Biol. 2017;7. doi:10.1098/rsob.170142

12. Schlessinger A, Matsson P, Shima JE, Pieper U, Yee SW, Kelly L, et al. Comparison of human solute carriers. Protein Science. 2010;19: 412-428. doi:10.1002/pro.320

13. Schlessinger A, Yee SW, Sali A, Giacomini KM. SLC classification: an update. Clin Pharmacol Ther. 2013;94: 19-23. doi:10.1038/clpt.2013.73

14. Saier MH. Molecular phylogeny as a basis for the classification of transport proteins from bacteria, archaea and eukarya. Adv Microb Physiol. 1998;40: 81-136.

15. Saier MH, Reddy VS, Moreno-Hagelsieb G, Hendargo KJ, Zhang Y, Iddamsetty V, et al. The Transporter Classification Database (TCDB): 2021 update. Nucleic Acids Res. 2021;49: D461-D467. doi:10.1093/nar/gkaa1004

16. Cao Y, Jin X, Huang H, Derebe MG, Levin EJ, Kabaleeswaran V, et al. Crystal structure of a potassium ion transporter, TrkH. Nature. 2011;471: 336-340. doi:10.1038/nature09731

17. Bosson R, Jaquenoud M, Conzelmann A. GUP1 of Saccharomyces cerevisiae encodes an Oacyltransferase involved in remodeling of the GPI anchor. Mol Biol Cell. 2006;17: 2636-2645.

doi:10.1091/mbc.e06-02-0104

18. Berks BC, Sargent F, Palmer T. The Tat protein export pathway. Mol Microbiol. 2000;35: 260-274. doi:10.1046/j.1365-2958.2000.01719.x

19. Berks BC, Sargent F, De Leeuw E, Hinsley AP, Stanley NR, Jack RL, et al. A novel protein transport system involved in the biogenesis of bacterial electron transfer chains. Biochim Biophys Acta. 2000;1459: 325-330. doi:10.1016/s0005-2728(00)00168-7

20. Ren Q, Kang KH, Paulsen IT. TransportDB: a relational database of cellular membrane transport systems. Nucleic Acids Res. 2004;32: D284-288. doi:10.1093/nar/gkh016

21. Ren Q, Chen K, Paulsen IT. TransportDB: a comprehensive database resource for cytoplasmic membrane transport systems and outer membrane channels. Nucleic Acids Res. 2007;35: D274-279. doi:10.1093/nar/gk1925

22. Elbourne LDH, Tetu SG, Hassan KA, Paulsen IT. TransportDB 2.0: a database for exploring membrane transporters in sequenced genomes from all domains of life. Nucleic Acids Res. 2017;45: D320-D324. doi:10.1093/nar/gkw1068

23. Tatusov RL, Natale DA, Garkavtsev IV, Tatusova TA, Shankavaram UT, Rao BS, et al. The COG database: new developments in phylogenetic classification of proteins from complete genomes.

Nucleic Acids Res. 2001;29: 22-28. doi:10.1093/nar/29.1.22 
bioRxiv preprint doi: https://doi.org/10.1101/2021.11.19.469292; this version posted November 20, 2021. The copyright holder for this preprint (which was not certified by peer review) is the author/funder, who has granted bioRxiv a license to display the preprint in perpetuity. It is made available under aCC-BY 4.0 International license.

24. Haft DH, Selengut JD, Richter RA, Harkins D, Basu MK, Beck E. TIGRFAMs and Genome Properties in 2013. Nucleic Acids Res. 2013;41: D387-395. doi:10.1093/nar/gks1234

25. Finn RD, Coggill P, Eberhardt RY, Eddy SR, Mistry J, Mitchell AL, et al. The Pfam protein families database: towards a more sustainable future. Nucleic Acids Res. 2016;44: D279-285. doi:10.1093/nar/gkv1344

26. Krogh A, Larsson B, von Heijne G, Sonnhammer EL. Predicting transmembrane protein topology with a hidden Markov model: application to complete genomes. J Mol Biol. 2001;305: 567580. doi:10.1006/jmbi.2000.4315

27. UniProt Consortium. UniProt: a worldwide hub of protein knowledge. Nucleic Acids Res. 2019;47: D506-D515. doi:10.1093/nar/gky1049

28. El-Gebali S, Mistry J, Bateman A, Eddy SR, Luciani A, Potter SC, et al. The Pfam protein families database in 2019. Nucleic Acids Res. 2019;47: D427-D432. doi:10.1093/nar/gky995

29. Finn RD, Mistry J, Schuster-Böckler B, Griffiths-Jones S, Hollich V, Lassmann T, et al. Pfam:

clans, web tools and services. Nucleic Acids Res. 2006;34: D247-251. doi:10.1093/nar/gkj149

30. Eddy SR. Accelerated Profile HMM Searches. PLoS Comput Biol. 2011;7: e1002195. doi:10.1371/journal.pcbi.1002195

31. Boutet E, Lieberherr D, Tognolli M, Schneider M, Bairoch A. UniProtKB/Swiss-Prot. Methods Mol Biol. 2007;406: 89-112. doi:10.1007/978-1-59745-535-0_4

32. Gyimesi G, Hediger MA. Sequence Features of Mitochondrial Transporter Protein Families. Biomolecules. 2020;10. doi:10.3390/biom10121611

33. Horiba N, Masuda S, Takeuchi A, Takeuchi D, Okuda M, Inui K. Cloning and characterization of a novel Na+-dependent glucose transporter (NaGLT1) in rat kidney. J Biol Chem. 2003;278:

14669-14676. doi:10.1074/jbc.M212240200

34. Nawata CM, Dantzler WH, Pannabecker TL. Alternative channels for urea in the inner medulla of the rat kidney. Am J Physiol Renal Physiol. 2015;309: F916-924.

doi:10.1152/ajprenal.00392.2015

35. Tejada-Jiménez M, Galván A, Fernández E. Algae and humans share a molybdate transporter. Proc Natl Acad Sci USA. 2011;108: 6420-6425. doi:10.1073/pnas.1100700108

36. Zhu W, Spiga L, Winter S. Transition metals and host-microbe interactions in the inflamed intestine. Biometals. 2019;32: 369-384. doi:10.1007/s10534-019-00182-8

37. Barth J, Zimmermann H, Volknandt W. SV31 is a Zn2+-binding synaptic vesicle protein. J Neurochem. 2011;118: 558-570. doi:10.1111/j.1471-4159.2011.07344.x

38. Waberer L, Henrich E, Peetz O, Morgner N, Dötsch V, Bernhard F, et al. The synaptic vesicle protein SV31 assembles into a dimer and transports Zn2. J Neurochem. 2017;140: 280-293.

doi:10.1111/jnc.13886

39. Cuajungco MP, Kiselyov K. The mucolipin-1 (TRPML1) ion channel, transmembrane-163

(TMEM163) protein, and lysosomal zinc handling. Front Biosci (Landmark Ed). 2017;22: 1330-1343.

40. Sanchez VB, Ali S, Escobar A, Cuajungco MP. Transmembrane 163 (TMEM163) protein effluxes zinc. Arch Biochem Biophys. 2019;677: 108166. doi:10.1016/j.abb.2019.108166

41. Burré J, Zimmermann $\mathrm{H}$, Volknandt W. Identification and characterization of SV31, a novel synaptic vesicle membrane protein and potential transporter. J Neurochem. 2007;103: 276-287. doi:10.1111/j.1471-4159.2007.04758.x

42. Wang L, Li N-N, Lu Z-J, Li J-Y, Peng J-X, Duan L-R, et al. Association of three candidate genetic variants in ACMSD/TMEM163, GPNMB and BCKDK /STX1B with sporadic Parkinson's disease in Han Chinese. Neurosci Lett. 2019;703: 45-48. doi:10.1016/j.neulet.2019.03.019

43. Chang K-H, Chen C-M, Chen Y-C, Fung H-C, Wu Y-R. Polymorphisms of ACMSD-TMEM163, MCCC1, and BCKDK-STX1B Are Not Associated with Parkinson's Disease in Taiwan. Parkinsons Dis. 2019;2019: 3489638. doi:10.1155/2019/3489638

44. Lauterbach EC. Psychotropic drug effects on gene transcriptomics relevant to Parkinson's disease. Prog Neuropsychopharmacol Biol Psychiatry. 2012;38: 107-115.

doi:10.1016/j.pnpbp.2012.03.011 
bioRxiv preprint doi: https://doi.org/10.1101/2021.11.19.469292; this version posted November 20, 2021. The copyright holder for this preprint (which was not certified by peer review) is the author/funder, who has granted bioRxiv a license to display the preprint in perpetuity. It is made available under aCC-BY 4.0 International license.

45. Chakraborty S, Vellarikkal SK, Sivasubbu S, Roy SS, Tandon N, Bharadwaj D. Role of Tmem163 in zinc-regulated insulin storage of MIN6 cells: Functional exploration of an Indian type 2 diabetes GWAS associated gene. Biochem Biophys Res Commun. 2019. doi:10.1016/j.bbrc.2019.11.117 46. Tabassum R, Chauhan G, Dwivedi OP, Mahajan A, Jaiswal A, Kaur I, et al. Genome-wide association study for type 2 diabetes in Indians identifies a new susceptibility locus at 2 q21. Diabetes. 2013;62: 977-986. doi:10.2337/db12-0406

47. Bai H, Liu H, Suyalatu S, Guo X, Chu S, Chen Y, et al. Association Analysis of Genetic Variants with Type 2 Diabetes in a Mongolian Population in China. J Diabetes Res. 2015;2015: 613236. doi:10.1155/2015/613236

48. Foulquier F, Amyere M, Jaeken J, Zeevaert R, Schollen E, Race V, et al. TMEM165 deficiency causes a congenital disorder of glycosylation. Am J Hum Genet. 2012;91: 15-26.

doi:10.1016/j.ajhg.2012.05.002

49. Demaegd D, Foulquier F, Colinet A-S, Gremillon L, Legrand D, Mariot P, et al. Newly characterized Golgi-localized family of proteins is involved in calcium and $\mathrm{pH}$ homeostasis in yeast and human cells. Proc Natl Acad Sci USA. 2013;110: 6859-6864. doi:10.1073/pnas.1219871110 50. Foulquier F, Legrand D. Biometals and glycosylation in humans: Congenital disorders of glycosylation shed lights into the crucial role of Golgi manganese homeostasis. Biochim Biophys Acta Gen Subj. 2020;1864: 129674. doi:10.1016/j.bbagen.2020.129674

51. Stribny J, Thines L, Deschamps A, Goffin P, Morsomme P. The human Golgi protein TMEM165 transports calcium and manganese in yeast and bacterial cells. J Biol Chem. 2020;295: 3865-3874. doi:10.1074/jbc.RA119.012249

52. Snyder NA, Palmer MV, Reinhardt TA, Cunningham KW. Milk biosynthesis requires the Golgi cation exchanger TMEM165. J Biol Chem. 2019;294: 3181-3191. doi:10.1074/jbc.RA118.006270 53. Reinhardt TA, Lippolis JD, Sacco RE. The $\mathrm{Ca}(2+) / \mathrm{H}(+)$ antiporter TMEM165 expression, localization in the developing, lactating and involuting mammary gland parallels the secretory pathway $\mathrm{Ca}(2+)$ ATPase (SPCA1). Biochem Biophys Res Commun. 2014;445: 417-421. doi:10.1016/j.bbrc.2014.02.020

54. Lebredonchel E, Houdou M, Potelle S, de Bettignies G, Schulz C, Krzewinski Recchi M-A, et al. Dissection of TMEM165 function in Golgi glycosylation and its Mn2+ sensitivity. Biochimie. 2019;165: 123-130. doi:10.1016/j.biochi.2019.07.016

55. Perland E, Lekholm E, Eriksson MM, Bagchi S, Arapi V, Fredriksson R. The Putative SLC Transporters Mfsd5 and Mfsd11 Are Abundantly Expressed in the Mouse Brain and Have a Potential Role in Energy Homeostasis. PLOS ONE. 2016;11: e0156912. doi:10.1371/journal.pone.0156912 56. Lekholm E, Perland E, Eriksson MM, Hellsten SV, Lindberg FA, Rostami J, et al. Putative Membrane-Bound Transporters MFSD14A and MFSD14B Are Neuronal and Affected by Nutrient Availability. Front Mol Neurosci. 2017;10: 11. doi:10.3389/fnmol.2017.00011

57. Perland E, Hellsten SV, Lekholm E, Eriksson MM, Arapi V, Fredriksson R. The Novel Membrane-Bound Proteins MFSD1 and MFSD3 are Putative SLC Transporters Affected by Altered Nutrient Intake. J Mol Neurosci. 2017;61: 199-214. doi:10.1007/s12031-016-0867-8

58. Bagchi S, Perland E, Hosseini K, Lundgren J, Al-Walai N, Kheder S, et al. Probable role for major facilitator superfamily domain containing 6 (MFSD6) in the brain during variable energy consumption. Int J Neurosci. 2020;130: 476-489. doi:10.1080/00207454.2019.1694020 59. Valoskova K, Biebl J, Roblek M, Emtenani S, Gyoergy A, Misova M, et al. A conserved major facilitator superfamily member orchestrates a subset of O-glycosylation to aid macrophage tissue invasion. Elife. 2019;8. doi:10.7554/eLife.41801

60. Landis GN, Bhole D, Tower J. A search for doxycycline-dependent mutations that increase Drosophila melanogaster life span identifies the VhaSFD, Sugar baby, filamin, fwd and Cctl genes. Genome Biol. 2003;4: R8. doi:10.1186/gb-2003-4-2-r8

61. Kim KW, Tang NH, Piggott CA, Andrusiak MG, Park S, Zhu M, et al. Expanded genetic screening in Caenorhabditis elegans identifies new regulators and an inhibitory role for NAD+ in axon regeneration. Elife. 2018;7: e39756. doi:10.7554/eLife.39756 
bioRxiv preprint doi: https://doi.org/10.1101/2021.11.19.469292; this version posted November 20, 2021. The copyright holder for this preprint (which was not certified by peer review) is the author/funder, who has granted bioRxiv a license to display the preprint in perpetuity. It is made available under aCC-BY 4.0 International license.

62. Ceder MM, Aggarwal T, Hosseini K, Maturi V, Patil S, Perland E, et al. CG4928 Is Vital for Renal Function in Fruit Flies and Membrane Potential in Cells: A First In-Depth Characterization of the Putative Solute Carrier UNC93A. Front Cell Dev Biol. 2020;8: 580291.

doi:10.3389/fcell.2020.580291

63. Hannes F, Hammond P, Quarrell O, Fryns J-P, Devriendt K, Vermeesch JR. A microdeletion proximal of the critical deletion region is associated with mild Wolf-Hirschhorn syndrome. Am J Med Genet A. 2012;158A: 996-1004. doi:10.1002/ajmg.a.35299

64. Damme M, Brandenstein L, Fehr S, Jankowiak W, Bartsch U, Schweizer M, et al. Gene disruption of Mfsd8 in mice provides the first animal model for CLN7 disease. Neurobiol Dis. 2014;65: 12-24. doi:10.1016/j.nbd.2014.01.003

65. Siintola E, Topcu M, Aula N, Lohi H, Minassian BA, Paterson AD, et al. The novel neuronal ceroid lipofuscinosis gene MFSD8 encodes a putative lysosomal transporter. Am J Hum Genet. 2007;81: 136-146. doi:10.1086/518902

66. von Kleist L, Ariunbat K, Braren I, Stauber T, Storch S, Danyukova T. A newly generated neuronal cell model of CLN7 disease reveals aberrant lysosome motility and impaired cell survival. Mol Genet Metab. 2019;126: 196-205. doi:10.1016/j.ymgme.2018.09.009

67. Li Y, Yang X, Yang J, Wang H, Wei W. An 11-gene-based prognostic signature for uveal melanoma metastasis based on gene expression and DNA methylation profile. J Cell Biochem. 2018. doi:10.1002/jcb.28151

68. Nicoletti CF, Pinhel MS, Noronha NY, Jácome A, Crujeiras AB, Nonino CB. Association of MFSD3 promoter methylation level and weight regain after gastric bypass: Assessment for 3 y after surgery. Nutrition. 2020;70: 110499. doi:10.1016/j.nut.2019.04.010

69. Song Z. Roles of the nucleotide sugar transporters (SLC35 family) in health and disease. Mol Aspects Med. 2013;34: 590-600. doi:10.1016/j.mam.2012.12.004

70. Västermark $\AA$, Almén MS, Simmen MW, Fredriksson R, Schiöth HB. Functional specialization in nucleotide sugar transporters occurred through differentiation of the gene cluster EamA (DUF6) before the radiation of Viridiplantae. BMC Evol Biol. 2011;11: 123. doi:10.1186/1471-2148-11-123 71. Do DN, Schenkel FS, Miglior F, Zhao X, Ibeagha-Awemu EM. Genome wide association study identifies novel potential candidate genes for bovine milk cholesterol content. Sci Rep. 2018;8: 13239. doi:10.1038/s41598-018-31427-0

72. Prentice LM, d'Anglemont de Tassigny X, McKinney S, Ruiz de Algara T, Yap D, Turashvili G, et al. The testosterone-dependent and independent transcriptional networks in the hypothalamus of Gpr54 and Kiss1 knockout male mice are not fully equivalent. BMC Genomics. 2011;12: 209.

doi:10.1186/1471-2164-12-209

73. Rodriguez PQ, Oddsson A, Ebarasi L, He B, Hultenby K, Wernerson A, et al. Knockdown of Tmem234 in zebrafish results in proteinuria. Am J Physiol Renal Physiol. 2015;309: F955-966. doi:10.1152/ajprenal.00525.2014

74. Dean N, Zhang YB, Poster JB. The VRG4 gene is required for GDP-mannose transport into the lumen of the Golgi in the yeast, Saccharomyces cerevisiae. J Biol Chem. 1997;272: 31908-31914. doi:10.1074/jbc.272.50.31908

75. Baldwin TC, Handford MG, Yuseff MI, Orellana A, Dupree P. Identification and characterization of GONST1, a golgi-localized GDP-mannose transporter in Arabidopsis. Plant Cell. 2001;13: 2283-2295. doi:10.1105/tpc.010247

76. Rodríguez A, Gonzalez L, Ko A, Alvarez M, Miao Z, Bhagat Y, et al. Molecular Characterization of the Lipid Genome-Wide Association Study Signal on Chromosome 18q11.2 Implicates HNF4AMediated Regulation of the TMEM241 Gene. Arterioscler Thromb Vasc Biol. 2016;36: 1350-1355. doi:10.1161/ATVBAHA.116.307182

77. Trifonov S, Houtani T, Shimizu J-I, Hamada S, Kase M, Maruyama M, et al. GPR155: Gene organization, multiple mRNA splice variants and expression in mouse central nervous system. Biochem Biophys Res Commun. 2010;398: 19-25. doi:10.1016/j.bbrc.2010.05.162 
bioRxiv preprint doi: https://doi.org/10.1101/2021.11.19.469292; this version posted November 20, 2021. The copyright holder for this preprint (which was not certified by peer review) is the author/funder, who has granted bioRxiv a license to display the preprint in perpetuity. It is made available under aCC-BY 4.0 International license.

78. Wang XC, Liu Z, Jin LH. Anchor negatively regulates BMP signalling to control Drosophila wing development. Eur J Cell Biol. 2018;97: 308-317. doi:10.1016/j.ejcb.2018.04.007

79. Shimizu D, Kanda M, Tanaka H, Kobayashi D, Tanaka C, Hayashi M, et al. GPR155 Serves as a Predictive Biomarker for Hematogenous Metastasis in Patients with Gastric Cancer. Sci Rep. 2017;7: 42089. doi:10.1038/srep42089

80. Umeda S, Kanda M, Sugimoto H, Tanaka H, Hayashi M, Yamada S, et al. Downregulation of GPR155 as a prognostic factor after curative resection of hepatocellular carcinoma. BMC Cancer. 2017;17: 610. doi:10.1186/s12885-017-3629-2

81. Bräuer P, Parker JL, Gerondopoulos A, Zimmermann I, Seeger MA, Barr FA, et al. Structural basis for $\mathrm{pH}$-dependent retrieval of ER proteins from the Golgi by the KDEL receptor. Science.

2019;363: 1103-1107. doi:10.1126/science.aaw2859

82. Saudek V. Cystinosin, MPDU1, SWEETs and KDELR belong to a well-defined protein family with putative function of cargo receptors involved in vesicle trafficking. PLoS ONE. 2012;7: e30876. doi:10.1371/journal.pone.0030876

83. Helenius J, Ng DTW, Marolda CL, Walter P, Valvano MA, Aebi M. Translocation of lipid-linked oligosaccharides across the ER membrane requires Rft1 protein. Nature. 2002;415: 447-450. doi:10.1038/415447a

84. Frank CG, Sanyal S, Rush JS, Waechter CJ, Menon AK. Does Rft1 flip an N-glycan lipid precursor? Nature. 2008;454: E3-4; discussion E4-5. doi:10.1038/nature07165

85. Gottier P, Gonzalez-Salgado A, Menon AK, Liu Y-C, Acosta-Serrano A, Bütikofer P. RFT1 Protein Affects Glycosylphosphatidylinositol (GPI) Anchor Glycosylation. J Biol Chem. 2017;292: 1103-1111. doi:10.1074/jbc.M116.758367

86. Verchère $A$, Cowton $A$, Jenni A, Rauch $M$, Häner R, Graumann J, et al. Complexity of the eukaryotic dolichol-linked oligosaccharide scramblase suggested by activity correlation profiling mass spectrometry. Sci Rep. 2021;11: 1411. doi:10.1038/s41598-020-80956-0

87. Nobre LS, Al-Shahrour F, Dopazo J, Saraiva LM. Exploring the antimicrobial action of a carbon monoxide-releasing compound through whole-genome transcription profiling of Escherichia coli. Microbiology (Reading). 2009;155: 813-824. doi:10.1099/mic.0.023911-0

88. Herzberg M, Kaye IK, Peti W, Wood TK. YdgG (TqSA) controls biofilm formation in Escherichia coli K-12 through autoinducer 2 transport. J Bacteriol. 2006;188: 587-598.

doi:10.1128/JB.188.2.587-598.2006

89. Dong P, Wang L, Song N, Yang L, Chen J, Yan M, et al. A UPF0118 family protein with uncharacterized function from the moderate halophile Halobacillus andaensis represents a novel class of $\mathrm{Na}+(\mathrm{Li}+) / \mathrm{H}+$ antiporter. Sci Rep. 2017;7: 45936. doi:10.1038/srep45936

90. Wang L, Zou Q, Yan M, Wang Y, Guo S, Zhang R, et al. Polar or Charged Residues Located in Four Highly Conserved Motifs Play a Vital Role in the Function or pH Response of a UPF0118 Family $\mathrm{Na}+(\mathrm{Li}+) / \mathrm{H}+$ Antiporter. Front Microbiol. 2020;11: 841. doi:10.3389/fmicb.2020.00841

91. Shao L, Xu T, Zheng $\mathrm{X}$, Shao $\mathrm{D}$, Zhang $\mathrm{H}$, Chen $\mathrm{H}$, et al. A novel three-TMH $\mathrm{Na}+/ \mathrm{H}+$ antiporter and the functional role of its oligomerization. J Mol Biol. 2021;433: 166730.

doi:10.1016/j.jmb.2020.166730

92. Bateman A, Finn RD. SCOOP: a simple method for identification of novel protein superfamily relationships. Bioinformatics. 2007;23: 809-814. doi:10.1093/bioinformatics/btm034

93. Mesdaghi S, Murphy DL, Sánchez Rodríguez F, Burgos-Mármol JJ, Rigden DJ. In silico prediction of structure and function for a large family of transmembrane proteins that includes human Tmem41b. F1000Res. 2020;9: 1395. doi:10.12688/f1000research.27676.2

94. Morita K, Hama Y, Izume T, Tamura N, Ueno T, Yamashita Y, et al. Genome-wide CRISPR screen identifies TMEM41B as a gene required for autophagosome formation. J Cell Biol. 2018;217: 3817-3828. doi:10.1083/jcb.201804132

95. Moretti F, Bergman P, Dodgson S, Marcellin D, Claerr I, Goodwin JM, et al. TMEM41B is a novel regulator of autophagy and lipid mobilization. EMBO Rep. 2018;19.

doi:10.15252/embr.201845889 
bioRxiv preprint doi: https://doi.org/10.1101/2021.11.19.469292; this version posted November 20, 2021. The copyright holder for this preprint (which was not certified by peer review) is the author/funder, who has granted bioRxiv a license to display the preprint in perpetuity. It is made available under aCC-BY 4.0 International license.

96. Van Alstyne M, Lotti F, Dal Mas A, Area-Gomez E, Pellizzoni L. Stasimon/Tmem41b localizes to mitochondria-associated ER membranes and is essential for mouse embryonic development. Biochem Biophys Res Commun. 2018;506: 463-470. doi:10.1016/j.bbrc.2018.10.073

97. Morita K, Hama Y, Mizushima N. TMEM41B functions with VMP1 in autophagosome formation. Autophagy. 2019;15: 922-923. doi:10.1080/15548627.2019.1582952

98. Shoemaker CJ, Huang TQ, Weir NR, Polyakov NJ, Schultz SW, Denic V. CRISPR screening using an expanded toolkit of autophagy reporters identifies TMEM41B as a novel autophagy factor. PLoS Biol. 2019;17: e2007044. doi:10.1371/journal.pbio.2007044

99. Schneider WM, Luna JM, Hoffmann H-H, Sánchez-Rivera FJ, Leal AA, Ashbrook AW, et al. Genome-scale identification of SARS-CoV-2 and pan-coronavirus host factor networks. bioRxiv. 2020; 2020.10.07.326462. doi:10.1101/2020.10.07.326462

100. Hoffmann H-H, Schneider WM, Rozen-Gagnon K, Miles LA, Schuster F, Razooky B, et al. TMEM41B Is a Pan-flavivirus Host Factor. Cell. 2021;184: 133-148.e20.

doi:10.1016/j.cell.2020.12.005

101. Farwell SLN, Kanyi D, Hamel M, Slee JB, Miller EA, Cipolle MD, et al. Heparin Decreases in Tumor Necrosis Factor $\alpha$ (TNF $\alpha$ )-induced Endothelial Stress Responses Require Transmembrane Protein 184A and Induction of Dual Specificity Phosphatase 1. J Biol Chem. 2016;291: 5342-5354. doi:10.1074/jbc.M115.681288

102. Dawson PA, Hubbert M, Haywood J, Craddock AL, Zerangue N, Christian WV, et al. The heteromeric organic solute transporter alpha-beta, Ostalpha-Ostbeta, is an ileal basolateral bile acid transporter. J Biol Chem. 2005;280: 6960-6968. doi:10.1074/jbc.M412752200

103. Seward DJ, Koh AS, Boyer JL, Ballatori N. Functional complementation between a novel mammalian polygenic transport complex and an evolutionarily ancient organic solute transporter, OSTalpha-OSTbeta. J Biol Chem. 2003;278: 27473-27482. doi:10.1074/jbc.M301106200

104. Wang W, Seward DJ, Li L, Boyer JL, Ballatori N. Expression cloning of two genes that together mediate organic solute and steroid transport in the liver of a marine vertebrate. Proc Natl Acad Sci USA. 2001;98: 9431-9436. doi:10.1073/pnas.161099898

105. Rasmussen RN, Christensen KV, Holm R, Nielsen CU. Nfat5 is involved in the hyperosmotic regulation of Tmem184b: a putative modulator of ibuprofen transport in renal MDCK I cells. FEBS Open Bio. 2019;9: 1071-1081. doi:10.1002/2211-5463.12630

106. Zhu H, Shang D, Sun M, Choi S, Liu Q, Hao J, et al. X-linked congenital hypertrichosis syndrome is associated with interchromosomal insertions mediated by a human-specific palindrome near SOX3. Am J Hum Genet. 2011;88: 819-826. doi:10.1016/j.ajhg.2011.05.004

107. Quamme GA. Molecular identification of ancient and modern mammalian magnesium transporters. Am J Physiol, Cell Physiol. 2010;298: C407-429. doi:10.1152/ajpcell.00124.2009

108. Stuiver M, Lainez S, Will C, Terryn S, Günzel D, Debaix H, et al. CNNM2, encoding a basolateral protein required for renal $\mathrm{Mg} 2+$ handling, is mutated in dominant hypomagnesemia. Am J Hum Genet. 2011;88: 333-343. doi:10.1016/j.ajhg.2011.02.005

109. Yamazaki D, Funato Y, Miura J, Sato S, Toyosawa S, Furutani K, et al. Basolateral Mg2+ extrusion via CNNM4 mediates transcellular Mg2+ transport across epithelia: a mouse model. PLoS Genet. 2013;9: e1003983. doi:10.1371/journal.pgen.1003983

110. Funato Y, Furutani K, Kurachi Y, Miki H. CrossTalk proposal: CNNM proteins are $\mathrm{Na}+/ \mathrm{Mg} 2+$ exchangers playing a central role in transepithelial Mg2+ (re)absorption. J Physiol. 2018;596: 743746. doi:10.1113/JP275248

111. Arjona FJ, de Baaij JHF. CrossTalk opposing view: CNNM proteins are not $\mathrm{Na}+/ \mathrm{Mg} 2+$ exchangers but Mg2+ transport regulators playing a central role in transepithelial Mg2+ (re)absorption. J Physiol (Lond). 2018;596: 747-750. doi:10.1113/JP275249

112. Funato Y, Furutani K, Kurachi Y, Miki H. Rebuttal from Yosuke Funato, Kazuharu Furutani, Yoshihisa Kurachi and Hiroaki Miki. J Physiol. 2018;596: 751. doi:10.1113/JP275706

113. Arjona FJ, de Baaij JHF. Rebuttal from Francisco J. Arjona and Jeroen H. F. de Baaij. J Physiol. 2018;596: 753-754. doi:10.1113/JP275705 
114. Sponder G, Mastrototaro L, Kurth K, Merolle L, Zhang Z, Abdulhanan N, et al. Human CNNM2 is not a $\mathrm{Mg}(2+)$ transporter per se. Pflugers Arch. 2016;468: 1223-1240. doi:10.1007/s00424-0161816-7

115. Huang $Y$, Jin F, Funato $Y, X u Z$, Zhu W, Wang J, et al. Structural basis for the Mg2+ recognition and regulation of the CorC Mg2+ transporter. Sci Adv. 2021;7: eabe6140.

doi:10.1126/sciadv.abe6140

116. Hogue DL, Ellison MJ, Young JD, Cass CE. Identification of a novel membrane transporter associated with intracellular membranes by phenotypic complementation in the yeast Saccharomyces cerevisiae. J Biol Chem. 1996;271: 9801-9808. doi:10.1074/jbc.271.16.9801 117. Cabrita MA, Hobman TC, Hogue DL, King KM, Cass CE. Mouse transporter protein, a membrane protein that regulates cellular multidrug resistance, is localized to lysosomes. Cancer Res. 1999;59: 4890-4897.

118. Hogue DL, Kerby L, Ling V. A mammalian lysosomal membrane protein confers multidrug resistance upon expression in Saccharomyces cerevisiae. J Biol Chem. 1999;274: 12877-12882. doi:10.1074/jbc.274.18.12877

119. Tian S, Muneeruddin K, Choi MY, Tao L, Bhuiyan RH, Ohmi Y, et al. Genome-wide CRISPR screens for Shiga toxins and ricin reveal Golgi proteins critical for glycosylation. PLoS Biol. 2018;16: e2006951. doi:10.1371/journal.pbio.2006951

120. Yamaji T, Sekizuka T, Tachida Y, Sakuma C, Morimoto K, Kuroda M, et al. A CRISPR Screen Identifies LAPTM4A and TM9SF Proteins as Glycolipid-Regulating Factors. iScience. 2019;11: 409424. doi:10.1016/j.isci.2018.12.039

121. Shao G-Z, Zhou R-L, Zhang Q-Y, Zhang Y, Liu J-J, Rui J-A, et al. Molecular cloning and characterization of LAPTM4B, a novel gene upregulated in hepatocellular carcinoma. Oncogene. 2003;22: 5060-5069. doi:10.1038/sj.onc.1206832

122. Adra CN, Zhu S, Ko JL, Guillemot JC, Cuervo AM, Kobayashi H, et al. LAPTM5: a novel lysosomal-associated multispanning membrane protein preferentially expressed in hematopoietic cells. Genomics. 1996;35: 328-337. doi:10.1006/geno.1996.0364

123. Grabner A, Brast S, Sucic S, Bierer S, Hirsch B, Pavenstädt $H$, et al. LAPTM4A interacts with hOCT2 and regulates its endocytotic recruitment. Cell Mol Life Sci. 2011;68: 4079-4090. doi:10.1007/s00018-011-0694-6

124. Milkereit R, Persaud A, Vanoaica L, Guetg A, Verrey F, Rotin D. LAPTM4b recruits the LAT14F2hc Leu transporter to lysosomes and promotes mTORC1 activation. Nat Commun. 2015;6: 7250. doi:10.1038/ncomms8250

125. Li L, Wei XH, Pan YP, Li HC, Yang H, He QH, et al. LAPTM4B: a novel cancer-associated gene motivates multidrug resistance through efflux and activating PI3K/AKT signaling. Oncogene. 2010;29: 5785-5795. doi:10.1038/onc.2010.303

126. Rutsch F, Gailus S, Miousse IR, Suormala T, Sagné C, Toliat MR, et al. Identification of a putative lysosomal cobalamin exporter altered in the cblF defect of vitamin B12 metabolism. Nat Genet. 2009;41: 234-239. doi:10.1038/ng.294

127. Kawaguchi K, Okamoto T, Morita M, Imanaka T. Translocation of the ABC transporter ABCD4 from the endoplasmic reticulum to lysosomes requires the escort protein LMBD1. Sci Rep. 2016;6: 30183. doi:10.1038/srep30183

128. Kitai K, Kawaguchi K, Tomohiro T, Morita M, So T, Imanaka T. The lysosomal protein ABCD4 can transport vitamin B12 across liposomal membranes in vitro. J Biol Chem. 2021;296: 100654. doi:10.1016/j.jbc.2021.100654

129. Wojnar P, Lechner M, Merschak P, Redl B. Molecular cloning of a novel lipocalin-1 interacting human cell membrane receptor using phage display. J Biol Chem. 2001;276: 2020620212. doi:10.1074/jbc.M101762200

130. Hesselink RW, Findlay JBC. Expression, characterization and ligand specificity of lipocalin-1 interacting membrane receptor (LIMR). Mol Membr Biol. 2013;30: 327-337.

doi:10.3109/09687688.2013.823018 
bioRxiv preprint doi: https://doi.org/10.1101/2021.11.19.469292; this version posted November 20, 2021. The copyright holder for this preprint (which was not certified by peer review) is the author/funder, who has granted bioRxiv a license to display the preprint in perpetuity. It is made available under aCC-BY 4.0 International license.

131. Paek J, Kalocsay M, Staus DP, Wingler L, Pascolutti R, Paulo JA, et al. Multidimensional Tracking of GPCR Signaling via Peroxidase-Catalyzed Proximity Labeling. Cell. 2017;169: 338-349.e11. doi:10.1016/j.cell.2017.03.028

132. Lettice LA, Heaney SJH, Purdie LA, Li L, de Beer P, Oostra BA, et al. A long-range Shh enhancer regulates expression in the developing limb and fin and is associated with preaxial polydactyly. Hum Mol Genet. 2003;12: 1725-1735. doi:10.1093/hmg/ddg180

133. lanakiev P, van Baren MJ null, Daly MJ, Toledo SP, Cavalcanti MG, Neto JC, et al.

Acheiropodia is caused by a genomic deletion in C7orf2, the human orthologue of the Lmbr1 gene.

Am J Hum Genet. 2001;68: 38-45. doi:10.1086/316955

134. MacGrogan D, Levy A, Bova GS, Isaacs WB, Bookstein R. Structure and methylationassociated silencing of a gene within a homozygously deleted region of human chromosome band 8p22. Genomics. 1996;35: 55-65. doi:10.1006/geno.1996.0322

135. Knauer R, Lehle L. The oligosaccharyltransferase complex from Saccharomyces cerevisiae. Isolation of the OST6 gene, its synthetic interaction with OST3, and analysis of the native complex. J Biol Chem. 1999;274: 17249-17256. doi:10.1074/jbc.274.24.17249

136. Knauer R, Lehle $L$. The oligosaccharyltransferase complex from yeast. Biochim Biophys Acta. 1999;1426: 259-273. doi:10.1016/s0304-4165(98)00128-7

137. Kelleher DJ, Karaoglu D, Mandon EC, Gilmore R. Oligosaccharyltransferase isoforms that contain different catalytic STT3 subunits have distinct enzymatic properties. Mol Cell. 2003;12: 101111. doi:10.1016/s1097-2765(03)00243-0

138. Cherepanova NA, Shrimal S, Gilmore R. Oxidoreductase activity is necessary for Nglycosylation of cysteine-proximal acceptor sites in glycoproteins. J Cell Biol. 2014;206: 525-539. doi:10.1083/jcb.201404083

139. Ramírez AS, Kowal J, Locher KP. Cryo-electron microscopy structures of human oligosaccharyltransferase complexes OST-A and OST-B. Science. 2019;366: 1372-1375. doi:10.1126/science.aaz3505

140. Goytain A, Quamme GA. Identification and characterization of a novel mammalian Mg2+ transporter with channel-like properties. BMC Genomics. 2005;6: 48. doi:10.1186/1471-2164-6-48 141. Zhou H, Clapham DE. Mammalian MagT1 and TUSC3 are required for cellular magnesium uptake and vertebrate embryonic development. Proc Natl Acad Sci USA. 2009;106: 15750-15755. doi:10.1073/pnas.0908332106

142. Li N, Gügel IL, Giavalisco P, Zeisler V, Schreiber L, Soll J, et al. FAX1, a novel membrane protein mediating plastid fatty acid export. PLoS Biol. 2015;13: e1002053.

doi:10.1371/journal.pbio.1002053

143. Nilsson R, Schultz IJ, Pierce EL, Soltis KA, Naranuntarat A, Ward DM, et al. Discovery of genes essential for heme biosynthesis through large-scale gene expression analysis. Cell Metab. 2009;10: 119-130. doi:10.1016/j.cmet.2009.06.012

144. Yien YY, Robledo RF, Schultz IJ, Takahashi-Makise N, Gwynn B, Bauer DE, et al. TMEM14C is required for erythroid mitochondrial heme metabolism. J Clin Invest. 2014;124: 4294-4304. doi:10.1172/JCl76979

145. Yien YY, Ringel AR, Paw BH. Mitochondrial transport of protoporphyrinogen IX in erythroid cells. Oncotarget. 2015;6: 20742-20743. doi:10.18632/oncotarget.5124

146. Klammt C, Maslennikov I, Bayrhuber M, Eichmann C, Vajpai N, Chiu EJC, et al. Facile backbone structure determination of human membrane proteins by NMR spectroscopy. Nat Methods. 2012;9: 834-839. doi:10.1038/nmeth.2033

147. Almagro Armenteros JJ, Salvatore M, Emanuelsson O, Winther O, von Heijne G, Elofsson A, et al. Detecting sequence signals in targeting peptides using deep learning. Life Sci Alliance. 2019;2. doi:10.26508/Isa.201900429

148. Shen D-W, Ma J, Okabe M, Zhang G, Xia D, Gottesman MM. Elevated expression of TMEM205, a hypothetical membrane protein, is associated with cisplatin resistance. J Cell Physiol. 2010;225: 822-828. doi:10.1002/jcp.22287 
149. Gallenito MJ, Qasim TS, Tutol JN, Prakash V, Dodani SC, Meloni G. A recombinant platform to characterize the role of transmembrane protein hTMEM205 in Pt(II)-drug resistance and extrusion. Metallomics. 2020;12: 1542-1554. doi:10.1039/d0mt00114g

150. Tusnády GE, Simon I. The HMMTOP transmembrane topology prediction server. Bioinformatics. 2001;17: 849-850. doi:10.1093/bioinformatics/17.9.849

151. Chang J-M, Di Tommaso P, Taly J-F, Notredame C. Accurate multiple sequence alignment of transmembrane proteins with PSI-Coffee. BMC Bioinformatics. 2012;13 Suppl 4: S1. doi:10.1186/1471-2105-13-S4-S1

152. Camacho C, Coulouris G, Avagyan V, Ma N, Papadopoulos J, Bealer K, et al. BLAST+: architecture and applications. BMC Bioinformatics. 2009;10: 421. doi:10.1186/1471-2105-10-421 153. Steinegger M, Meier M, Mirdita M, Vöhringer H, Haunsberger SJ, Söding J. HH-suite3 for fast remote homology detection and deep protein annotation. BMC Bioinformatics. 2019;20: 473. doi:10.1186/s12859-019-3019-7

154. Remmert M, Biegert A, Hauser A, Söding J. HHblits: lightning-fast iterative protein sequence searching by HMM-HMM alignment. Nat Methods. 2011;9: 173-175. doi:10.1038/nmeth.1818

155. Mirdita M, von den Driesch L, Galiez C, Martin MJ, Söding J, Steinegger M. Uniclust databases of clustered and deeply annotated protein sequences and alignments. Nucleic Acids Res. 2017;45: D170-D176. doi:10.1093/nar/gkw1081

156. Sievers F, Wilm A, Dineen D, Gibson TJ, Karplus K, Li W, et al. Fast, scalable generation of high-quality protein multiple sequence alignments using Clustal Omega. Mol Syst Biol. 2011;7: 539. doi:10.1038/msb.2011.75

157. Sievers F, Higgins DG. Clustal Omega for making accurate alignments of many protein sequences. Protein Sci. 2018;27: 135-145. doi:10.1002/pro.3290

158. Lefort V, Longueville J-E, Gascuel O. SMS: Smart Model Selection in PhyML. Mol Biol Evol. 2017;34: 2422-2424. doi:10.1093/molbev/msx149

159. Guindon S, Dufayard J-F, Lefort V, Anisimova M, Hordijk W, Gascuel O. New algorithms and methods to estimate maximum-likelihood phylogenies: assessing the performance of PhyML 3.0. Syst Biol. 2010;59: 307-321. doi:10.1093/sysbio/syq010

160. Anisimova M, Gascuel O. Approximate likelihood-ratio test for branches: A fast, accurate, and powerful alternative. Syst Biol. 2006;55: 539-552. doi:10.1080/10635150600755453

161. Chen K, Durand D, Farach-Colton M. NOTUNG: a program for dating gene duplications and optimizing gene family trees. J Comput Biol. 2000;7: 429-447. doi:10.1089/106652700750050871 
bioRxiv preprint doi: https://doi org/10.1101/2021.11.19.469292; this version posted November 20,2021 . The copyright holder for this preprint (which was not certified by peer review) is the author/funder, who has granted bioRxiv a license to display the preprint in perpetuity. It is made available under aCC-BY 4.0 International license.

\section{Figures and Tables}

\section{Table 1}

Families and subfamilies examined from the TCDB for SLC-like proteins. Superfamilies marked by arrows have been analyzed. The superfamily \#1.A was examined since several existing SLC families are classified here, while superfamily \#2.A was expected to contain most known SLC proteins.

Superfamilies \#9.A and \#9.B were also examined. Numbers show the total number of level 3 families and level 4 subfamilies in each superfamily.

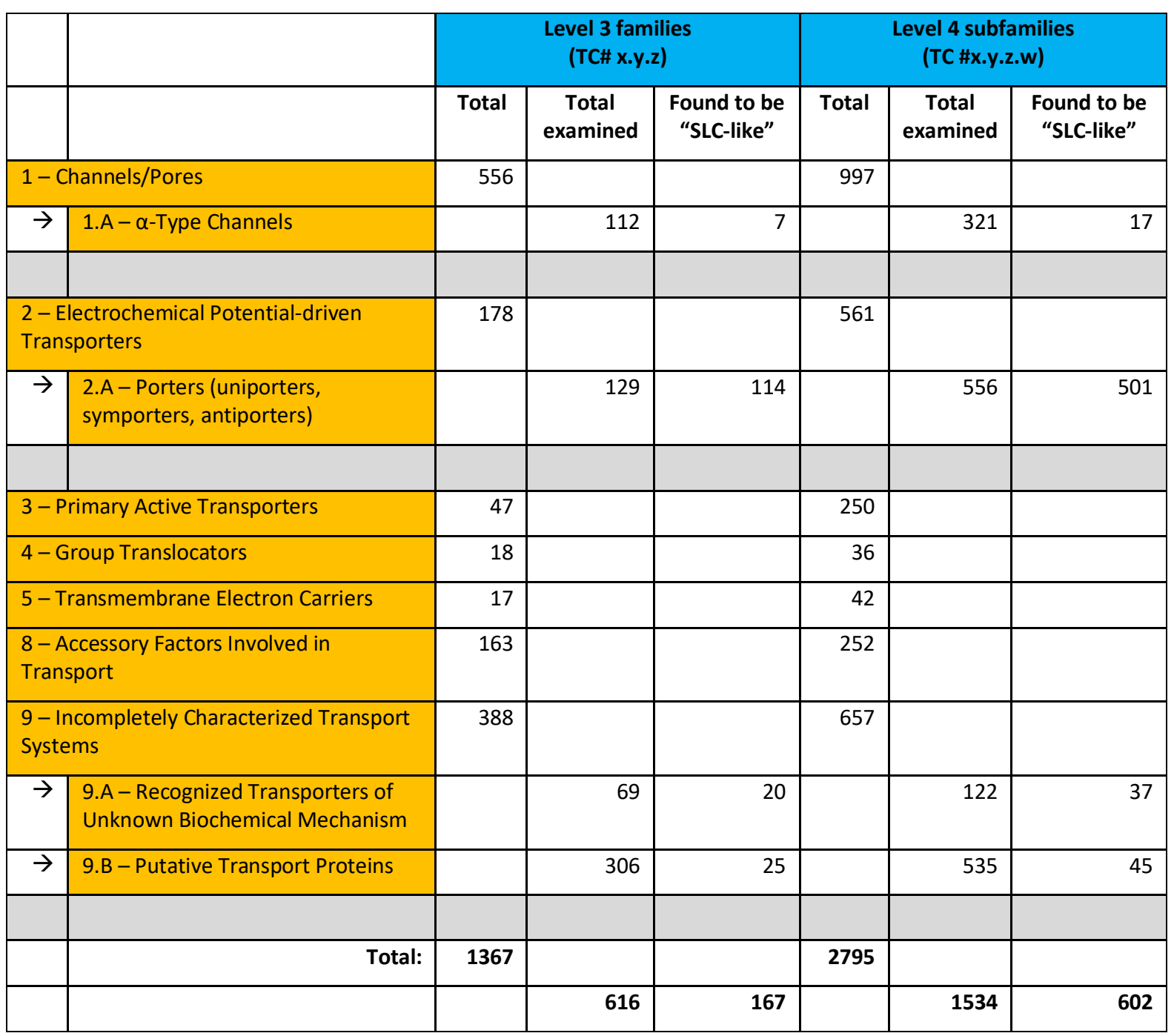




\section{Table 2}

Results of the initial search for "SLC-like" proteins. The search was performed using HMM-based sequence similarity analysis based on selected families and subfamilies from the TCDB, as well as selected Pfam models that likely encode transmembrane domains of "SLC-like" transporters (see text for details). The table shows the number of families, subfamilies from the TCDB and the number of Pfam models that had representative sequences in each organism. In addition, the initial number of found "SLC-like" proteins is shown.

\begin{tabular}{|l|r|r|r|r|}
\hline Found: & \multicolumn{1}{|c|}{$\begin{array}{c}\text { Level 3 families } \\
\text { (TC \#x.y.z) }\end{array}$} & $\begin{array}{c}\text { Level 4 subfamilies } \\
\text { (TC \#x.y.z.w) }\end{array}$ & Pfam models & Proteins \\
\hline Human (H. sapiens) & 67 & 310 & 82 & 532 \\
\hline Mouse (M. musculus) & 68 & 316 & 81 & 540 \\
\hline Rat (R. norvegicus) & 68 & 318 & 82 & 676 \\
\hline Zebrafish (D. rerio) & 66 & 314 & 68 & 475 \\
\hline Chicken (G. gallus) & 61 & 307 & 71 & 435 \\
\hline $\begin{array}{l}\text { Fruitfly (D. } \\
\text { melanogaster) }\end{array}$ & 60 & 276 & & 537 \\
\hline $\begin{array}{l}\text { Roundworm (C. } \\
\text { elegans) }\end{array}$ & & 285 & & 71 \\
\hline
\end{tabular}




\section{Table 3}

Novel SLC-like proteins. The table shows SLC-like human proteins from our search that are not in the "classical" group of SLCs (SLC1-52 families). The most similar (highest-scoring) TCDB family/subfamily and Pfam family are shown, as well as the most similar (highest-scoring) protein with structural information based on the pdb70 dataset. Substrate information, where available, was retrieved from available literature. Based on our search, SLC families SLC53-66 have recently been incorporated into the nomenclature in collaboration with the HUGO/HGNC.

\begin{tabular}{|c|c|c|c|c|c|c|c|c|c|}
\hline Family name & UniProt ID & Gene symbol & I TCDB family & y Pfam family & Protein name & Closest PDB & Structural fold & Substrates & Remarks \\
\hline SLC18 & Q8NHS3 & MFSD8 & 2.A.1.2 & MFS_1 & $\begin{array}{l}\text { Major facilitator superfamily domain-containing } \\
\text { protein } 8\end{array}$ & $7 \mathrm{mjs} x$ & MFS & orphan & $\begin{array}{l}\text { lysosomal } \\
\text { [PMID:17564970], related } \\
\text { to CLN7 (ceroid } \\
\text { lipofuscinosis type 7) } \\
\text { [PMID:17564970,PMID:191 } \\
\text { 77532], might be related to } \\
\text { mTOR signaling } \\
\text { [PMID:29514215] } \\
\end{array}$ \\
\hline SLC18 & Q8NBP5 & MFSD9 & 2.A.1.2 & MFS_1 & $\begin{array}{l}\text { Major facilitator superfamily domain-containing } \\
\text { protein } 9\end{array}$ & 4zw9A & MFS & orphan & \\
\hline SLC18 & Q14728 & MFSD10 & 2.A.1.2 & MFS_1 & $\begin{array}{l}\text { Major facilitator superfamily domain-containing } \\
\text { protein } 10\end{array}$ & $6 s 4 \mathrm{~mA}$ & MFS & $\begin{array}{l}\text { indomethacin } \\
\text { [PubChem:3715,PMID:18638446] }\end{array}$ & \\
\hline SLC18 & Q96MC6 & MFSD14A & 2.A.1.2 & MFS_1 & Hippocampus abundant transcript 1 protein & $7 \mathrm{mjs}$ & MFS & orphan & $\begin{array}{l}\text { affected by nutrient } \\
\text { availability } \\
\text { [PMID:28179877], loss } \\
\text { causes globozoospermia in } \\
\text { mice [PMID:27107036] }\end{array}$ \\
\hline SLC18 & Q5SR56 & MFSD14B & 2.A.1.2 & MFS_1 & Hippocampus abundant transcript-like protein 1 & $7 \mathrm{mjs}$ & MFS & orphan & \begin{tabular}{|l|} 
affected by nutrient \\
availability \\
[PMID:28179877] \\
\end{tabular} \\
\hline SLC18 & Q5VZR4 & MFSD14C & 2.A.1.2 & MFS_1 & Hippocampus abundant transcript-like protein 2 & $6 \mathrm{kklA}$ & MFS & orphan & \\
\hline SLC18 & Q96Bl1 & SLC22A18 & 2.A.1.2 & MFS_1 & Solute carrier family 22 member 18 & 6e9cA & MFS & orphan & $\begin{array}{l}\text { also has an antisense gene } \\
\text { (SLC22A18AS) }\end{array}$ \\
\hline SLC22 & Q7L0J3 & $\begin{array}{l}\text { SV2A } \\
\text { (SLC22B1) }\end{array}$ & 2.A.1.22 & Sugar_tr & Synaptic vesicle glycoprotein $2 \mathrm{~A}$ & $4 \mathrm{j} 05 \mathrm{~A}$ & MFS & $\begin{array}{l}\text { galactose [PubChem:6036,PMID:25326386]; } \\
\text { also binds levetiracetam } \\
\text { [PubChem:5284583,PMID:15210974], } \\
\text { seletracetam } \\
\text { [PubChem:9942725,PMID:18183537], } \\
\text { brivaracetam } \\
\text { [PubChem:9837243,PMID:14736235,PMID:17 } \\
\text { 785672]. }\end{array}$ & \\
\hline SLC22 & Q7L1/2 & $\begin{array}{l}\text { SV2B } \\
\text { (SLC22B2) }\end{array}$ & 2.A.1.22 & MFS_1 & Synaptic vesicle glycoprotein 2B & $4 j 05 \mathrm{~A}$ & MFS & orphan & \\
\hline SLC22 & Q496J9 & $\begin{array}{l}\text { SV2C } \\
\text { (SLC22B3) }\end{array}$ & 2.A.1.22 & MFS_1 & Synaptic vesicle glycoprotein $2 \mathrm{C}$ & $4 \mathrm{j} 05 \mathrm{~A}$ & MFS & orphan & $\begin{array}{l}\text { neuronal receptor of } \\
\text { botulinum toxin A } \\
{[\text { [PMID:31783045] }}\end{array}$ \\
\hline SLC22 & Q8N4V2 & $\begin{array}{l}\text { SVOP } \\
\text { (SLC22B4) }\end{array}$ & 2.A.1.82 & Sugar_tr & Synaptic vesicle 2 -related protein & $4 z w 9 A$ & MFS & $\begin{array}{l}\text { nicotinate [PubChem:937,PMID:21953179]; } \\
\text { binds nucleotides in the TM region: 8-azido- } \\
\text { ATP [PubChem:2735431,PMID:19390693]; ATP } \\
\text { [PubChem:5957,PMID:19390693]; GTP } \\
\text { [PubChem:135398633,PMID:19390693]; TTP } \\
\text { [PubChem:64968,PMID:19390693]; CTP }\end{array}$ & \\
\hline
\end{tabular}




\begin{tabular}{|c|c|c|c|c|c|c|c|c|c|}
\hline & & & & & & & & $\begin{array}{l}\text { [PubChem:6176,PMID:19390693]; NAD } \\
\text { [PubChem:5892,PMID:19390693] }\end{array}$ & \\
\hline SLC22 & Q8N434 & $\begin{array}{l}\text { SVOPL } \\
\text { (SLC22B5) }\end{array}$ & 2.A.1.82 & MFS_1 & Putative transporter SVOPL & $4 j 05 \mathrm{~A}$ & MFS & orphan & \\
\hline SLC33 & Q96ES6 & MFSD3 & 2.A.1.57 & Acatn & $\begin{array}{l}\text { Major facilitator superfamily domain-containing } \\
\text { protein } 3\end{array}$ & $7 \mathrm{~d} 19 \mathrm{~A}$ & MFS & orphan & \\
\hline SLC35 & Q24JQ0 & TMEM241 & 2.A.7.13 & TPT & Transmembrane protein 241 & 50 ogeD & NST & orphan & \\
\hline SLC51 & Q6ZMB5 & TMEM184A & 2.A.82 & Solute_trans_a & Transmembrane protein 184A & & & orphan & $\begin{array}{l}\text { receptor for heparin } \\
\text { [PMID:26769966] }\end{array}$ \\
\hline SLC51 & Q9Y519 & TMEM184B & 2.A.82 & Solute_trans_a & Transmembrane protein 184B & & & orphan & $\begin{array}{l}\text { might modulate the } \\
\text { transport of ibuprofen } \\
\text { [PMID:31066233] }\end{array}$ \\
\hline SLC51 & Q9NVA4 & TMEM184C & 2.A.82 & Solute_trans_a & Transmembrane protein $184 \mathrm{C}$ & & & orphan & \\
\hline SLC53 & Q9UBH6 & \begin{tabular}{|l} 
XPR1 \\
(SLC53A1)
\end{tabular} & 2.A.94 & EXS & Xenotropic and polytropic retrovirus receptor 1 & & & phosphate [PubChem:1061,PMID:23791524] & \\
\hline SLC54 & Q9Y5U8 & $\begin{array}{l}\text { MPC1 } \\
\text { (SLC54A1) }\end{array}$ & 2.A.105 & MPC & Mitochondrial pyruvate carrier 1 & & & $\begin{array}{l}\text { pyruvate } \\
\text { [PubChem:107735,PMID:22628554,PMID:226 } \\
28558]\end{array}$ & \\
\hline SLC54 & 095563 & $\begin{array}{l}\text { MPC2 } \\
\text { (SLC54A2) }\end{array}$ & 2.A.105 & MPC & Mitochondrial pyruvate carrier 2 & & & pyruvate [PubChem:107735,PMID:22628558] & \\
\hline SLC54 & PODKB6 & $\begin{array}{l}\text { MPC1L } \\
\text { (SLC54A3) }\end{array}$ & 2.A.105 & MPC & Mitochondrial pyruvate carrier 1-like protein & & & pyruvate [PubChem:107735,PMID:27317664] & \\
\hline SLC55 & 095202 & $\begin{array}{l}\text { LETM1 } \\
\text { (SLC55A1) }\end{array}$ & 2.A.97 & LETM1 & Mitochondrial proton/calcium exchanger protein & & & $\begin{array}{l}\text { K+/H+ } \\
\text { [PubChem:813,PubChem:1038,PMID:1513825 } \\
\text { 3,PMID:17925330,PMID:17541427,PMID:2019 } \\
\text { 7279] }\end{array}$ & $\begin{array}{l}\text { Ca2+/H+ transport function } \\
\text { [PMID:19797662,PMID:276 } \\
\text { 69901] is debated } \\
\text { [PMID:24616706]. }\end{array}$ \\
\hline SLC55 & Q2VYF4 & $\begin{array}{l}\text { LETM2 } \\
\text { (SLC55A2) }\end{array}$ & 2.A.97 & LETM1 & $\begin{array}{l}\text { LETM1 domain-containing protein LETM2, } \\
\text { mitochondrial }\end{array}$ & & & orphan & \\
\hline SLC55 & Q6P1Q0 & $\begin{array}{l}\text { LETMD1 } \\
\text { (SLC55A3) }\end{array}$ & 2.A.97 & LETM1 & LETM1 domain-containing protein 1 & & & orphan & \\
\hline SLC56 & Q9H9B4 & $\begin{array}{l}\text { SFXN1 } \\
\text { (SLC56A1) }\end{array}$ & 2.A.54 & Mtc & Sideroflexin-1 & & & L-serine [PubChem:5951,PMID:30442778] & \\
\hline SLC56 & Q96NB2 & $\begin{array}{l}\text { SFXN2 } \\
\text { (SLC56A2) }\end{array}$ & 2.A.54 & Mtc & Sideroflexin-2 & & & orphan & \\
\hline SLC56 & Q9BWM7 & $\begin{array}{l}\text { SFXN3 } \\
\text { (SLC56A3) }\end{array}$ & 2.A.54 & Mtc & Sideroflexin-3 & & & orphan & $\begin{array}{l}\text { expressed in the } \\
\text { mitochondria of neurons } \\
\text { [PMID:31177362] }\end{array}$ \\
\hline SLC56 & Q6P4A7 & $\begin{array}{l}\text { SFXN4 } \\
\text { (SLC56A4) }\end{array}$ & 2.A.54 & Mtc & Sideroflexin-4 & & & orphan & $\begin{array}{l}\text { knockout affects Fe-S } \\
\text { biogenesis } \\
\text { [PMID:31873120], and } \\
\text { mutations can be causative } \\
\text { of macrocytic anemia } \\
\text { [PMID:24119684] }\end{array}$ \\
\hline SLC56 & Q8TD22 & $\begin{array}{l}\text { SFXN5 } \\
\text { (SLC56A5) }\end{array}$ & 2.A.54 & Mtc & Sideroflexin-5 & & & orphan & \\
\hline SLC57 & Q7RTP0 & $\begin{array}{l}\text { NIPA1 } \\
\text { (SLC57A1) }\end{array}$ & 2.A.7.25 & Mg_trans_NIPA & Magnesium transporter NIPA1 & $5 i 20 D$ & NST & $\begin{array}{l}\text { Mg2+ } \\
\text { [PubChem:888,PMID:17166836,PMID:186676 } \\
\text { 02]; to a lesser extent Sr2+ } \\
\text { [PubChem:104798,PMID:17166836,PMID:186 } \\
\text { 67602],Fe2+ } \\
\text { [PubChem:27284,PMID:17166836,PMID:1866 }\end{array}$ & \\
\hline
\end{tabular}




\begin{tabular}{|c|c|c|c|c|c|c|c|c|c|}
\hline & & & & & & & & $\begin{array}{l}\text { 7602],Co2+ } \\
\text { [PubChem:104729,PMID:17166836,PMID:186 } \\
\text { 67602] }\end{array}$ & \\
\hline SLC57 & Q8N8Q9 & $\begin{array}{l}\text { NIPA2 } \\
\text { (SLC57A2) }\end{array}$ & 2.A.7.25 & Mg_trans_NIPA & Magnesium transporter NIPA2 & 6ukjA & NST & $\begin{array}{l}\text { very specific to Mg2+ } \\
\text { [PubChem:888,PMID:18667602] }\end{array}$ & \\
\hline SLC57 & Q6NVV3 & $\begin{array}{l}\text { NIPAL1 } \\
\text { (SLC57A3) }\end{array}$ & 2.A.7.25 & Mg_trans_NIPA & Magnesium transporter NIPA3 & 6ukjA & NST & $\begin{array}{l}\text { Mg2+ [PubChem:888,PMID:18667602]; Sr2+ } \\
\text { [PubChem:104798,PMID:18667602]; Ba2+ } \\
\text { [PubChem:104810,PMID:18667602]; Fe2+ } \\
\text { [PubChem:27284,PMID:18667602]; Cu2+ } \\
\text { [PubChem:27099,PMID:18667602] }\end{array}$ & \\
\hline SLC57 & Q9H841 & $\begin{array}{l}\text { NIPAL2 } \\
\text { (SLC57A4) }\end{array}$ & 2.A.7.25 & Mg_trans_NIPA & NIPA-like protein 2 & 6ukjA & NST & $\begin{array}{l}\text { Mg2+ [PubChem:888,PMID:18667602]; Sr2+ } \\
\text { [PubChem:104798,PMID:18667602]; Ba2+ } \\
\text { [PubChem:104810,PMID:18667602] }\end{array}$ & $\begin{array}{l}\text { NIPA4 referenced in } \\
\text { [PMID:18667602] points to } \\
\text { GenBank entry NM_024759, } \\
\text { which corresponds to } \\
\text { NIPAL2/SLC57A4, in } \\
\text { contrast to the } \\
\text { nomenclature in UniProt. }\end{array}$ \\
\hline SLC57 & Q6P499 & $\begin{array}{l}\text { NIPAL3 } \\
\text { (SLC57A5) }\end{array}$ & 2.A.7.25 & Mg_trans_NIPA & NIPA-like protein 3 & 6ukjA & NST & orphan & \begin{tabular}{|l|} 
knockout mice have a \\
pleiotropic phenotype \\
[PMID:19738379]
\end{tabular} \\
\hline SLC57 & QOD2KO & $\begin{array}{l}\text { NIPAL4 } \\
\text { (SLC57A6) }\end{array}$ & 2.A.7.25 & Mg_trans_NIPA & Magnesium transporter NIPA4 & 6ukjA & NST & orphan & $\begin{array}{l}\text { associated with autosomal } \\
\text { recessive congenital } \\
\text { ichthyosis [PMID:20301593] }\end{array}$ \\
\hline SLC58 & Q9HOU3 & $\begin{array}{l}\text { MAGT1 } \\
\text { (SLC58A1) }\end{array}$ & 1.A.76.1 & OST3_OST6 & Magnesium transporter protein 1 & $6 \mathrm{~s} 7 \mathrm{tH}$ & MagT & Mg2+ [PubChem:888,PMID:15804357] & $\begin{array}{l}\text { Might have a channel-like } \\
\text { mechanism } \\
\text { [PMID:19940067]. }\end{array}$ \\
\hline SLC58 & Q13454 & $\begin{array}{l}\text { TUSC3 } \\
\text { (SLC58A2) }\end{array}$ & 1.A.76.1 & OST3_OST6 & Tumor suppressor candidate 3 & $6 \mathrm{~s} 7 \mathrm{tH}$ & MagT & $\begin{array}{l}\text { Mg2+ } \\
\text { [PubChem:888,PMID:18667602,PMID:199400 } \\
\text { 67], Fe2+ } \\
\text { [PubChem:27284,PMID:18667602,PMID:1994 } \\
\text { 0067], Cu2+ } \\
\text { [PubChem:27099,PMID:18667602,PMID:1994 } \\
\text { 0067], Mn2+ } \\
\text { [PubChem:27854,PMID:19940067] }\end{array}$ & \\
\hline SLC59 & Q8NA29 & $\begin{array}{l}\text { MFSD2A } \\
\text { (SLC59A1) }\end{array}$ & 2.A.2.3 & MFS_2 & $\begin{array}{l}\text { Sodium-dependent lysophos phatidylcholine } \\
\text { symporter } 1\end{array}$ & $7 \mathrm{mjs} X$ & MFS & $\begin{array}{l}\text { LPC DHA (docosahexaenoic acid) } \\
\text { [PubChem:10415542,PMID:24828044]; LPC } \\
\text { palmitate [PubChem:460602,PMID:24828044]; } \\
\text { TopFluor LPE [CAS:2260795-55- } \\
\text { 7,PMID:24828044] }\end{array}$ & \\
\hline SLC59 & A6NFX1 & \begin{tabular}{|l} 
MFSD2B \\
(SLC59A2)
\end{tabular} & 2.A.2.3 & MFS_2 & $\begin{array}{l}\text { Major facilitator superfamily domain-containing } \\
\text { protein } 2 \mathrm{~B}\end{array}$ & $7 \mathrm{mjs}$ & MFS & $\begin{array}{l}\text { sphingosine-1-phosphate (S1P) } \\
\text { [PubChem:5283560,PMID:29563527,PMID:29 } \\
\text { 045386,PMID:33785361] }\end{array}$ & \\
\hline SLC59 & Q6NUT3 & MFSD12 & 2.A.2.7 & MFS_2 & $\begin{array}{l}\text { Major facilitator superfamily domain-containing } \\
\text { protein } 12\end{array}$ & $7 \mathrm{mjs} X$ & MFS & cysteine [PubChem:5862,PMID:33208952] & $\begin{array}{l}\text { plays a role in skin } \\
\text { pigmentation } \\
\text { [PMID:29025994] }\end{array}$ \\
\hline SLC59 & Q14CX5 & MFSD13A & 2.A.2.3 & MFS_2 & Transmembrane protein 180 & $7 \mathrm{mjs}$ & MFS & orphan & \\
\hline SLC60 & Q8N468 & $\begin{array}{l}\text { MFSD4A } \\
\text { (SLC60A1) }\end{array}$ & 2.A.1.7 & MFS_1 & $\begin{array}{l}\text { Major facilitator superfamily domain-containing } \\
\text { protein 4A }\end{array}$ & $4 \mathrm{j05A}$ & MFS & orphan & \\
\hline SLC60 & Q5TF39 & $\begin{array}{l}\text { MFSD4B } \\
\text { (SLC60A2) }\end{array}$ & 2.A.1.7 & MFS_1 & Sodium-dependent glucose transporter 1 & $7 c k o A$ & MFS & $\begin{array}{l}\text { alpha-methyl-d-glucopyranoside } \\
\text { [PubChem:64947,PMID:12590146]; D-glucose } \\
\text { [PubChem:5793,PMID:12590146]; urea } \\
\text { [PubChem:1176,PMID:26423860] }\end{array}$ & \\
\hline
\end{tabular}




\begin{tabular}{|c|c|c|c|c|c|c|c|c|c|}
\hline SLC61 & Q6N075 & $\begin{array}{l}\text { MFSD5 } \\
\text { (SLC61A1) }\end{array}$ & 2.A.1.40 & MFS_5 & Molybdate-anion transporter & $6 v b g A$ & MFS & molybdate [PubChem:24621,PMID:21464289] & \\
\hline SLC62 & Q9HCJ1 & $\begin{array}{l}\text { ANKH } \\
\text { (SLC62A1) }\end{array}$ & 2.A.66.9 & ANKH & Progressive ankylosis protein homolog & $4 z 3 p A$ & MATE & $\begin{array}{l}\text { pyrophosphate } \\
\text { [PubChem:644102,PMID:10894769] }\end{array}$ & \\
\hline SLC63 & Q9H2V7 & $\begin{array}{l}\text { SPNS1 } \\
\text { (SLC63A1) }\end{array}$ & 2.A.1.49 & MFS_1 & Protein spinster homolog 1 & $6 \mathrm{v} 4 \mathrm{dA}$ & MFS & orphan & \\
\hline SLC63 & Q8IVW8 & $\begin{array}{l}\text { SPNS2 } \\
\text { (SLC63A2) }\end{array}$ & 2.A.1.49 & MFS_1 & Protein spinster homolog 2 & $7 \mathrm{mjsX}$ & MFS & $\begin{array}{l}\text { sphingosine-1-phosphate (S1P) } \\
\text { [PubChem:5283560,PMID:19074308,PMID:21 } \\
\text { 084291]; phosphorylated Fingolimod (FTY720- } \\
\text { P) [PubChem:9908268,PMID:21084291]; } \\
\text { dihydrosphingosine-1-phosphate (DH-S1P) } \\
\text { [PubChem:644260,PMID:21084291]; phyto- } \\
\text { S1P [PubChem:10883829,PMID:21084291]; } \\
\text { C17-S1P [PubChem:5283559,PMID:21084291] }\end{array}$ & \\
\hline SLC63 & Q6ZMD2 & $\begin{array}{l}\text { SPNS3 } \\
\text { (SLC63A3) }\end{array}$ & 2.A.1.49 & MFS_1 & Protein spinster homolog 3 & $7 m j s X$ & MFS & orphan & \\
\hline SLC64 & Q9HC07 & $\begin{array}{l}\text { TMEM165 } \\
\text { (SLC64A1) }\end{array}$ & 2.A.106.2 & UPF0016 & Transmembrane protein 165 & & & $\begin{array}{l}\text { Ca2+/H+ } \\
\text { [PubChem:271,PubChem:1038,PMID:2356928 } \\
\text { 3,PMID:27008884]; Mn2+ } \\
\text { [PubChem:27854,PMID:27008884,PMID:2827 } \\
\text { 0545] }\end{array}$ & \\
\hline SLC65 & 015118 & $\begin{array}{l}\text { NPC1 } \\
\text { (SLC65A1) }\end{array}$ & 2.A.6.6 & Patched & NPC intracellular cholesterol transporter 1 & $6 w 5 r A$ & RND & $\begin{array}{l}\text { cholesterol } \\
\text { [PubChem:5997,PMID:17989073,PMID:17989 } \\
\text { 072,PMID:27410046] }\end{array}$ & \\
\hline SLC65 & Q9UHC9 & $\begin{array}{l}\text { NPC1L1 } \\
\text { (SLC65A2) }\end{array}$ & 2.A.6.6 & Patched & NPC1-like intracellular cholesterol transporter 1 & $6 \mathrm{v} 3 \mathrm{hA}$ & RND & cholesterol [PubChem:5997,PMID:14976318] & \\
\hline SLC65 & Q13635 & PTCH1 & 2.A.6.6 & Patched & Protein patched homolog 1 & $6 \mathrm{n} 7 \mathrm{kD}$ & RND & cholesterol [PubChem:5997,PMID:33199907] & $\begin{array}{l}\text { might be a multi-drug } \\
\text { transporter } \\
\text { [PMID:30110910] }\end{array}$ \\
\hline SLC65 & Q9Y6C5 & PTCH2 & 2.A.6.6 & Patched & Protein patched homolog 2 & $6 \mathrm{n} 7 \mathrm{kD}$ & RND & $\begin{array}{l}\text { likely cholesterol } \\
\text { [PubChem:5997,PMID:33199907] based on } \\
\text { functional similarity to PTCH1 }\end{array}$ & \\
\hline SLC65 & Q96NR3 & PTCHD1 & 2.A.6.6 & Patched & Patched domain-containing protein 1 & $7 \mathrm{dzpA}$ & RND & orphan & \begin{tabular}{|l} 
associated with autism \\
spectrum disorder and \\
intellectual disability \\
[PMID:20844286], might be \\
related to the transport of a \\
metabolite in the \\
kynurenine pathway \\
[PMID:31515500] \\
\end{tabular} \\
\hline SLC65 & Q3KNS1 & PTCHD3 & 2.A.6.6 & Patched & Patched domain-containing protein 3 & $6 w 5 r A$ & RND & orphan & \\
\hline SLC65 & Q6zW05 & PTCHD4 & 2.A.6.6 & Patched & Patched domain-containing protein 4 & $6 \mathrm{w} 5 \mathrm{rA}$ & RND & orphan & \\
\hline SLC65 & Q12770 & SCAP & 2.A.6.6 & Sterol-sensing & $\begin{array}{l}\text { Sterol regulatory element-binding protein } \\
\text { cleavage-activating protein }\end{array}$ & 7 etwB & SCAP_full & $\begin{array}{l}\text { cholesterol [PubChem:5997,PMID:33446483], } \\
\text { 25-hydroxycholesterol } \\
\text { [PubChem:65094,PMID:33446483] }\end{array}$ & \\
\hline SLC66 & Q6ZP29 & $\begin{array}{l}\text { PQLC2 } \\
\text { (SLC66A1) }\end{array}$ & 2.A.43.2 & PQ-loop & Lysosomal amino acid transporter 1 homolog & $5 x p d A$ & SWEET & $\begin{array}{l}\text { L-Arg [PubChem:6322,PMID:22822152]; L-Lys } \\
\text { [PubChem:5962,PMID:22822152]; L-His } \\
\text { [PubChem:6274,PMID:22822152]; L- } \\
\text { canavanine } \\
\text { [PubChem:439202,PMID:23169667]; L- } \\
\text { ornithine [PubChem:6262,PMID:23169667]; }\end{array}$ & \\
\hline
\end{tabular}




\begin{tabular}{|c|c|c|c|c|c|c|c|c|c|}
\hline & & & & & & & & $\begin{array}{l}\text { cysteamine-cysteine mixed disulfide } \\
\text { [PubChem:424083,PMID:23169667] }\end{array}$ & \\
\hline SLC66 & Q8N2U9 & $\begin{array}{l}\text { PQLC1 } \\
\text { (SLC66A2) }\end{array}$ & 2.A.43 & PQ-loop & PQ-loop repeat-containing protein 1 & $5 x p d A$ & SWEET & orphan & \\
\hline SLC66 & Q8N755 & $\begin{array}{l}\text { PQLC3 } \\
\text { (SLC66A3) }\end{array}$ & 2.A.43.3 & PQ-loop & PQ-loop repeat-containing protein 3 & $5 x p d A$ & SWEET & orphan & \\
\hline SLC66 & 060931 & $\begin{array}{l}\text { CTNS } \\
\text { (SLC66A4) }\end{array}$ & 2.A.43.1 & PQ-loop & Cystinosin & $5 x p d A$ & SWEET & $\begin{array}{l}\text { L-cystine [PubChem:67678,PMID:11689434]; } \\
\text { L-selenocystine [PubChem:207306]; L- } \\
\text { cystathionine [PubChem:439258]; H+ } \\
\text { [PubChem:1038,PMID:11689434,PMID:22232 } \\
\text { 659] }\end{array}$ & \\
\hline SLC66 & 075352 & $\begin{array}{l}\text { MPDU1 } \\
\text { (SLC66A5) }\end{array}$ & 2.A.43.3 & PQ-loop & Mannose-P-dolichol utilization defect 1 protein & $5 x p d A$ & SWEET & orphan & $\begin{array}{l}\text { linked to congenital } \\
\text { disorder of glycosylation } \\
\text { [PMID:29721919,PMID:117 } \\
\text { 33564] }\end{array}$ \\
\hline SLC66 & A1A4F0 & PQLC2L & 2.A.43.2 & PQ-loop & Putative uncharacterized protein PQLC2L & $5 x p d A$ & SWEET & orphan & \\
\hline pSLC.ARV1 & $\mathrm{Q} 9 \mathrm{H} 2 \mathrm{C} 2$ & ARV1 & 9.A.19 & Arv1 & Protein ARV1 & & & orphan & $\begin{array}{l}\text { might play a role in } \\
\text { membrane sterol } \\
\text { homeostasis } \\
\text { [PMID:23668914] or the } \\
\text { flipping of a GPI } \\
\text { intermediate } \\
{[\text { PMMID:32449190], also }} \\
\text { linked to epileptic } \\
\text { encephalopathy } \\
\text { [PMID:32462292] }\end{array}$ \\
\hline pSLC.Battenin & Q13286 & CLN3 & 2.A.57.5 & CLN3 & Battenin & $60 b 7 A$ & MFS & orphan & $\begin{array}{l}\text { linked to Batten/CLN3 } \\
\text { disease [PMID:34274435] }\end{array}$ \\
\hline pSLC.CLCN & P35523 & CLCN1 & 2.A.49.2 & Voltage_CLC & Chloride channel protein 1 & $6 \operatorname{coy} A$ & CLC & $\begin{array}{l}\text { channel for chloride } \\
\text { [PubChem:312,PMID:9565403]; thiocyanate } \\
\text { [PubChem:9322,PMID:9565403]; perchlorate } \\
\text { [PubChem:123351,PMID:9565403]; bromide } \\
\text { [PubChem:259,PMID:9565403]; nitrate } \\
\text { [PubChem:943,PMID:9565403]; chlorate } \\
\text { [PubChem:104770,PMID:9565403]; iodide } \\
\text { [PubChem:30165,PMID:9565403] }\end{array}$ & $\begin{array}{l}\text { linked to myotonia } \\
\text { [PMID:29845874] }\end{array}$ \\
\hline pSLC.CLCN & P51788 & CLCN2 & 2.A.49.2 & Voltage_CLC & Chloride channel protein 2 & 6 coyA & CLC & $\begin{array}{l}\text { channel for chloride } \\
\text { [PubChem:312,PMID:1311421]; bromide } \\
\text { [PubChem:259,PMID:1311421]; iodide } \\
\text { [PubChem:30165,PMID:1311421] }\end{array}$ & $\begin{array}{l}\text { associated with a variety of } \\
\text { diseases [PMID:28534947] }\end{array}$ \\
\hline pSLC.CLCN & P51790 & CLCN3 & 2.A.49.2 & Voltage_CLC & $\mathrm{H}(+) / \mathrm{Cl}(-)$ exchange transporter 3 & $7 \mathrm{Cq5D}$ & CLC & $\begin{array}{l}\text { antiport of chloride } \\
\text { [PubChem:312,PMID:29917234]; and H+ } \\
\text { [PubChem:1038,PMID:29917234] }\end{array}$ & $\begin{array}{l}\text { present in endosomal } \\
\text { compartments and synaptic } \\
\text { vesicles [PMID:11182090], } \\
\text { also in synaptic-like } \\
\text { microvesicles (SLMV) } \\
\text { [PMID:15073168] }\end{array}$ \\
\hline pSLC.CLCN & P51793 & CLCN4 & 2.A.49.2 & Voltage_CLC & $\mathrm{H}(+) / \mathrm{Cl}(-)$ exchange transporter 4 & $7 \mathrm{Cq5D}$ & CLC & $\begin{array}{l}\text { antiport of chloride } \\
\text { [PubChem:312,PMID:16034421,PMID:160344 } \\
\text { 22]; and H+ } \\
\text { [PubChem:1038,PMID:16034421,PMID:16034 } \\
\text { 422]; also nitrate } \\
\text { [PubChem:943,PMID:9873029]; bromide }\end{array}$ & \\
\hline
\end{tabular}




\begin{tabular}{|c|c|c|c|c|c|c|c|c|c|}
\hline & & & & & & & & $\begin{array}{l}\text { [PubChem:259,PMID:9873029]; iodide } \\
\text { [PubChem:30165,PMID:9873029] }\end{array}$ & \\
\hline pSLC.CLCN & P51795 & CLCN5 & 2.A.49.2 & Voltage_CLC & $\mathrm{H}(+) / \mathrm{Cl}(-)$ exchange transporter 5 & $7 \mathrm{Cq5D}$ & CLC & $\begin{array}{l}\text { antiport of chloride } \\
\text { [PubChem:312,PMID:16034421,PMID:160344 } \\
\text { 22]; and H+ } \\
\text { [PubChem:1038,PMID:16034421,PMID:16034 } \\
\text { 422]; also nitrate } \\
\text { [PubChem:943,PMID:9873029]; bromide } \\
\text { [PubChem:259,PMID:9873029]; iodide } \\
\text { [PubChem:30165,PMID:9873029] }\end{array}$ & $\begin{array}{l}\text { linked to Dent's disease } \\
\text { [PMID:7874126,PMID:8575 } \\
\text { 751,PMID:8559248] }\end{array}$ \\
\hline pSLC.CLCN & P51797 & CLCN6 & 2.A.49.3 & Voltage_CLC & Chloride transport protein 6 & $7 \mathrm{Cq5D}$ & CLC & $\begin{array}{l}\text { antiport of chloride } \\
\text { [PubChem:312,PMID:20466723]; and } \mathrm{H}+ \\
\text { [PubChem:1038,PMID:20466723]; also nitrate } \\
\text { [PubChem:943,PMID:20466723]; iodide } \\
\text { [PubChem:30165,PMID:20466723] }\end{array}$ & $\begin{array}{l}\text { expressed in late } \\
\text { endosomes of the neurons } \\
\text { [PMID:16950870] }\end{array}$ \\
\hline pSLC.CLCN & P51798 & CLCN7 & 2.A.49.3 & Voltage_CLC & $\mathrm{H}(+) / \mathrm{Cl}(-)$ exchange transporter 7 & 7cq5D & CLC & $\begin{array}{l}\text { antiport of chloride } \\
\text { [PubChem:312,PMID:18449189]; and H+ } \\
\text { [PubChem:1038,PMID:18449189] }\end{array}$ & $\begin{array}{l}\text { expressed in lysosomes } \\
\text { [PMID:18449189], } \\
\text { associated with } \\
\text { osteopetrosis } \\
\text { [PMID:11207362], obligate } \\
\text { partner of Ostm1 } \\
\text { [PMID:16525474] }\end{array}$ \\
\hline pSLC.CLCN & P51800 & CLCNKA & 2.A.49.2 & Voltage_CLC & Chloride channel protein CIC-Ka & 6qvuA & CLC & $\begin{array}{l}\text { channel for chloride } \\
\text { [PubChem:312,PMID:11734858]; bromide } \\
\text { [PubChem:259,PMID:11734858]; nitrate } \\
\text { [PubChem: 943,PMID:11734858]; iodide } \\
\text { [PubChem:30165,PMID:11734858] }\end{array}$ & $\begin{array}{l}\text { expressed in the kidney } \\
\text { [PMID:8041726] and } \\
\text { cochlea [PMID:11734858], } \\
\text { interacts with the beta- } \\
\text { subunit barttin } \\
\text { [PMID:9326936] }\end{array}$ \\
\hline pSLC.CLCN & P51801 & CLCNKB & 2.A.49.2 & Voltage_CLC & Chloride channel protein CIC-Kb & 6qvuA & CLC & $\begin{array}{l}\text { channel for chloride } \\
\text { [PubChem:312,PMID:11734858]; bromide } \\
\text { [PubChem:259,PMID:11734858]; nitrate } \\
\text { [PubChem: 943,PMID:11734858]; iodide } \\
\text { [PubChem:30165,PMID:11734858] }\end{array}$ & $\begin{array}{l}\text { expressed in the kidney } \\
\text { [PMID:8041726] and } \\
\text { cochlea [PMID:11734858], } \\
\text { associated with Bartter's } \\
\text { syndrome [PMID:9326936], } \\
\text { interacts with the beta- } \\
\text { subunit barttin } \\
\text { [PMID:9326936] }\end{array}$ \\
\hline pSLC.CNNM & Q9NRU3 & CNNM1 & 1.A.112 & DUF21 & Metal transporter CNNM1 & $7 \mathrm{~m} 1 \mathrm{tA}$ & CorC_large & orphan & $\begin{array}{l}\text { expressed in brain and testis } \\
\text { [PMID:22399287] }\end{array}$ \\
\hline pSLC.CNNM & Q9H8M5 & CNNM2 & 1.A.112 & DUF21 & Metal transporter CNNM2 & $7 \mathrm{~m} 1 \mathrm{tA}$ & CorC_large & $\begin{array}{l}\text { Mg2+ [PubChem:888,PMID:15899945]; Co2+ } \\
\text { [PubChem:104729,PMID:15899945]; Mn2+ } \\
\text { [PubChem:27854,PMID:15899945]; Sr2+ } \\
\text { [PubChem:104798,PMID:15899945]; Ba2+ } \\
\text { [PubChem:104810,PMID:15899945]; Cu2+ } \\
\text { [PubChem:27099,PMID:15899945]; Fe2+ } \\
\text { [PubChem:27284,PMID:15899945]; Na+ } \\
\text { [PubChem:923,PMID:21397062] }\end{array}$ & $\begin{array}{l}\text { expressed in kidney, lung, } \\
\text { spleen, testis } \\
\text { [PMID:22399287]; linked to } \\
\text { dominant hypomagnesemia } \\
\text { [PMID:21397062]; Mg2+ } \\
\text { transport activity has been } \\
\text { debated } \\
\text { [PMID:27068403,PMID:293 } \\
\text { 83729] }\end{array}$ \\
\hline pSLC.CNNM & Q8NE01 & CNNM3 & 1.A.112 & DUF21 & Metal transporter CNNM3 & $7 \mathrm{~m} 1 \mathrm{tA}$ & CorC_large & orphan & $\begin{array}{l}\text { expressed in kidney, brain, } \\
\text { lung, spleen, heart } \\
\text { [PMID:22399287] }\end{array}$ \\
\hline
\end{tabular}




\begin{tabular}{|c|c|c|c|c|c|c|c|c|c|}
\hline pSLC.CNNM & Q6P4Q7 & CNNM4 & 1.A.112 & DUF21 & Metal transporter CNNM4 & $7 \mathrm{~m} 1 \mathrm{tA}$ & CorC_large & $\begin{array}{l}\text { Mg2+? [PubChem:888,PMID:24339795]; } \\
\text { maybe antiport of Na+ } \\
\text { [PubChem:923,PMID:24339795] }\end{array}$ & $\begin{array}{l}\text { expressed in the basolateral } \\
\text { membrane of intestinal } \\
\text { epithelia [PMID:24339795]; } \\
\text { linked to Jalili syndrome } \\
\text { [PMID:19200525,PMID:192 } \\
\text { 00527] }\end{array}$ \\
\hline pSLC.CitMHS & Q04671 & OCA2 & 2.A.45.2 & CitMHS & P protein & 7jskA & AbgT & $\begin{array}{l}\text { maybe chloride } \\
\text { [PubChem:312,PMID:25513726] }\end{array}$ & $\begin{array}{l}\text { related to melanosome } \\
\text { function and albinism } \\
\text { [PMID:7761348,PMID:7991 } \\
\text { 586] }\end{array}$ \\
\hline pSLC.Dispatched & Q96F81 & DISP1 & 2.A.6.9 & Patched & Protein dispatched homolog 1 & $6 \mathrm{td} 6 \mathrm{~A}$ & RND & $\begin{array}{l}\text { hedgehog protein } \\
\text { [PMID:10619433,PMID:12372301] }\end{array}$ & $\begin{array}{l}\text { related to hedgehog } \\
\text { signaling }\end{array}$ \\
\hline pSLC.Dispatched & A7MBM2 & DISP2 & 2.A.6.9 & Sterol-sensing & Protein dispatched homolog 2 & $6 \times \mathrm{xe} 6 \mathrm{~A}$ & RND & orphan & \\
\hline pSLC.Dispatched & Q9P2K9 & DISP3 & 2.A.6 & Patched & Protein dispatched homolog 3 & 6td6A & RND & cholesterol? [PubChem:5997,PMID:19179482] & $\begin{array}{l}\text { expressed in neural cell } \\
\text { types [PMID:28134287, } \\
\text { might be related to thyroid } \\
\text { hormone levels } \\
\text { [PMID:19179482] }\end{array}$ \\
\hline pSLC.GPR155 & Q7Z3F1 & GPR155 & 2.A.69.3 & Mem_trans & Integral membrane protein GPR155 & $6 \operatorname{lgv} A$ & NhaA & orphan & $\begin{array}{l}\text { homologous to the } \\
\text { Drosophila anchor protein } \\
\text { [PMID:29735293] }\end{array}$ \\
\hline pSLC.LAPTM & B4EOC1 & & 2.A.74.1 & Mtp & $\begin{array}{l}\text { cDNA FLJ61683, moderately similar to Lysosomal- } \\
\text { associated multitransmembrane protein }\end{array}$ & & & orphan & \\
\hline pSLC.LAPTM & Q15012 & LAPTM4A & 2.A.74.1 & Mtp & Lysosomal-associated transmembrane protein $4 \mathrm{~A}$ & $6 w v g A$ & Tspn & $\begin{array}{l}\text { thymidine [PubChem:5789,PMID:8621662]; } \\
\text { uridine [PubChem:6029,PMID:8621662]; } \\
\text { multi-drug resistance [PMID:10212276] }\end{array}$ & $\begin{array}{l}\text { localized to late } \\
\text { endosomes/lysosomes } \\
\text { [PMID:10519401] }\end{array}$ \\
\hline pSLC.LAPTM & Q86VI4 & LAPTM4B & 2.A.74.1 & Mtp & Lysosomal-associated transmembrane protein 4B & & & $\begin{array}{l}\text { maybe ceramide } \\
\text { [PubChem:5702612,PMID:26280656]; multi- } \\
\text { drug resistance [PMID:20711237] }\end{array}$ & \\
\hline pSLC.LAPTM & Q13571 & LAPTM5 & 2.A.74.1 & Mtp & Lysosomal-associated transmembrane protein 5 & $6 w v g A$ & Tspn & orphan & $\begin{array}{l}\text { localized to lysosomes } \\
\text { [PMID:8661146] }\end{array}$ \\
\hline pSLC.LMBR-A & Q9NUN5 & LMBRD1 & 9.A.54.1 & LMBR1 & Probable lysosomal cobalamin transporter & & & orphan & $\begin{array}{l}\text { related to B12 vitamin } \\
\text { transport [PMID:27456980] }\end{array}$ \\
\hline pSLC.LMBR-B & Q8WVP7 & LMBR1 & & LMBR1 & Limb region 1 protein homolog & & & orphan & $\begin{array}{l}\text { associated with preaxial } \\
\text { polydactyly } \\
\text { [PMID:10945466,PMID:116 } \\
\text { 06546] }\end{array}$ \\
\hline pSLC.LMBR-B & Q6UX01 & LMBR1L & 9.A.54.1 & LMBR1 & Protein LMBR1L & & & orphan & $\begin{array}{l}\text { lipocalin-1 receptor } \\
\text { [PMID:23964685] }\end{array}$ \\
\hline pSLC.LMBR-B & Q68DH5 & LMBRD2 & 9.A.54.3 & LMBR1 & LMBR1 domain-containing protein 2 & & & orphan & $\begin{array}{l}\text { may play a role in beta-2-AR } \\
\text { and AT1R receptor } \\
\text { internalization } \\
\text { [PMID:28388415] }\end{array}$ \\
\hline pSLC.MFSD1 & Q9H3U5 & MFSD1 & 2.A.1.53 & MFS_1 & $\begin{array}{l}\text { Major facilitator superfamily domain-containing } \\
\text { protein } 1\end{array}$ & $7 \mathrm{mjs}$ & MFS & orphan & $\begin{array}{l}\text { affected by altered nutrient } \\
\text { intake [PMID:27981419], } \\
\text { physically interacts with } \\
\text { GLMP } \\
\text { [PMID:31661432,PMID:329 } \\
\text { 59924] }\end{array}$ \\
\hline pSLC.MFSD6 & Q6ZSS7 & MFSD6 & 2.A.1.65 & MFS_1_like & $\begin{array}{l}\text { Major facilitator superfamily domain-containing } \\
\text { protein } 6\end{array}$ & $7 \mathrm{bp} 3 \mathrm{~A}$ & MFS & sugars? & $\begin{array}{l}\text { its homolog from D. } \\
\text { melanogaster is Sugar baby, } \\
\text { which is related to life span }\end{array}$ \\
\hline
\end{tabular}




\begin{tabular}{|c|c|c|c|c|c|c|c|c|c|}
\hline & & & & & & & & & $\begin{array}{l}\text { [PMID:12620118], related } \\
\text { to energy consumption in } \\
\text { mice [PMID:31906755] }\end{array}$ \\
\hline pSLC.MFSD6 & Q8IWD5 & MFSD6L & 2.A.1.65 & MFS_1_like & $\begin{array}{l}\text { Major facilitator superfamily domain-containing } \\
\text { protein 6-like }\end{array}$ & $4 m 64 A$ & MFS & orphan & \\
\hline pSLC.OSTC & B4DH36 & & 1.A.76.2 & OST3_OST6 & cDNA FLJ52625 & $6 s 7 \mathrm{oH}$ & MagT & orphan & \\
\hline pSLC.OSTC & Q9NRP0 & OSTC & 1.A.76.2 & OST3_OST6 & Oligosaccharyltransferase complex subunit OSTC & $6 s 7 \mathrm{oH}$ & MagT & orphan & \begin{tabular}{|l} 
related to congenital \\
disorders of glycosylation \\
[PMID:32267060]
\end{tabular} \\
\hline pSLC.OSTC & Q8TBU1 & OSTCL & 1.A.76.2 & OST3_OST6 & Oligosaccharyltransferase complex subunit-like & $6 \mathrm{ftg} 3$ & OSTC_part & orphan & \\
\hline pSLC.RFT1 & Q96AA3 & RFT1 & 2.A.66.3 & Rft-1 & Protein RFT1 homolog & $6 c c 4 A$ & MATE & orphan & \begin{tabular}{|l|} 
might be a scramblase of \\
lipid-linked origosaccharides \\
[PMID:11807558], however, \\
this has been disputed \\
[PMID:33446867]
\end{tabular} \\
\hline pSLC.SIDT & Q9NXL6 & SIDT1 & 1.A.79.1 & SID-1_RNA_chan & SID1 transmembrane family member 1 & & & cholesterol [PubChem:5997,PMID:28785058] & $\begin{array}{l}\text { contradicts with originally } \\
\text { proposed function in RNA } \\
\text { uptake [PMID:21474576] }\end{array}$ \\
\hline pSLC.SIDT & Q8NBJ9 & SIDT2 & 1.A.79.1 & SID-1_RNA_chan & SID1 transmembrane family member 2 & & & cholesterol [PubChem:5997,PMID:28785058] & $\begin{array}{l}\text { contradicts with proposed } \\
\text { function in RNA uptake } \\
\text { [PMID:27046251] }\end{array}$ \\
\hline pSLC.STAR & Q14849 & STARD3 & 9.B.64 & MENTAL & StAR-related lipid transfer protein 3 & & & $\begin{array}{l}\text { probably cholesterol } \\
\text { [PubChem:5997,PMID:15976441,PMID:15718 } \\
\text { 238,PMID:12070139] }\end{array}$ & $\begin{array}{l}\text { localizes to late endosomes } \\
\text { [PMID:11053434] }\end{array}$ \\
\hline pSLC.STAR & 095772 & STARD3NL & 9.B.64 & MENTAL & STARD3 N-terminal-like protein & & & $\begin{array}{l}\text { binds cholesterol } \\
\text { [PubChem:5997,PMID:15718238] }\end{array}$ & \\
\hline pSLC.STRA & Q9BX79 & STRA6 & 2.A.90.1 & RBP_receptor & Receptor for retinol uptake STRA6 & 5sy1A & STRA6 & retinol [PubChem:445354,PMID:22815070] & \begin{tabular}{|l|} 
expressed in the basolateral \\
membrane of the retinal \\
pigment epithelium and \\
various other tissues \\
[PMID:9203140,PMID:1725 \\
5476], linked to Matthew- \\
Wood syndrome \\
[PMID:19309693]
\end{tabular} \\
\hline pSLC.TMCO3 & Q6UWJ1 & TMCO3 & 2.A.37.1 & $\mathrm{Na}$ _H_Exchanger & $\begin{array}{l}\text { Transmembrane and coiled-coil domain- } \\
\text { containing protein } 3\end{array}$ & 6z3yA & NhaA & orphan & $\begin{array}{l}\text { putative } \mathrm{Na}+/ \mathrm{H}+\text { exchanger, } \\
\text { based on similarity }\end{array}$ \\
\hline PSLC.TMEM14 & Q9Y6G1 & TMEM14A & 2.A.126.1 & Tmemb_14 & Transmembrane protein 14A & $21 \mathrm{lopA}$ & TMEM14_alt & orphan & \begin{tabular}{|l|} 
may be involved in the \\
regulation of the \\
mitochondrial membrane \\
potential [PMID:21723035]
\end{tabular} \\
\hline pSLC.TMEM14 & Q9NUH8 & TMEM14B & 2.A.126.1 & Tmemb_14 & Transmembrane protein 14B & $2 \operatorname{los} \mathrm{A}$ & TSPO & orphan & \\
\hline PSLC.TMEM14 & Q9P0S9 & TMEM14C & 2.A.126.1 & Tmemb_14 & Transmembrane protein $14 \mathrm{C}$ & $2 \operatorname{los} A$ & TSPO & $\begin{array}{l}\text { protoporphyrinogen IX } \\
\text { [PubChem:121893,PMID:25157825] }\end{array}$ & $\begin{array}{l}\text { localizes to the inner } \\
\text { mitochondrial membrane } \\
\text { [PMID:25157825], there are } \\
\text { further links to its } \\
\text { involvement in heme } \\
\text { synthesis [PMID:32968076] }\end{array}$ \\
\hline pSLC.TMEM14 & A8MWL7 & TMEM14DP & 2.A.126.1 & Tmemb_14 & Transmembrane protein 14DP & $2105 \mathrm{~A}$ & TSPO & orphan & might be a pseudogene \\
\hline pSLC.TMEM41-64 & Q96HV5 & TMEM41A & 9.B.27.1 & SNARE_assoc & Transmembrane protein 41A & & & orphan & \\
\hline pSLC.TMEM41-64 & Q5BJD5 & TMEM41B & 9.B.27.1 & SNARE_assoc & Transmembrane protein 41B & & & $\begin{array}{l}\text { scramblase of cholesterol } \\
\text { [PubChem:5997,PMID:34074213]; }\end{array}$ & \begin{tabular}{|l|} 
localized to the ER \\
[PMID:30093494], ab initio
\end{tabular} \\
\hline
\end{tabular}




\begin{tabular}{|c|c|c|c|c|c|c|c|c|c|}
\hline & & & & & & & & $\begin{array}{l}\text { phosphatidylserine } \\
\text { [PubChem:9547096,PMID:34074213] }\end{array}$ & $\begin{array}{l}\text { structure prediction shows } \\
\text { transporter-like features } \\
\text { [PMID:33520197,PMID:337 } \\
\text { 71928], required factor for } \\
\text { SARS-CoV-2 and flavivirus } \\
\text { infection } \\
\text { [PMID:33052332,PMID:333 } \\
\text { 38421] }\end{array}$ \\
\hline pSLC.TMEM41-64 & Q6YI46 & TMEM64 & 9.B.27.5 & SNARE_assoc & Transmembrane protein 64 & & & orphan & $\begin{array}{l}\text { associates with SERCA and } \\
\text { modulates its function } \\
\text { [PMID:23395171] }\end{array}$ \\
\hline pSLC.TMEM104 & Q8NE00 & TMEM104 & 2.A.18.10 & Aa_trans & Transmembrane protein 104 & $7 \mathrm{kgvB}$ & APC & orphan & $\begin{array}{l}\text { might be a housekeeping } \\
\text { gene [PMID:28386932] }\end{array}$ \\
\hline pSLC.TMEM144 & Q7Z5S9 & TMEM144 & 2.A.7.8 & TMEM144 & Transmembrane protein 144 & $5 \mathrm{i} 20 \mathrm{D}$ & NST & orphan & $\begin{array}{l}\text { linked to bovine milk } \\
\text { cholesterol content } \\
\text { [PMID:30185830] }\end{array}$ \\
\hline pSLC.TMEM163 & Q8TC26 & TMEM163 & 2.A.4.8 & Cation_efflux & Transmembrane protein 163 & 6xpeA & CDF & $\begin{array}{l}\text { Zn2+ } \\
\text { [PubChem:32051,PMID:27917477,PMID:3169 } \\
\text { 7912] }\end{array}$ & $\begin{array}{l}\text { expressed in synaptic } \\
\text { vesicles [PMID:17623043], } \\
\text { linked to Parkinson's disease } \\
\text { [PMID:25064009] }\end{array}$ \\
\hline pSLC.TMEM205 & Q6UW68 & TMEM205 & 9.A.55.1 & DUF4149 & Transmembrane protein 205 & & & orphan & $\begin{array}{l}\text { might be involved in } \\
\text { cisplatin resistance } \\
\text { [PMID:20589834,PMID:327 } \\
\text { 89331] }\end{array}$ \\
\hline pSLC.TMEM234 & Q8WY98 & TMEM234 & 2.A.7.32 & TMEM234 & Transmembrane protein 234 & 6ukjA & NST & orphan & $\begin{array}{l}\text { knockdown causes } \\
\text { proteinurea in zebrafish } \\
\text { [PMID:26377798] }\end{array}$ \\
\hline pSLC.TMEM245 & Q9H330 & TMEM245 & 2.A.86 & Al-2E_transport & Transmembrane protein 245 & & & orphan & \\
\hline pSLC.TSPO & P30536 & TSPO & 9.A.24.1 & TspO_MBR & Translocator protein & $2 \mathrm{mgyA}$ & TSPO & $\begin{array}{l}\text { protoporphyrin IX } \\
\text { [PubChem:4971,PMID:3031675,PMID:256351 } \\
\text { O1], cholesterol } \\
\text { [PubChem:5997,PMID:9925760] }\end{array}$ & $\begin{array}{l}\text { might be involved in } \\
\text { cholesterol import into } \\
\text { mitochondria } \\
\text { [PMID:9925760,PMID:1769 } \\
\text { 2008], however, diverse } \\
\text { other function have been } \\
\text { suggested [PMID:34191248] }\end{array}$ \\
\hline pSLC.TSPO & Q5TGU0 & TSPO2 & 9.A.24.1 & TspO_MBR & Translocator protein 2 & 4ryoA & TSPO & $\begin{array}{l}\text { 5-aminolevulinic acid } \\
\text { [PubChem:137,PMID:31989647] }\end{array}$ & $\begin{array}{l}\text { expressed in erythrocytes } \\
\text { [PMID:21795748] }\end{array}$ \\
\hline pSLC.UNC93 & 043934 & MFSD11 & 2.A.1.58 & UNC-93 & UNC93-like protein MFSD11 & 6vbgA & MFS & orphan & $\begin{array}{l}\text { expressed in neurons, might } \\
\text { play a role in energy } \\
\text { homeostasis } \\
\text { [PMID:27272503] }\end{array}$ \\
\hline pSLC.UNC93 & Q86WB7 & UNC93A & 2.A.1.58 & UNC-93 & Protein unc-93 homolog $\mathrm{A}$ & $7 \mathrm{c} 77 \mathrm{~B}$ & MFS & orphan & $\begin{array}{l}\text { could play an ion } \\
\text { transporter role in the } \\
\text { kidney [PMID:33163493] }\end{array}$ \\
\hline pSLC.UNC93 & Q9H1C4 & UNC93B1 & 2.A.1.58 & UNC-93 & Protein unc-93 homolog B1 & 7 cynC & MFS & orphan & $\begin{array}{l}\text { helps with the trafficking of } \\
\text { toll-like receptors to the } \\
\text { endolysosomes } \\
\text { [PMID:18305481 }\end{array}$ \\
\hline pSLC.XK & P51811 & XK & 2.A.112.1 & XK-related & Membrane transport protein XK & $7 \mathrm{p} 14 \mathrm{~A}$ & XK & orphan & $\begin{array}{l}\text { part of the Kell blood group } \\
\text { complex [PMID:16431037], } \\
\text { linked to McLeod syndrome } \\
\text { [PMID:11761473] }\end{array}$ \\
\hline
\end{tabular}




\begin{tabular}{|c|c|c|c|c|c|c|c|c|c|}
\hline pSLC.XK & Q5GH77 & XKR3 & 2.A.112.1 & XK-related & XK-related protein 3 & $7 \mathrm{p} 14 \mathrm{~A}$ & XK & orphan & $\begin{array}{l}\text { expressed in the testes } \\
\text { [PMID:16431037] }\end{array}$ \\
\hline pSLC.XK & Q5GH76 & XKR4 & 2.A.112.1 & XK-related & XK-related protein 4 & $7 \mathrm{p} 14 \mathrm{~A}$ & $\mathrm{XK}$ & $\begin{array}{l}\text { phosphatidylserine } \\
\text { [PubChem:9547096,PMID:25231987] }\end{array}$ & \begin{tabular}{|l|} 
probably a scramblase \\
[PMID:25231987] expressed \\
in the brain \\
{$[$ [PMID:25231987] }
\end{tabular} \\
\hline PSLC.XK & Q6UX68 & XKR5 & 2.A.112.1 & XK-related & XK-related protein 5 & $7 \mathrm{p} 14 \mathrm{~A}$ & $\mathrm{XK}$ & orphan & \\
\hline pSLC.XK & Q5GH73 & XKR6 & 2.A.112.1 & XK-related & XK-related protein 6 & $7 p 14 A$ & $\mathrm{XK}$ & orphan & $\begin{array}{l}\text { associated with depression } \\
\text { and neuroticism } \\
\text { [PMID:32109668,PMID:295 } \\
\text { 59929,PMID:28552732], } \\
\text { epilepsy [PMID:28533195], } \\
\text { lupus erythematosus } \\
\text { [PMID:29967481,PMID:209 } \\
\text { 47557], and serum } \\
\text { cholesterol and lipid levels } \\
\text { [PMID:32024373,PMID:201 } \\
\text { 60193] }\end{array}$ \\
\hline pSLC.XK & Q5GH72 & XKR7 & 2.A.112.1 & XK-related & XK-related protein 7 & $7 \mathrm{p} 14 \mathrm{~A}$ & $\mathrm{XK}$ & orphan & \\
\hline pSLC.XK & Q9H6D3 & XKR8 & 2.A.112.1 & XK-related & XK-related protein 8 & $7 p 14 A$ & $\mathrm{XK}$ & $\begin{array}{l}\text { phosphatidylserine } \\
\text { [PubChem:9547096,PMID:23845944] }\end{array}$ & $\begin{array}{l}\text { functions as a scramblase } \\
\text { [PMID:23845944] }\end{array}$ \\
\hline pSLC.XK & Q5GH70 & XKR9 & 2.A.112.1 & XK-related & XK-related protein 9 & $7 \mathrm{p} 14 \mathrm{~A}$ & XK & $\begin{array}{l}\text { phosphatidylserine } \\
\text { [PubChem:9547096,PMID:25231987] }\end{array}$ & $\begin{array}{l}\text { probably a scramblase } \\
{[\text { [PMID:25231987] expressed }} \\
\text { in the intestine } \\
{[\text { [PMID:25231987] }}\end{array}$ \\
\hline pSLC.XK & Q6PP77 & XKRX & 2.A.112.1 & XK-related & XK-related protein 2 & $7 \mathrm{p} 14 \mathrm{~A}$ & $\mathrm{XK}$ & orphan & $\begin{array}{l}\text { expressed mostly in } \\
\text { placenta and adrenal gland } \\
\text { [PMID:16431037] }\end{array}$ \\
\hline
\end{tabular}


bioRxiv preprint doi: https://doi org/10.1101/2021.11.19.469292 - this version posted November 20, 2021. The copyright holder for this preprint (which was not certified by peer review) is the author/funder, who has granted bioRxiv a license to display the preprint in perpetuity. It is made available under aCC-BY 4.0 International license.

Figure 1

Dendrogram of human SLC-like protein families based on HMM fingerprint-based clustering. Classical and newly incorporated SLC families are shown with colors. Since SLC proteins are polyphyletic, which manifests itself in mathematically orthogonal HMM fingerprints that cannot be further clustered, the dendrogram does not join into a single branch.

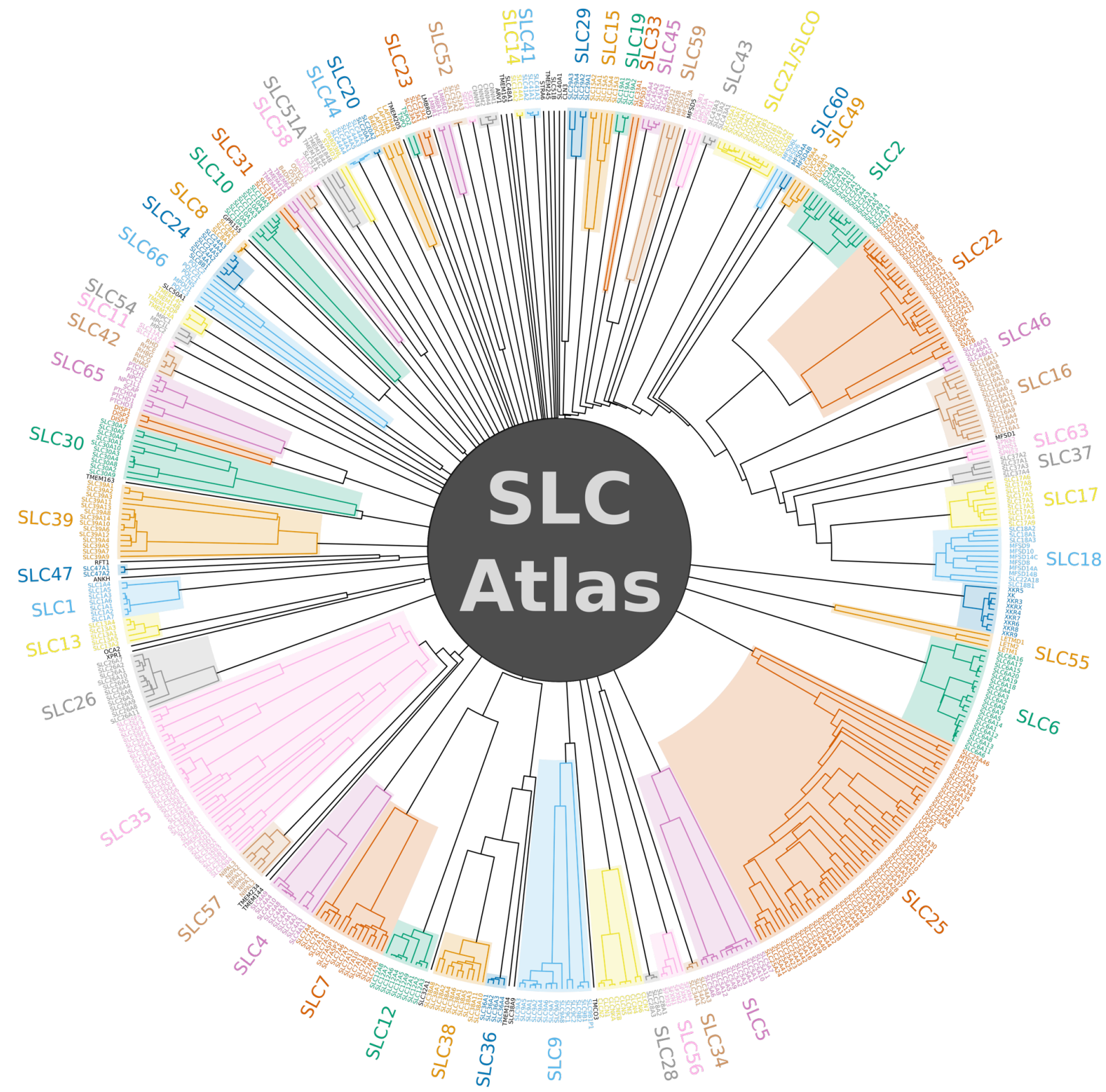


bioRxiv preprint doi: https://doi.org/10.1101/2021.11.19.469292; this version posted November 20, 2021. The copyright holder for this preprint (which was not certified by peer review) is the author/funder, who has granted bioRxiv a license to display the preprint in perpetuity. It is made available under aCC-BY 4.0 International license.

Figure 2

Orthology analysis of SLC-like proteins based on the human lineage. Each line shows a gene cluster that has evolved through gene duplication events along the human lineage. The human gene in the cluster, if present, is noted in the text label. Normal grey boxes in each column indicate a 1:1 orthology relationship between the human gene and a corresponding gene in the organism specified. Dark grey boxes indicate that the human gene has several orthologs, and light grey boxes indicate that several human genes share a common ortholog in that organism. White boxes denote no ortholog in the organism specified, while lines without a human gene name correspond to genes that have been lost in human.

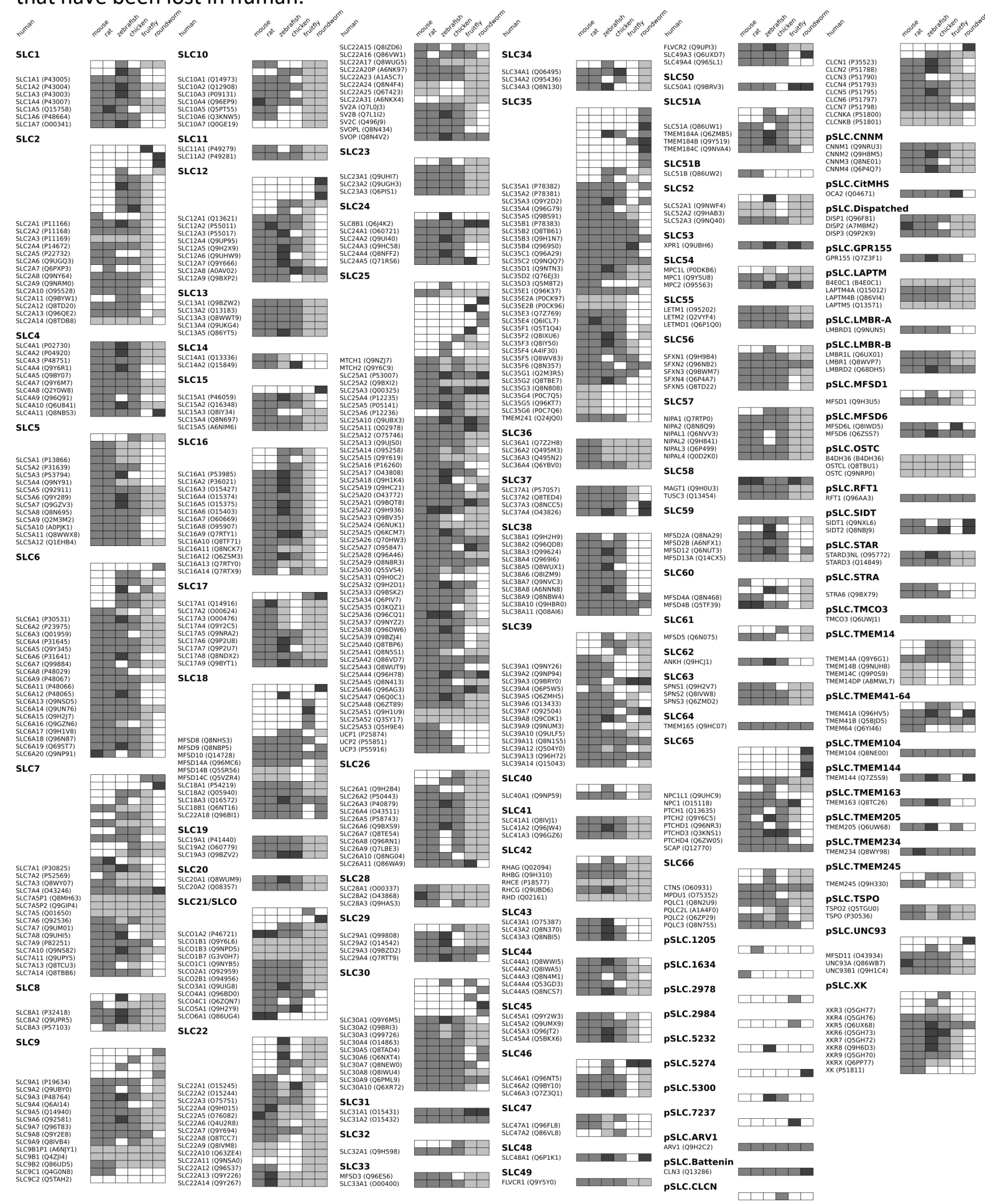


Figure 3

Phylogenetic tree of the SLC17, SLC18 and SLC37 families and proteins clustering in their neighborhood. Branch support values $\geq 0.7$ are shown.

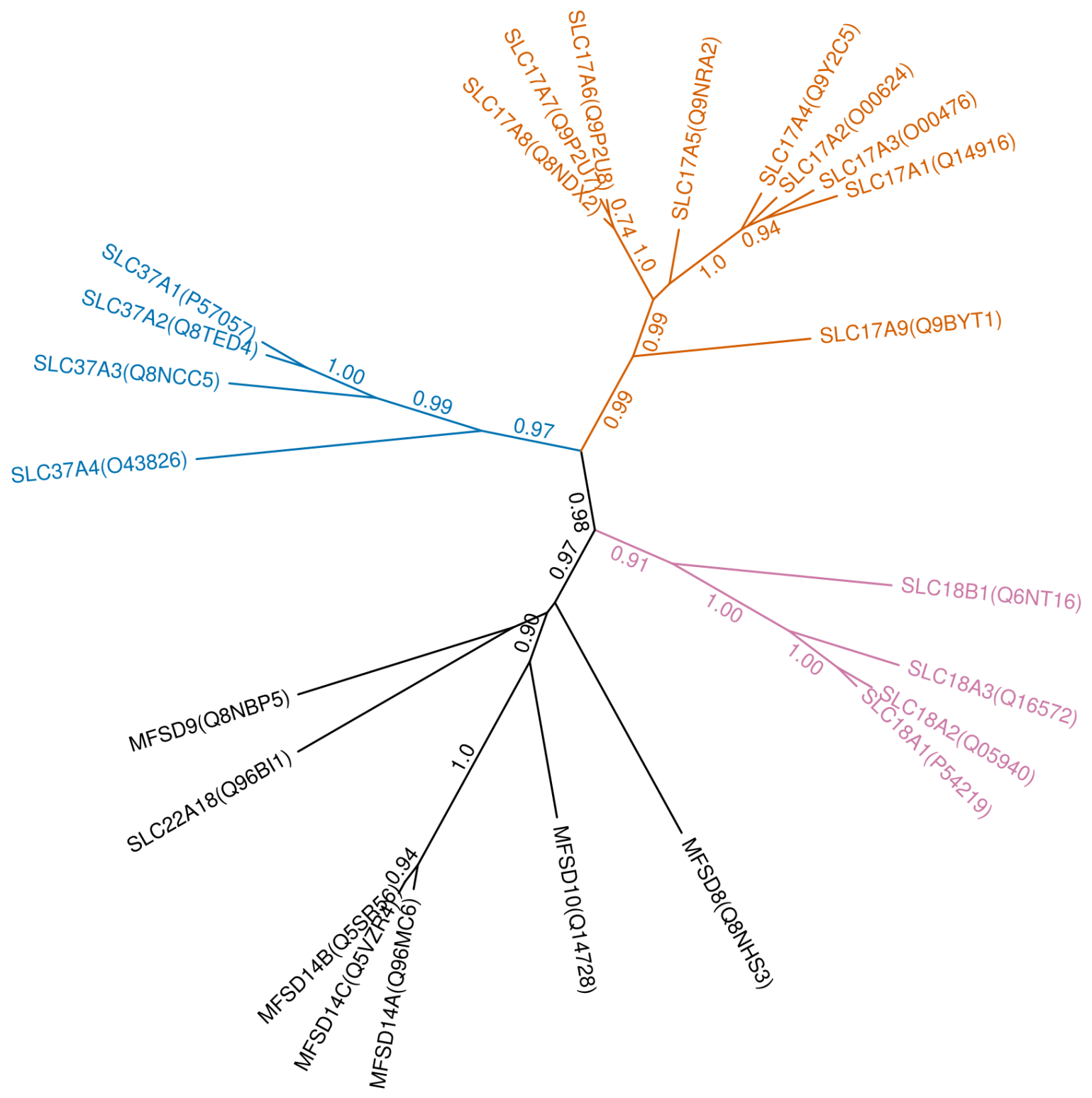


Figure 4

Phylogenetic tree of proteins clustering in the SLC38-36-32 families and TMEM104. Branch support values $\geq 0.5$ are shown. SLC32 and SLC36 family members are colored gold and blue, respectively.

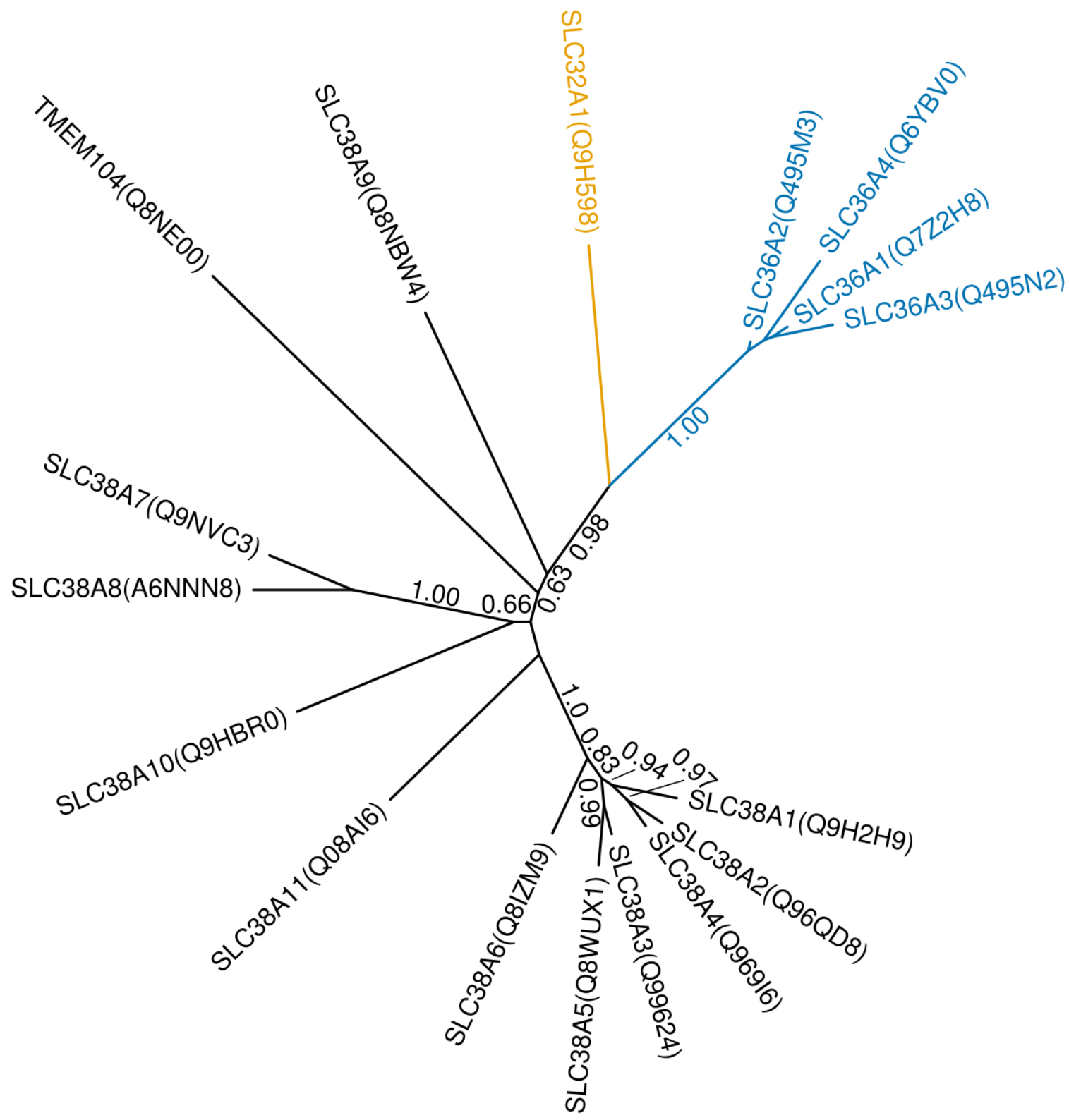


bioRxiv preprint doi: https://doi org/10.1101/2021.11.19.469292; this version posted November 20, 2021. The copyright holder for this preprint (which was not certified by peer review) is the author/funder, who has granted bioRxiv a license to display the preprint in perpetuity. It is made available under aCC-BY 4.0 International license.

Figure 5

Phylogenetic tree of proteins with HMM fingerprints overlapping with the SLC35 family. Branch support values $\geq 0.7$ are shown. The different subfamilies are colored in various colors.

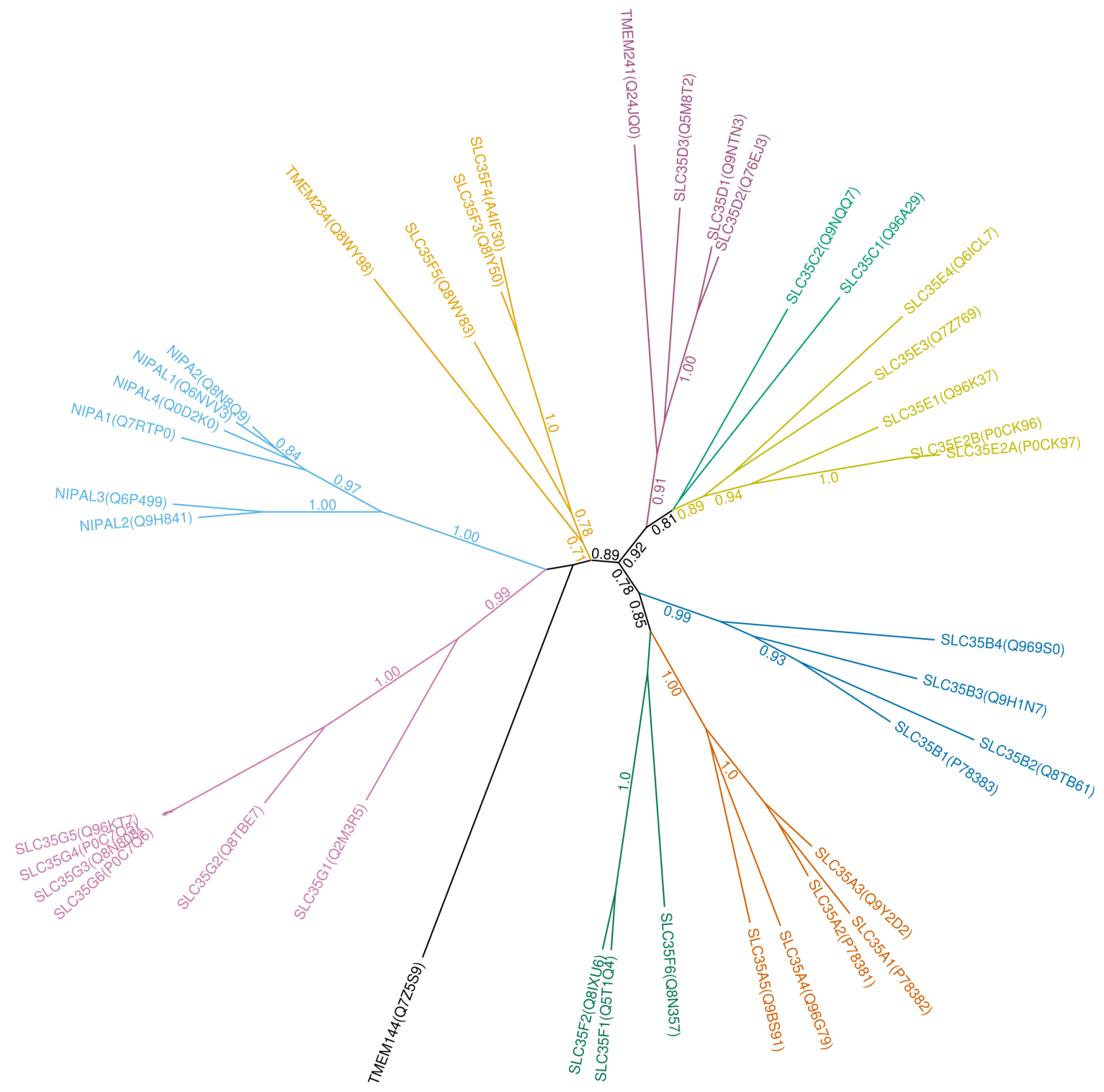


Supplementary information

Supplementary Table 1

"SLC-like" Pfam domains and their clan memberships. The dataset is a result of our manual curation based on our "SLC-like" criteria (see text) and Pfam families present in protein sequences listed in the TCDB. Family names and data are from the Pfam database.

\begin{tabular}{|c|c|c|c|c|}
\hline Family ID & Family name & Clan ID & Clan name & Family description \\
\hline PF03390 & $2 \mathrm{HCT}$ & & & 2-hydroxycarboxylate transporter family \\
\hline PF00324 & AA_permease & CL0062 & APC & Amino acid permease \\
\hline PF13520 & AA_permease_2 & CL0062 & APC & Amino acid permease \\
\hline PF01490 & Aa_trans & CL0062 & APC & Transmembrane amino acid transporter protein \\
\hline PF06541 & ABC_trans_CmpB & & & Putative ABC-transporter type IV \\
\hline PF03806 & ABG_transport & CL0182 & IT & AbgT putative transporter family \\
\hline PF13000 & Acatn & CL0015 & MFS & Acetyl-coenzyme A transporter 1 \\
\hline PF00873 & ACR_tran & CL0322 & RND_permease & AcrB/AcrD/AcrF family \\
\hline PF01594 & Al-2E_transport & & & Al-2E family transporter \\
\hline PF06610 & AlaE & & & L-alanine exporter \\
\hline PF11744 & ALMT & CL0307 & FUSC & Aluminium activated malate transporter \\
\hline PF00909 & Ammonium_transp & & & Ammonium Transporter Family \\
\hline PF07260 & ANKH & CL0222 & MviN_MATE & Progressive ankylosis protein (ANKH) \\
\hline PF06081 & ArAE_1 & CL0307 & FUSC & Aromatic acid exporter family member 1 \\
\hline PF10334 & ArAE_2 & CL0307 & FUSC & Aromatic acid exporter family member 2 \\
\hline PF02040 & ArsB & CL0182 & IT & Arsenical pump membrane protein \\
\hline PF03773 & ArsP_1 & & & Predicted permease \\
\hline PF11449 & ArsP_2 & & & Putative, 10TM heavy-metal exporter \\
\hline PF04161 & Arv1 & & & Arv1-like family \\
\hline PF06826 & Asp-Al_Ex & CL0064 & CPA_AT & Predicted Permease Membrane Region \\
\hline PF11700 & ATG22 & CL0015 & MFS & Vacuole effluxer Atg22 like \\
\hline PF03591 & AzIC & & & AzIC protein \\
\hline PF05437 & AzID & & & Branched-chain amino acid transport protein (AzID) \\
\hline PF02028 & BCCT & CL0062 & APC & BCCT, betaine/carnitine/choline family transporter \\
\hline PF03594 & BenE & CL0062 & APC & Benzoate membrane transport protein \\
\hline PF05525 & Branch_AA_trans & CL0062 & APC & Branched-chain amino acid transport protein \\
\hline PF03092 & BT1 & CL0015 & MFS & BT1 family \\
\hline PF05232 & BTP & & & Chlorhexidine efflux transporter \\
\hline PF03596 & Cad & CL0292 & LysE & Cadmium resistance transporter \\
\hline PF01545 & Cation_efflux & & & Cation efflux family \\
\hline PF09490 & CbtA & & & Probable cobalt transporter subunit (CbtA) \\
\hline PF03040 & CemA & & & CemA family \\
\hline PF04515 & Choline_transpo & & & Plasma-membrane choline transporter \\
\hline PF02417 & Chromate_transp & & & Chromate transporter \\
\hline PF03600 & CitMHS & CL0182 & IT & Citrate transporter \\
\hline PF16980 & CitMHS_2 & CL0182 & IT & Putative citrate transport \\
\hline PF02487 & CLN3 & & & CLN3 protein \\
\hline PF03601 & Cons_hypoth698 & CL0064 & CPA_AT & Conserved hypothetical protein 698 \\
\hline PF05425 & CopD & CL0430 & CopD_like & Copper resistance protein $\mathrm{D}$ \\
\hline PF08627 & CRT-like & CL0184 & DMT & CRT-like, chloroquine-resistance transporter-like \\
\hline PF16965 & CSG2 & CL0184 & DMT & Ceramide synthase regulator \\
\hline
\end{tabular}




\begin{tabular}{|c|c|c|c|c|}
\hline PF02554 & CstA & CL0062 & APC & Carbon starvation protein CstA \\
\hline PF13722 & CstA_5TM & & & 5TM C-terminal transporter carbon starvation CstA \\
\hline PF04145 & Ctr & & & Ctr copper transporter family \\
\hline PF06808 & DctM & CL0182 & IT & Tripartite ATP-independent periplasmic transporter, DctM component \\
\hline PF04290 & DctQ & & & Tripartite ATP-independent periplasmic transporters, DctQ component \\
\hline PF03605 & DcuA_DcuB & CL0182 & IT & Anaerobic c4-dicarboxylate membrane transporter \\
\hline PF03606 & DcuC & CL0182 & IT & C4-dicarboxylate anaerobic carrier \\
\hline PF04342 & DMT_6 & CL0184 & DMT & Putative member of DMT superfamily (DUF486) \\
\hline PF04657 & DMT_YdcZ & CL0184 & DMT & Putative inner membrane exporter, $\mathrm{YdcZ}$ \\
\hline PF02683 & DsbD & CL0292 & LysE & Cytochrome $\mathrm{C}$ biogenesis protein transmembrane region \\
\hline PF13386 & DsbD_2 & CL0292 & LysE & Cytochrome $\mathrm{C}$ biogenesis protein transmembrane region \\
\hline PF06237 & DUF1011 & & & Protein of unknown function (DUF1011) \\
\hline PF07854 & DUF1646 & CL0182 & IT & Protein of unknown function (DUF1646) \\
\hline PF09843 & DUF2070 & & & Predicted membrane protein (DUF2070) \\
\hline PF01595 & DUF21 & & & Cyclin $\mathrm{M}$ transmembrane $\mathrm{N}$-terminal domain \\
\hline PF09930 & DUF2162 & & & Predicted transporter (DUF2162) \\
\hline PF10027 & DUF2269 & CL0430 & CopD_like & Predicted integral membrane protein (DUF2269) \\
\hline PF10101 & DUF2339 & & & Predicted membrane protein (DUF2339) \\
\hline PF10821 & DUF2567 & & & Protein of unknown function (DUF2567) \\
\hline PF11168 & DUF2955 & CL0307 & FUSC & Protein of unknown function (DUF2955) \\
\hline PF11377 & DUF3180 & & & Protein of unknown function (DUF3180) \\
\hline PF11893 & DUF3413 & & & Domain of unknown function (DUF3413) \\
\hline PF04165 & DUF401 & CL0182 & IT & Protein of unknown function (DUF401) \\
\hline PF13664 & DUF4149 & CL0430 & CopD_like & Domain of unknown function (DUF4149) \\
\hline PF15860 & DUF4728 & CL0347 & Tetraspannin & Domain of unknown function (DUF4728) \\
\hline PF04332 & DUF475 & CL0292 & LysE & Protein of unknown function (DUF475) \\
\hline PF15962 & DUF4765 & & & Domain of unknown function (DUF4765) \\
\hline PF05684 & DUF819 & CL0064 & CPA_AT & Protein of unknown function (DUF819) \\
\hline PF06166 & DUF979 & & & Protein of unknown function (DUF979) \\
\hline PF00892 & EamA & CL0184 & DMT & EamA-like transporter family \\
\hline PF13536 & EmrE & CL0184 & DMT & Putative multidrug resistance efflux transporter \\
\hline PF00810 & ER_lumen_recept & CL0141 & MtN3-like & ER lumen protein retaining receptor \\
\hline PF04346 & Euth & & & Ethanolamine utilisation protein, EutH \\
\hline PF03124 & EXS & CL0182 & IT & EXS family \\
\hline PF01770 & Folate_carrier & CL0015 & MFS & Reduced folate carrier \\
\hline PF06963 & FPN1 & CL0015 & MFS & Ferroportin1 (FPN1) \\
\hline PF03239 & FTR1 & CL0292 & LysE & Iron permease FTR1 family \\
\hline PF04632 & FUSC & CL0307 & FUSC & Fusaric acid resistance protein family \\
\hline PF12805 & FUSC-like & CL0307 & FUSC & FUSC-like inner membrane protein yccS \\
\hline PF13515 & FUSC_2 & CL0307 & FUSC & Fusaric acid resistance protein-like \\
\hline PF07670 & Gate & & & Nucleoside recognition \\
\hline PF03323 & GerA & & & Bacillus/Clostridium GerA spore germination protein \\
\hline PF03616 & Glt_symporter & CL0064 & CPA_AT & Sodium/glutamate symporter \\
\hline PF02447 & GntP_permease & CL0182 & IT & GntP family permease \\
\hline PF04138 & GtrA & & & GtrA-like protein \\
\hline PF00955 & HCO3_cotransp & CL0062 & APC & HCO3- transporter family \\
\hline PF04982 & HPP & CL0307 & FUSC & HPP family \\
\hline PF16954 & HRG & & & Haem-transporter, endosomal/lysosomal, haem-responsive gene \\
\hline PF04955 & HupE_UreJ & CL0292 & LysE & HupE / UreJ protein \\
\hline PF13795 & HupE_UreJ_2 & CL0292 & LysE & HupE / UreJ protein \\
\hline
\end{tabular}




\begin{tabular}{|c|c|c|c|c|}
\hline PF10688 & Imp-YgjV & & & Bacterial inner membrane protein \\
\hline PF04120 & Iron_permease & & & Low affinity iron permease \\
\hline PF03812 & KdgT & CL0064 & CPA_AT & 2-keto-3-deoxygluconate permease \\
\hline PF02705 & K_trans & CL0062 & APC & $\mathrm{K}+$ potassium transporter \\
\hline PF02652 & Lactate_perm & CL0182 & IT & L-lactate permease \\
\hline PF01306 & LacY_symp & CL0015 & MFS & LacY proton/sugar symporter \\
\hline PF07766 & LETM1 & & & LETM1-like protein \\
\hline PF04791 & LMBR1 & & & LMBR1-like membrane protein \\
\hline PF04172 & $\operatorname{LrgB}$ & & & LrgB-like family \\
\hline PF01810 & LysE & CL0292 & LysE & LysE type translocator \\
\hline PF03956 & Lys_export & CL0064 & CPA_AT & Lysine exporter LysO \\
\hline PF03817 & MadL & & & Malonate transporter MadL subunit \\
\hline PF03818 & MadM & & & Malonate/sodium symporter MadM subunit \\
\hline PF01914 & MarC & CL0292 & LysE & MarC family integral membrane protein \\
\hline PF01554 & MatE & CL0222 & MviN_MATE & MatE \\
\hline PF03547 & Mem_trans & CL0064 & CPA_AT & Membrane transport protein \\
\hline PF10457 & MENTAL & & & Cholesterol-capturing domain \\
\hline PF07690 & MFS_1 & CL0015 & MFS & Major Facilitator Superfamily \\
\hline PF12832 & MFS_1_like & CL0015 & MFS & MFS_1 like family \\
\hline PF13347 & MFS_2 & CL0015 & MFS & MFS/sugar transport protein \\
\hline PF05977 & MFS 3 & CL0015 & MFS & Transmembrane secretion effector \\
\hline PF06779 & MFS_4 & CL0015 & MFS & Uncharacterised MFS-type transporter YbfB \\
\hline PF05631 & MFS_5 & CL0015 & MFS & Sugar-tranasporters, $12 \mathrm{TM}$ \\
\hline PF16983 & MFS_MOT1 & CL0062 & APC & Molybdate transporter of MFS superfamily \\
\hline PF07672 & MFS_Mycoplasma & CL0015 & MFS & Mycoplasma MFS transporter \\
\hline PF01769 & MgtE & & & Divalent cation transporter \\
\hline PF05653 & Mg_trans_NIPA & CL0184 & DMT & Magnesium transporter NIPA \\
\hline PF00153 & Mito carr & & & Mitochondrial carrier protein \\
\hline PF03094 & Mlo & & & Mlo family \\
\hline PF10296 & MMM1 & & & Maintenance of mitochondrial morphology protein 1 \\
\hline PF03176 & MMPL & CL0322 & RND_permease & MMPL family \\
\hline PF02659 & Mntp & CL0292 & LysE & Putative manganese efflux pump \\
\hline PF03650 & MPC & CL0141 & MtN3-like & Mitochondrial pyruvate carriers \\
\hline PF03820 & Mtc & & & Tricarboxylate carrier \\
\hline PF03083 & MtN3_slv & CL0141 & MtN3-like & Sugar efflux transporter for intercellular exchange \\
\hline PF03821 & Mtp & CL0347 & Tetraspannin & Golgi 4-transmembrane spanning transporter \\
\hline PF00893 & Multi_Drug_Res & CL0184 & DMT & Small Multidrug Resistance protein \\
\hline PF03023 & MurJ & CL0222 & MviN_MATE & Lipid II flippase MurJ \\
\hline PF01235 & Na_Ala_symp & CL0062 & APC & Sodium:alanine symporter family \\
\hline PF01699 & $\mathrm{Na}{ }_{-} \mathrm{C} a \_\mathrm{ex}$ & & & Sodium/calcium exchanger protein \\
\hline PF03553 & $\mathrm{Na} \_\mathrm{H} \_$antiporter & CL0182 & IT & $\mathrm{Na}+/ \mathrm{H}+$ antiporter family \\
\hline PF06965 & Na_H_antiport_1 & CL0064 & CPA_AT & $\mathrm{Na}+/ \mathrm{H}+$ antiporter 1 \\
\hline PF13726 & $\mathrm{Na} \mathrm{H}_{\text {antiport }} 2$ & CL0182 & IT & $\mathrm{Na}+\mathrm{H}+$ antiporter family \\
\hline PF07399 & $\mathrm{Na} \_\mathrm{H}$ _antiport_3 & CL0182 & IT & Putative $\mathrm{Na}+/ \mathrm{H}+$ antiporter \\
\hline PF00999 & $\mathrm{Na}{ }_{2} \mathrm{H}_{-}$Exchanger & CL0064 & CPA_AT & Sodium/hydrogen exchanger family \\
\hline PF02690 & $\mathrm{Na}$ _Pi_cotrans & & & $\mathrm{Na}+/ \mathrm{Pi}$-cotransporter \\
\hline PF00939 & $\mathrm{Na}$ _sulph_symp & CL0182 & IT & Sodium:sulfate symporter transmembrane region \\
\hline PF06450 & NhaB & CL0182 & IT & Bacterial $\mathrm{Na}+/ \mathrm{H}+$ antiporter $\mathrm{B}(\mathrm{NhaB})$ \\
\hline PF03824 & $\mathrm{NicO}$ & CL0292 & LysE & High-affinity nickel-transport protein \\
\hline PF04973 & NMN_transporter & & & Nicotinamide mononucleotide transporter \\
\hline
\end{tabular}




\begin{tabular}{|c|c|c|c|c|}
\hline PF06813 & Nodulin-like & CL0015 & MFS & Nodulin-like \\
\hline PF01566 & Nramp & CL0062 & APC & Natural resistance-associated macrophage protein \\
\hline PF01733 & Nucleoside_tran & CL0015 & MFS & Nucleoside transporter \\
\hline PF03825 & Nuc_H_symport & CL0015 & MFS & Nucleoside $\mathrm{H}+$ symporter \\
\hline PF04142 & Nuc_sug_transp & CL0184 & DMT & Nucleotide-sugar transporter \\
\hline PF03137 & OATP & CL0015 & MFS & Organic Anion Transporter Polypeptide (OATP) family \\
\hline PF16955 & OFeT_1 & CL0292 & LysE & Ferrous iron uptake permease, iron-lead transporter \\
\hline PF03169 & OPT & & & OPT oligopeptide transporter protein \\
\hline PF04756 & OST3_OST6 & CL0172 & Thioredoxin & OST3 / OST6 family, transporter family \\
\hline PF15048 & OSTbeta & & & Organic solute transporter subunit beta protein \\
\hline PF02460 & Patched & CL0322 & RND_permease & Patched family \\
\hline PF16933 & PelG & & & Putative exopolysaccharide Exporter (EPS-E) \\
\hline PF01384 & $\mathrm{PHO} 4$ & & & Phosphate transporter family \\
\hline PF04193 & PQ-loop & CL0141 & MtN3-like & PQ loop repeat \\
\hline PF00854 & PTR2 & CL0015 & MFS & POT family \\
\hline PF02378 & PTS_EIIC & CL0493 & PTS_EIIC & Phosphotransferase system, EIIC \\
\hline PF13303 & PTS_EIIC_2 & CL0493 & PTS_EIIC & Phosphotransferase system, EIIC \\
\hline PF03209 & PUCC & CL0015 & MFS & PUCC protein \\
\hline PF16913 & PUNUT & CL0184 & DMT & Purine nucleobase transmembrane transport \\
\hline PF14752 & RBP_receptor & & & Retinol binding protein receptor \\
\hline PF04506 & Rft-1 & CL0222 & MviN_MATE & Rft protein \\
\hline PF06379 & Rhat & CL0184 & DMT & L-rhamnose-proton symport protein (RhaT) \\
\hline PF04479 & RTA1 & & & RTA1 like protein \\
\hline PF01758 & SBF & CL0064 & CPA_AT & Sodium Bile acid symporter family \\
\hline PF13593 & SBF_like & CL0064 & CPA_AT & SBF-like CPA transporter family (DUF4137) \\
\hline PF05982 & Sbt_1 & CL0064 & CPA_AT & $\mathrm{Na}$ +-dependent bicarbonate transporter superfamily \\
\hline PF02667 & SCFA_trans & CL0182 & IT & Short chain fatty acid transporter \\
\hline PF00375 & SDF & & & Sodium:dicarboxylate symporter family \\
\hline PF13630 & Sdpl & & & Sdpl/YhfL protein family \\
\hline PF02355 & SecD_SecF & CL0322 & RND_permease & Protein export membrane protein \\
\hline PF11139 & SfLAP & CL0292 & LysE & Sap, sulfolipid-1-addressing protein \\
\hline PF13965 & SID-1_RNA_chan & CL0192 & GPCR_A & dsRNA-gated channel SID-1 \\
\hline PF03842 & Silic_transp & & & Silicon transporter \\
\hline PF03522 & SLC12 & & & Solute carrier family 12 \\
\hline PF06027 & SLC35F & CL0184 & DMT & Solute carrier family 35 \\
\hline PF09335 & SNARE_asSOC & & & SNARE associated Golgi protein \\
\hline PF00209 & SNF & CL0062 & APC & Sodium:neurotransmitter symporter family \\
\hline PF03619 & Solute_trans_a & & & Organic solute transporter Ostalpha \\
\hline PF09546 & Spore_III_AE & & & Stage III sporulation protein AE (spore_III_AE) \\
\hline PF03845 & Spore_permease & CL0062 & APC & Spore germination protein \\
\hline PF13782 & SpoVAB & & & Stage $V$ sporulation protein $A B$ \\
\hline PF00474 & SSF & CL0062 & APC & Sodium:solute symporter family \\
\hline PF12349 & Sterol-sensing & CL0322 & RND_permease & Sterol-sensing domain of SREBP cleavage-activation \\
\hline PF00083 & Sugar_tr & CL0015 & MFS & Sugar (and other) transporter \\
\hline PF06800 & Sugar_transport & CL0184 & DMT & Sugar transport protein \\
\hline PF00916 & Sulfate_transp & CL0062 & APC & Sulfate permease family \\
\hline PF04143 & Sulf_transp & & & Sulphur transport \\
\hline PF01925 & TauE & CL0292 & LysE & Sulfite exporter TauE/SafE \\
\hline PF01970 & TctA & & & Tripartite tricarboxylate transporter TctA family \\
\hline PF03741 & TerC & CL0292 & LysE & Integral membrane protein TerC family \\
\hline
\end{tabular}




\begin{tabular}{|c|c|c|c|c|}
\hline PF06738 & ThrE & CL0470 & UMP_1 & Putative threonine/serine exporter \\
\hline PF12821 & ThrE_2 & CL0470 & UMP_1 & Threonine/Serine exporter, ThrE \\
\hline PF03219 & TLC & CL0015 & MFS & TLC ATP/ADP transporter \\
\hline PF07857 & TMEM144 & CL0184 & DMT & Transmembrane family, TMEM144 of transporters \\
\hline PF10639 & TMEM234 & CL0184 & DMT & Putative transmembrane family 234 \\
\hline PF03647 & Tmemb_14 & & & Transmembrane proteins $14 \mathrm{C}$ \\
\hline PF03151 & TPT & CL0184 & DMT & Triose-phosphate Transporter family \\
\hline PF02133 & Transp_cyt_pur & CL0062 & APC & Permease for cytosine/purines, uracil, thiamine, allantoin \\
\hline PF06609 & TRI12 & CL0015 & MFS & Fungal trichothecene efflux pump (TRI12) \\
\hline PF03222 & Trp_Tyr_perm & CL0062 & APC & Tryptophan/tyrosine permease family \\
\hline PF03073 & TspO_MBR & & & Tspo/MBR family \\
\hline PF08449 & UAA & CL0184 & DMT & UAA transporter family \\
\hline PF05978 & UNC-93 & CL0015 & MFS & Ion channel regulatory protein UNC-93 \\
\hline PF01169 & UPF0016 & CL0292 & LysE & Uncharacterized protein family UPF0016 \\
\hline PF02694 & UPF0060 & CL0184 & DMT & Uncharacterised BCR, YnfA/UPF0060 family \\
\hline PF03653 & UPF0093 & CL0430 & CopD_like & Uncharacterised protein family (UPF0093) \\
\hline PF07168 & Ureide_permease & CL0184 & DMT & Ureide permease \\
\hline PF03253 & UT & & & Urea transporter \\
\hline PF04892 & Vanz & & & VanZ like family \\
\hline PF03631 & Virul_fac_BrkB & & & Virulence factor BrkB \\
\hline PF01988 & VIT1 & & & VIT family \\
\hline PF00654 & Voltage_CLC & & & Voltage gated chloride channel \\
\hline PF00860 & Xan_ur_permease & CL0062 & APC & Permease family \\
\hline PF09815 & XK-related & & & XK-related protein \\
\hline PF03733 & YccF & & & Inner membrane component domain \\
\hline PF02325 & YGGT & & & YGGT family \\
\hline PF02588 & YitT_membrane & & & Uncharacterised 5xTM membrane BCR, YitT family COG1284 \\
\hline PF02535 & Zip & CL0184 & DMT & ZIP Zinc transporter \\
\hline
\end{tabular}


Supplementary Table 2

False positive hits or incorrectly annotated human sequences found in our search. Gene symbol and protein name shown based on UniProt data. Most similar (highest scoring) TCDB families/subfamilies and Pfam families are shown.

\begin{tabular}{|c|c|c|c|c|c|c|c|}
\hline UniProt ID & Gene symbol & TCDB family & $\begin{array}{l}\text { TCDB } \\
\text { score }\end{array}$ & Pfam family & $\begin{array}{l}\text { Pfam } \\
\text { score }\end{array}$ & Protein name & Remarks \\
\hline B7Z8S2 & & 1.A.11.4 & 176.1 & Ammonium_transp & 69.7 & $\begin{array}{l}\text { cDNA FL52981, moderately similar to Homo sapiens } \\
\text { Rhesus blood group, B glycoprotein (RHBG), mRNA }\end{array}$ & $\begin{array}{l}\text { Seems like a splice variant of RHBG_HUMAN, with the middle of the protein } \\
\text { missing. }\end{array}$ \\
\hline P18577 & RHCE & 1.A.11.4 & 506.9 & Ammonium_transp & 203 & Blood group $\mathrm{Rh}(\mathrm{CE})$ polypeptide & $\begin{array}{l}\text { Defines the Rh blood group, likely has a structural role in assembling the gas } \\
\text { metabolon [PMID:18832935] }\end{array}$ \\
\hline Q02161 & RHD & 1.A.11.4 & 509.3 & Ammonium_transp & 201.3 & Blood group $\mathrm{Rh}(\mathrm{D})$ polypeptide & $\begin{array}{l}\text { Defines the Rh blood group, likely has a structural role in assembling the gas } \\
\text { metabolon [PMID:18832935] }\end{array}$ \\
\hline Q8IXB1 & DNAJC10 & 1.A.76 & 36.5 & OST3_OST6 & 53.3 & DnaJ homolog subfamily $\mathrm{C}$ member 10 & $\begin{array}{l}\text { Characterized enzyme. Part of this protein shows similarity to part of the } \\
\text { OST3_OST6 Pfam domain, probably because the OST3_OST6 model also contains a } \\
\text { (partial) thioredoxin domain, because the hits overlaps with the Thioredoxin } \\
\text { domain hit annotated on the Pfam web site. }\end{array}$ \\
\hline P13667 & PDIA4 & 1.A.76.1 & 56.7 & OST3_OST6 & 57.3 & Protein disulfide-isomerase A4 & $\begin{array}{l}\text { Characterized enzyme. Similarly to protein Q8IXB1, this protein also gives a hit for } \\
\text { the OST3_OST6 domain that overlaps with the hit for a Thioredoxin domain } \\
\text { annotated as shown on the website for this sequence in Pfam. }\end{array}$ \\
\hline Q14554 & PDIA5 & 1.A.76.1 & 53.3 & OST3_OST6 & 57.4 & Protein disulfide-isomerase A5 & Characterized enzyme. The same case as for proteins Q8IXB1 and P13667. \\
\hline Q6ZUX1 & & 1.A.112 & 72.5 & DUF21 & 17.6 & cDNA FL43252 fis, clone HEART2006909 & Only similar proteins in UniProt are bacterial proteins with $>50 \%$ identity. \\
\hline B4DIU4 & & 2.A.1.1 & 47.7 & Sugar_tr & 62 & $\begin{array}{l}\text { cDNA FL50540, highly similar to Solute carrier family } 2 \text {, } \\
\text { facilitated glucose transporter member } 5\end{array}$ & $\begin{array}{l}\text { First } 98 \text { amino acids of } 113 \text { are identical to human SLC2A5, so probably a fragment } \\
\text { or splice variant. }\end{array}$ \\
\hline $\begin{array}{l}\text { A0A024R4M } \\
7\end{array}$ & & 2.A.3.3 & 90.5 & & 0 & HCG1658540, isoform CRA_a & $\begin{array}{l}\text { The first } 195 \text { aa of this } 205 \text {-aa sequence shows } 53.3 \% \text { identity to a segment of } \\
\text { human SLC7A3. Contains } 5 \text { predicted TM helices according to UniProt, so likely is } \\
\text { not a complete transporter sequence. BLAST search returns mammalian sequences } \\
\text { with the highest identity of } 78.7 \% \text {. }\end{array}$ \\
\hline Q9NWI3 & & 2.A.3.8 & 194.7 & AA_permease_2 & 39 & cDNA FL20839 fis, clone ADKA02346 & $\begin{array}{l}\text { The C-terminal } 185 \text { aa of this } 370 \text {-aa sequence is identical to the C-terminus of } \\
\text { human SLC7A10. }\end{array}$ \\
\hline Q75T53 & & 2.A.5.4 & 359 & Zip & 226.4 & Uncharacterized protein & $\begin{array}{l}\text { BLAST search showed hits with } 50-60 \% \text { sequence identity from mites/ticks, and } \\
\text { these were the most similar hits. Possibly not a human sequence. }\end{array}$ \\
\hline P04035 & HMGCR & 2.A.6.6 & 530.9 & Sterol-sensing & 63.1 & 3-hydroxy-3-methylglutaryl-coenzyme A reductase & $\begin{array}{l}\text { A well-characterized enzyme showing similarity to TC \#2.A.6.6, Patched proteins, } \\
\text { and also containing the Sterol-sensing domain. Also, the rate-limiting enzyme in } \\
\text { cholesterol biosynthesis highly expressed in liver [25650254]. }\end{array}$ \\
\hline 043600 & & 2.A.17.1 & 58.9 & PTR2 & 28.8 & Erythroid differentiation-related factor 2 (Fragment) & $\begin{array}{l}\text { Shows highest similarity ( } 96.2 \% \text { identity) to inner segments of bacterial proteins, so } \\
\text { likely not a human protein. }\end{array}$ \\
\hline Q86YK3 & $\begin{array}{l}\text { STK4/SLC36A } \\
\text { L }\end{array}$ & 2.A.18.8 & 61.2 & & 0 & $\begin{array}{l}\text { Kinase/transmembrane domain fusion protein } \\
\text { (Fragment) }\end{array}$ & $\begin{array}{l}\text { Proteins in this family without the Aa_trans Pfam domain are likely not } \\
\text { transmembrane. Missing the canonical transporter domain of the family, and } \\
\text { contains only } 2 \text { TMHs according to UniProt annotations. }\end{array}$ \\
\hline Q8WXG9 & ADGRV1 & 2.A.19.3 & 638.8 & & 0 & Adhesion G-protein coupled receptor V1 & $\begin{array}{l}\text { SLC8-similar proteins not containing the Pfam domain Na_Ca_ex. This protein is a } \\
\text { false positive, which has been selected because it contain Calx-beta Pfam domains } \\
\text { similarly to SLC8A1-3 proteins. However, it is a known GPCR. }\end{array}$ \\
\hline Q86XX4 & FRAS1 & 2.A.19.3 & 134.9 & & 0 & Extracellular matrix protein FRAS1 & $\begin{array}{l}\text { SLC8-similar proteins not containing the Pfam domain Na_Ca_ex. This protein is a } \\
\text { false positive, which has been selected because it contain Calx-beta Pfam domains } \\
\text { similarly to SLC8A1-3 proteins. However, it is a single-TMH protein with no known } \\
\text { transporter function. }\end{array}$ \\
\hline Q5SZK8 & FREM2 & 2.A.19.3 & 145 & & 0 & FRAS1-related extracellular matrix protein 2 & $\begin{array}{l}\text { SLC8-similar proteins not containing the Pfam domain Na_Ca_ex. This protein is a } \\
\text { false positive, which has been selected because it contain Calx-beta Pfam domains } \\
\text { similarly to SLC8A1-3 proteins. However, it is a single-TMH protein with no known } \\
\text { transporter function. }\end{array}$ \\
\hline
\end{tabular}




\begin{tabular}{|c|c|c|c|c|c|c|c|}
\hline POC091 & FREM3 & 2.A.19.3 & 92.6 & & 0 & FRAS1-related extracellular matrix protein 3 & $\begin{array}{l}\text { SLC8-similar proteins not containing the Pfam domain Na_Ca_ex. This protein is a } \\
\text { false positive, which has been selected because it contain Calx-beta Pfam domains } \\
\text { similarly to SLC8A1-3 proteins. However, it is a single-TMH protein with no known } \\
\text { transporter function. }\end{array}$ \\
\hline B4E2E9 & & 2.A.22.2 & 154.3 & SNF & 113.8 & $\begin{array}{l}\text { cDNA FL51458, highly similar to Sodium- and chloride- } \\
\text { dependent neutral andbasic amino acid transporter } \\
\mathrm{B}(0+)\end{array}$ & $\begin{array}{l}\text { This } 149 \text {-aa sequence shows } 92 \% \text { identity to a segment of human SLC6A14, so is } \\
\text { likely a fragment. }\end{array}$ \\
\hline Q8N7R6 & & 2.A.29.4 & 108.8 & & 0 & $\begin{array}{l}\text { CDNA FL } 40434 \text { fis, clone TESTI2039353, moderately } \\
\text { similar to MITOCHONDRIAL PHOSPHATE CARRIER } \\
\text { PROTEIN }\end{array}$ & $\begin{array}{l}\text { Seems to contain only a single MCF repeat (UniProt). BLAST search returns } \\
\text { vertebrate sequences, highest similarity was } 81.9 \% \text { identity with sequence F7I611. }\end{array}$ \\
\hline B4DSH6 & & 2.A.29.14 & 225.1 & Mito_carr & 118.4 & $\begin{array}{l}\text { cDNA FL53093, moderately similar to Mus musculus } \\
\text { solute carrier family } 25 \text {, member } 23 \text { (Slc25a23), mRNA }\end{array}$ & $\begin{array}{l}\text { Seems to contain only two MCF repeats (UniProt). An alignment with human } \\
\text { SLC25A44, SLC25A18 and mouse SIc25a23 and human SLC25A23 showed that this } \\
\text { sequence is basically identical to the C-terminal half of Q96H78 (human SLC25A44), } \\
\text { with a larger stretch of } \sim 100 \text { residues missing. So probably an alternatively spliced } \\
\text { variant. }\end{array}$ \\
\hline Q13717 & & 2.A.31.1 & 689.5 & HCO3_cotransp & 438.5 & Anion exchange protein 3 (Fragment) & $\begin{array}{l}\text { Similar ( } 92.8 \% \text { identity) to the C-terminal part of SLC4A3, also does not start with a } \\
\text { methionine. }\end{array}$ \\
\hline B3KS22 & & 2.A.36.1 & 279.9 & $\mathrm{Na} \_\mathrm{H} \_$Exchanger & 130 & HCG2015407 & $\begin{array}{l}96.6 \% \text { identical to the gorilla protein A0A2I2YMF4, however, the gorilla protein is } \\
\text { much larger, and this human sequence possibly contains a half transporter. }\end{array}$ \\
\hline Q9BXG1 & & 2.A.40.7 & 380.5 & Xan_ur_permease & 118.8 & p41 & $\begin{array}{l}\text { BLAST search gives } \sim 90 \% \text { identical hits from Leuconostoc lactis (Guanine permease), } \\
\text { so probably not a human protein. }\end{array}$ \\
\hline Q59FC0 & & 2.A.48 & 115.7 & Folate_carrier & 69.8 & Solute carrier family 19, member 2 variant (Fragment) & $\begin{array}{l}\text { The last } 89 \text { aa of this } 125 \text {-aa sequence is identical to human SLC19A2, might be a } \\
\text { fragment of a splice variant. }\end{array}$ \\
\hline B4DE56 & & 2.A.49.2 & 214 & Voltage_CLC & 75.5 & $\begin{array}{l}\text { cDNA FL59180, moderately similar to Chloride channel } \\
\text { protein CIC-Ka }\end{array}$ & $\begin{array}{l}\text { High similarity to the inner segment of human CIC-Ka (P51800, } 76.8 \% \text { identity, but } \\
\text { C-terminal region almost identical), therefore probably a fragment. }\end{array}$ \\
\hline B4EOR8 & & 2.A.90 & 74.4 & RBP_receptor & 170.2 & cDNA FLJ60210 & $\begin{array}{l}\text { Seems to match } 3 \text { TMHs of the region encoded by the RBP_receptor Pfam family. } \\
\text { The full domain contains } 9 \text { TMHs, so this sequence is likely to be a fragment. BLAST } \\
\text { searches returned no significantly similar hits in human. }\end{array}$ \\
\hline B7ZMG3 & KIAA1529 & 2.A.90.2 & 84.9 & RBP_receptor & 128.9 & KIAA1529 protein & $\begin{array}{l}\text { Seems to match a non-TM region of the RBP_receptor Pfam domain. Identical to } \\
\text { human CCDC180 with an extra } 139 \text { aa at the N-terminus, which is a secreted protein } \\
\text { according to UniProt annotations. }\end{array}$ \\
\hline A4D146 & LOC402642 & 2.A.100 & 61.5 & FPN1 & 60.4 & Solute carrier family 40 protein & $\begin{array}{l}\text { Short protein ( } 167 \text { aa), might be a fragment. Contains a segment of } 59 \text { aa } 69.5 \% \\
\text { identical to zebrafish SLC4OA1-like sequence (AOA2R8Q2S9), and a segment } 82 \text { aa } \\
53.7 \% \text { identical to human SLC40A1. BLAST search returns SLC4OA1-like sequences } \\
\text { from mammals and vertebrates. }\end{array}$ \\
\hline Q6J4J2 & & 9. B.27.1 & 69 & SNARE_assoc & 26.5 & Inflammatory related protein & $\begin{array}{l}\text { Most similar proteins are bacteria ( } 95.0 \% \text { identity with } \mathrm{N} \text {-terminal half of Q8XDY4), } \\
\text { so likely not a human protein. }\end{array}$ \\
\hline P49675 & STAR & 9. B.64 & 144.8 & & 0 & Steroidogenic acute regulatory protein, mitochondrial & Proteins in this family without the MENTAL Pfam domain are not transmembrane. \\
\hline P59095 & STARD6 & 9.B.64 & 76.1 & & 0 & StAR-related lipid transfer protein 6 & Proteins in this family without the MENTAL Pfam domain are not transmembrane. \\
\hline P24390 & KDELR1 & 9.B.191.1 & 285.2 & ER_lumen_recept & 193.5 & ER lumen protein-retaining receptor 1 & $\begin{array}{l}\text { Belongs to the family of KDEL receptor proteins, which are well-characterized } \\
\text { receptors. However, KDEL receptors show sequence similarity to SWEET } \\
\text { transporters. }\end{array}$ \\
\hline P33947 & KDELR2 & 9.B.191.1 & 278.3 & ER_lumen_recept & 188.8 & ER lumen protein-retaining receptor 2 & $\begin{array}{l}\text { Belongs to the family of KDEL receptor proteins, which are well-characterized } \\
\text { receptors. However, KDEL receptors show sequence similarity to SWEET } \\
\text { transporters. }\end{array}$ \\
\hline 043731 & KDELR3 & 9.B.191.1 & 258.8 & ER_lumen_recept & 180.1 & ER lumen protein-retaining receptor 3 & $\begin{array}{l}\text { Belongs to the family of KDEL receptor proteins, which are well-characterized } \\
\text { receptors. However, KDEL receptors show sequence similarity to SWEET } \\
\text { transporters. }\end{array}$ \\
\hline
\end{tabular}




\section{Supplementary Table 3}

Table of existing ("original"/classical) SLC transporters, showing correlation with TCDB families/subfamilies, Pfam families and PDB structures and structural folds. Gene symbol and protein name based on UniProt information are shown. Most similar (highest-scoring) TCDB families and subfamilies, as well as Pfam families are shown for each protein. The PDB structure from the pdb70 dataset that is most similar (highest-scoring) to each protein is shown, along with its fold family assignment by us, partly based on TCDB family names.

AbgT: p-Aminobenzoyl-glutamate Transporter family; Amt: Ammonium Transporter family; APC: Amino acid-Polyamine-Cation family; CDF: Cation Diffusion Facilitator family; CNT: Concentrative Nucleoside Transporter family; Ctr: Copper Transporter family; DAACS: Dicarboxylate/Amino Acid:Cation (Na+ or H+) Symporter family; MATE: Multidrug And Toxic compound Extrusion family; MCF: Mitochondrial Carrier Family; MFS: Major Facilitator Superfamily; MgtE: Mg2+ transporter-E family; NAT: Nucleobase/Ascorbate Transporter or Nucleobase:Cation Symporter-2 (NCS2) family; NCX: Sodium/Calcium exchanger family; NhaA: Sodium/proton antiporter family; NST: Nucleoside-Sugar Transporter family; PiT: Type III Sodium/phosphate cotransporter family; SWEET: Sugar Will Eventually be Transported family.; ZIP: Zrt/Irt-like Transporter family.

\begin{tabular}{|c|c|c|c|c|c|}
\hline Family name & UniProt ID & Gene symbol & TCDB family & TCDB score & Pfam family \\
\hline SLC1 & P43005 & SLC1A1 & 2.A.23.2 & 779.7 & SDF \\
\hline SLC1 & P43004 & SLC1A2 & 2.A.23.2 & 819.1 & SDF \\
\hline SLC1 & P43003 & SLC1A3 & 2.A.23.2 & 838.8 & SDF \\
\hline SLC1 & P43007 & SLC1A4 & 2.A.23.3 & 896 & SDF \\
\hline SLC1 & Q15758 & SLC1A5 & 2.A.23.3 & 935.5 & SDF \\
\hline SLC1 & P48664 & SLC1A6 & 2.A.23.2 & 793.7 & SDF \\
\hline SLC1 & 000341 & SLC1A7 & 2.A.23.2 & 790.4 & SDF \\
\hline SLC2 & P11166 & SLC2A1 & 2.A.1.1 & 470.6 & Sugar_tr \\
\hline SLC2 & P11168 & SLC2A2 & 2.A.1.1 & 496.4 & Sugar_tr \\
\hline SLC2 & P11169 & SLC2A3 & 2.A.1.1 & 469.2 & Sugar_tr \\
\hline SLC2 & P14672 & SLC2A4 & 2.A.1.1 & 456.4 & Sugar_tr \\
\hline SLC2 & P22732 & SLC2A5 & 2.A.1.1 & 426 & Sugar_tr \\
\hline SLC2 & Q9UGQ3 & SLC2A6 & 2.A.1.1 & 401.3 & Sugar_tr \\
\hline SLC2 & Q6PXP3 & SLC2A7 & 2.A.1.1 & 414.9 & Sugar_tr \\
\hline SLC2 & Q9NY64 & SLC2A8 & 2.A.1.1 & 441.7 & Sugar_tr \\
\hline SLC2 & Q9NRM0 & SLC2A9 & 2.A.1.1 & 385.5 & Sugar_tr \\
\hline SLC2 & 095528 & SLC2A10 & 2.A.1.1 & 393.3 & Sugar_tr \\
\hline SLC2 & Q9BYW1 & SLC2A11 & 2.A.1.1 & 316.1 & Sugar_tr \\
\hline SLC2 & Q8TD20 & SLC2A12 & 2.A.1.1 & 456.8 & Sugar_tr \\
\hline SLC2 & Q96QE2 & SLC2A13 & 2.A.1.1 & 532.4 & Sugar_tr \\
\hline SLC2 & Q8TDB8 & SLC2A14 & 2.A.1.1 & 458.9 & Sugar_tr \\
\hline SLC4 & P02730 & SLC4A1 & 2.A.31.1 & 1661.6 & HCO3_cotransp \\
\hline SLC4 & P04920 & SLC4A2 & 2.A.31.1 & 2333.9 & HCO3_cotransp \\
\hline SLC4 & P48751 & SLC4A3 & 2.A.31.1 & 2263.2 & HCO3_cotransp \\
\hline SLC4 & Q9Y6R1 & SLC4A4 & 2.A.31.2 & 1745.2 & HCO3_cotransp \\
\hline SLC4 & Q9BY07 & SLC4A5 & 2.A.31.2 & 1620.8 & HCO3_cotransp \\
\hline SLC4 & Q9Y6M7 & SLC4A7 & 2.A.31.2 & 1870.8 & HCO3_cotransp \\
\hline SLC4 & Q2Y0W8 & SLC4A8 & 2.A.31.2 & 1807.3 & HCO3_cotransp \\
\hline SLC4 & Q96Q91 & SLC4A9 & 2.A.31.2 & 1379.3 & HCO3_cotransp \\
\hline SLC4 & Q6U841 & SLC4A10 & 2.A.31.2 & 1834.1 & HCO3_cotransp \\
\hline SLC4 & Q8NBS3 & SLC4A11 & 2.A.31.4 & 2155.1 & HCO3_cotransp \\
\hline SLC5 & P13866 & SLC5A1 & 2.A.21.3 & 884.6 & SSF \\
\hline SLC5 & P31639 & SLC5A2 & 2.A.21.3 & 859.4 & SSF \\
\hline SLC5 & P53794 & SLC5A3 & 2.A.21.3 & 867.7 & SSF \\
\hline SLC5 & Q9NY91 & SLC5A4 & 2.A.21.3 & 843.1 & SSF \\
\hline SLC5 & Q92911 & SLC5A5 & 2.A.21.5 & 935.7 & SSF \\
\hline
\end{tabular}

\begin{tabular}{|c|c|c|c|}
\hline Pfam score & Protein name & Closest PDB & Structural fold \\
\hline 438.5 & Excitatory amino acid transporter 3 & $6 r v x B$ & DAACS \\
\hline 442 & Excitatory amino acid transporter 2 & $6 r v x B$ & DAACS \\
\hline 445.2 & Excitatory amino acid transporter 1 & $6 r v x B$ & DAACS \\
\hline 400.3 & Neutral amino acid transporter A & 6rvxB & DAACS \\
\hline 399 & Neutral amino acid transporter $\mathrm{B}(0)$ & $6 r v x B$ & DAACS \\
\hline 434.3 & Excitatory amino acid transporter 4 & $6 r v x B$ & DAACS \\
\hline 427.1 & Excitatory amino acid transporter 5 & $6 r v x B$ & DAACS \\
\hline 538.4 & Solute carrier family 2, facilitated glucose transporter member 1 & 6thaA & MFS \\
\hline 534 & Solute carrier family 2, facilitated glucose transporter member 2 & 5eqhA & MFS \\
\hline 522.6 & Solute carrier family 2 , facilitated glucose transporter member 3 & $4 z w 9 A$ & MFS \\
\hline 508.3 & Solute carrier family 2, facilitated glucose transporter member 4 & 4zw9A & MFS \\
\hline 465.8 & Solute carrier family 2, facilitated glucose transporter member 5 & 4yb9D & MFS \\
\hline 273.7 & Solute carrier family 2, facilitated glucose transporter member 6 & $4 \mathrm{j} 05 \mathrm{~A}$ & MFS \\
\hline 401.8 & Solute carrier family 2, facilitated glucose transporter member 7 & 4zw9A & MFS \\
\hline 338.6 & Solute carrier family 2, facilitated glucose transporter member 8 & 4zw9A & MFS \\
\hline 354.4 & Solute carrier family 2, facilitated glucose transporter member 9 & 4zw9A & MFS \\
\hline 240.2 & Solute carrier family 2, facilitated glucose transporter member 10 & $4 z w 9 A$ & MFS \\
\hline 313.5 & Solute carrier family 2, facilitated glucose transporter member 11 & 5eqhA & MFS \\
\hline 332.1 & Solute carrier family 2, facilitated glucose transporter member 12 & 4zw9A & MFS \\
\hline 378.5 & Proton myo-inositol cotransporter & 4zw9A & MFS \\
\hline 513.9 & Solute carrier family 2, facilitated glucose transporter member 14 & 4zw9A & MFS \\
\hline 655.2 & Band 3 anion transport protein & 4yzfA & NAT \\
\hline 693.2 & Anion exchange protein 2 & $6 \mathrm{caaB}$ & NAT \\
\hline 681.4 & Anion exchange protein 3 & $6 \mathrm{caaB}$ & NAT \\
\hline 784.8 & Electrogenic sodium bicarbonate cotransporter 1 & $6 \mathrm{caaB}$ & NAT \\
\hline 752.5 & Electrogenic sodium bicarbonate cotransporter 4 & $6 \mathrm{caaB}$ & NAT \\
\hline 811.3 & Sodium bicarbonate cotransporter 3 & $6 \mathrm{caaB}$ & NAT \\
\hline 820 & Electroneutral sodium bicarbonate exchanger 1 & $6 \mathrm{caaB}$ & NAT \\
\hline 707.3 & Anion exchange protein 4 & $6 c a a B$ & NAT \\
\hline 822.1 & Sodium-driven chloride bicarbonate exchanger & $6 \mathrm{caaB}$ & NAT \\
\hline 518 & Sodium bicarbonate transporter-like protein 11 & 6caaB & NAT \\
\hline 586.7 & Sodium/glucose cotransporter 1 & $2 \times q 2 \mathrm{~A}$ & APC \\
\hline 564.8 & Sodium/glucose cotransporter 2 & $2 \times q 2 A$ & APC \\
\hline 538.8 & Sodium/myo-inositol cotransporter & $2 \times q 2 A$ & APC \\
\hline 525.8 & Solute carrier family 5 member 4 & $2 \times q 2 \mathrm{~A}$ & APC \\
\hline 145.7 & Sodium/iodide cotransporter & $2 \times q 2 \mathrm{~A}$ & APC \\
\hline
\end{tabular}




\begin{tabular}{|c|c|c|c|c|c|c|c|c|c|}
\hline SLC5 & Q9Y289 & SLC5A6 & 2.A.21.5 & 955.3 & SSF & 131.7 & Sodium-dependent multivitamin transporter & $2 \times q 2 A$ & APC \\
\hline SLC5 & Q9GZV3 & SLC5A7 & 2.A.21.8 & 1189.2 & SSF & 120.6 & High affinity choline transporter 1 & $2 \times 92 \mathrm{~A}$ & APC \\
\hline SLC5 & Q8N695 & SLC5A8 & 2.A.21.5 & 964 & SSF & 138.3 & Sodium-coupled monocarboxylate transporter 1 & $2 \times q 2 A$ & APC \\
\hline SLC5 & Q2M3M2 & SLC5A9 & 2.A.21.3 & 847.9 & SSF & 488.7 & Sodium/glucose cotransporter 4 & $2 \times q 2 A$ & APC \\
\hline SLC5 & AOPJK1 & SLC5A10 & 2.A.21.3 & 792 & SSF & 462.8 & Sodium/glucose cotransporter 5 & $2 \times q 2 \mathrm{~A}$ & APC \\
\hline SLC5 & Q8WWX8 & \begin{tabular}{|l|} 
SLC5A11 \\
\end{tabular} & 2.A.21.3 & 821 & SSF & 471.9 & Sodium/myo-inositol cotransporter 2 & $2 \times 92 \mathrm{~A}$ & APC \\
\hline SLC5 & Q1EHB4 & SLC5A12 & 2.A.21.5 & 988.3 & SSF & 153.3 & Sodium-coupled monocarboxylate transporter 2 & $2 \times q 2 A$ & APC \\
\hline SLC6 & P30531 & SLC6A1 & 2.A.22.3 & 937.7 & SNF & 775.7 & Sodium- and chloride-dependent GABA transporter 1 & 6vrlA & APC \\
\hline SLC6 & P23975 & SLC6A2 & 2.A.22.1 & 953.3 & SNF & 797 & Sodium-dependent noradrenaline transporter & 6vrlA & APC \\
\hline SLC6 & Q01959 & SLC6A3 & 2.A.22.1 & 936.2 & SNF & 781.2 & Sodium-dependent dopamine transporter & 6vrlA & APC \\
\hline SLC6 & P31645 & SLC6A4 & $2 . A .22 .1$ & 949.9 & SNF & 755.7 & Sodium-dependent serotonin transporter & 6vrlA & APC \\
\hline SLC6 & Q9Y345 & SLC6A5 & 2.A.22.2 & 1062.5 & SNF & 720.4 & Sodium- and chloride-dependent glycine transporter 2 & 6vrlA & APC \\
\hline SLC6 & P31641 & SLC6A6 & 2.A.22.3 & 989.4 & SNF & 798.9 & Sodium- and chloride-dependent taurine transporter & 6vrlA & APC \\
\hline SLC6 & Q99884 & SLC6A7 & 2.A.22.2 & 915.5 & SNF & 762.7 & Sodium-dependent proline transporter & 6vrlA & APC \\
\hline SLC6 & P48029 & SLC6A8 & 2.A.22.3 & 1022.1 & SNF & 802.9 & Sodium- and chloride-dependent creatine transporter 1 & 6vrlA & APC \\
\hline SLC6 & P48067 & SLC6A9 & 2.A.22.2 & 977.3 & SNF & 769.5 & Sodium- and chloride-dependent glycine transporter 1 & 6vrlA & APC \\
\hline SLC6 & P48066 & SLC6A11 & 2.A.22.3 & 1041.3 & SNF & 818 & Sodium- and chloride-dependent GABA transporter 3 & 6vrlA & APC \\
\hline SLC6 & P48065 & SLC6A12 & 2.A.22.3 & 1010.4 & SNF & 806.3 & Sodium- and chloride-dependent betaine transporter & 6vrlA & APC \\
\hline SLC6 & Q9NSD5 & SLC6A13 & 2.A.22.3 & 1033.6 & SNF & 815.4 & Sodium- and chloride-dependent GABA transporter 2 & 6vrlA & APC \\
\hline SLC6 & Q9UN76 & SLC6A14 & 2.A.22.2 & 917.2 & SNF & 647 & $\begin{array}{l}\text { Sodium- and chloride-dependent neutral and basic amino acid transporter } \\
\mathrm{B}(0+)\end{array}$ & 6vrlA & APC \\
\hline SLC6 & Q9H2J7 & SLC6A15 & 2.A.22.6 & 948.3 & SNF & 739.4 & Sodium-dependent neutral amino acid transporter $\mathrm{B}(0) \mathrm{AT} 2$ & 6vrlA & APC \\
\hline SLC6 & Q9GZN6 & SLC6A16 & 2.A.22.6 & 841.1 & SNF & 403.7 & $\begin{array}{l}\text { Orphan sodium- and chloride-dependent neurotransmitter transporter } \\
\text { NTT5 }\end{array}$ & 6vrlA & APC \\
\hline SLC6 & Q9H1V8 & SLC6A17 & 2.A.22.6 & 969.9 & SNF & 744.9 & Sodium-dependent neutral amino acid transporter SLC6A17 & 6vrlA & APC \\
\hline SLC6 & Q96N87 & SLC6A18 & 2.A.22.6 & 833.8 & SNF & 597.1 & Inactive sodium-dependent neutral amino acid transporter B(0)AT3 & 6vrlA & APC \\
\hline SLC6 & Q695T7 & \begin{tabular}{|l|} 
SLC6A19 \\
\end{tabular} & 2.A.22.6 & 887 & SNF & 593.3 & Sodium-dependent neutral amino acid transporter B(0)AT1 & $6 \mathrm{~m} 17 \mathrm{C}$ & APC \\
\hline SLC6 & Q9NP91 & SLC6A20 & 2.A.22.6 & 840.1 & SNF & 583.1 & Sodium- and chloride-dependent transporter XTRP3 & 6vrlA & APC \\
\hline SLC7 & P30825 & SLC7A1 & 2.A.3.3 & 704.6 & AA_permease_2 & 170.1 & High affinity cationic amino acid transporter 1 & $7 \mathrm{dsnB}$ & APC \\
\hline SLC7 & P52569 & SLC7A2 & 2.A.3.3 & 708.6 & AA_permease_2 & 172.3 & Cationic amino acid transporter 2 & $7 \mathrm{dsnB}$ & APC \\
\hline SLC7 & Q8WY07 & SLC7A3 & 2.A.3.3 & 679.3 & AA_permease_2 & 165 & Cationic amino acid transporter 3 & $7 \mathrm{dsnB}$ & APC \\
\hline SLC7 & 043246 & SLC7A4 & 2.A.3.3 & 608 & AA_permease_2 & 164.3 & Cationic amino acid transporter 4 & $7 \mathrm{dsnB}$ & APC \\
\hline SLC7 & Q01650 & SLC7A5 & 2.A.3.8 & 653.4 & AA_permease_2 & 213.9 & Large neutral amino acids transporter small subunit 1 & $7 \mathrm{dsnB}$ & APC \\
\hline SLC7 & Q8MH63 & \begin{tabular}{|l|} 
SLC7A5P1 \\
\end{tabular} & 2.A.3.8 & 194.1 & AA_permease_2 & 64 & Putative L-type amino acid transporter 1-like protein MLAS & 7dsnB & APC \\
\hline SLC7 & Q9GIP4 & \begin{tabular}{|l|l} 
SLC7A5P2 \\
\end{tabular} & 2.A.3.8 & 179.6 & AA_permease_2 & 56.3 & Putative L-type amino acid transporter 1-like protein IMAA & $7 \mathrm{dsnB}$ & APC \\
\hline SLC7 & Q92536 & SLC7A6 & 2.A.3.8 & 657.6 & AA_permease_2 & 220.4 & $\mathrm{Y}+\mathrm{L}$ amino acid transporter 2 & $7 \mathrm{dsnB}$ & APC \\
\hline SLC7 & Q9UM01 & SLC7A7 & 2.A.3.8 & 642.3 & AA_permease_2 & 203.6 & $\mathrm{Y}+\mathrm{L}$ amino acid transporter 1 & 7dsnB & APC \\
\hline SLC7 & Q9UHI5 & SLC7A8 & 2.A.3.8 & 662.4 & AA_permease_2 & 232.7 & Large neutral amino acids transporter small subunit 2 & $7 \mathrm{dsnB}$ & APC \\
\hline SLC7 & P82251 & SLC7A9 & $2 . A .3 .8$ & 599 & AA_permease_2 & 212 & $\mathrm{~b}(0,+)$-type amino acid transporter 1 & 7dslB & APC \\
\hline SLC7 & Q9NS82 & SLC7A10 & 2.A.3.8 & 636.8 & AA_permease_2 & 205.4 & Asc-type amino acid transporter 1 & $7 \mathrm{dsnB}$ & APC \\
\hline SLC7 & Q9UPY5 & SLC7A11 & 2.A.3.8 & 607 & AA_permease_2 & 197.1 & Cystine/glutamate transporter & $7 \mathrm{dsnB}$ & APC \\
\hline SLC7 & Q8TCU3 & \begin{tabular}{|l|} 
SLC7A13 \\
\end{tabular} & 2.A.3.8 & 456.3 & AA_permease_2 & 135.9 & Solute carrier family 7 member 13 & $7 \mathrm{dsnB}$ & APC \\
\hline SLC7 & Q8TBB6 & SLC7A14 & $2 . A .3 .3$ & 719.7 & AA_permease_2 & 152.8 & Probable cationic amino acid transporter & 7dsIB & APC \\
\hline SLC8 & P32418 & SLC8A1 & 2.A.19.3 & 1869.3 & $\mathrm{Na}$ _Ca_ex & 210.9 & Sodium/calcium exchanger 1 & 4k1cA & NCX \\
\hline SLC8 & Q9UPR5 & SLC8A2 & 2.A.19.3 & 1730.6 & $\mathrm{Na}{ }_{-} \mathrm{Ca} \_\mathrm{ex}$ & 192.2 & Sodium/calcium exchanger 2 & $4 \mathrm{kjrA}$ & NCX \\
\hline SLC8 & P57103 & SLC8A3 & $2 . A .19 .3$ & 1812.3 & $\mathrm{Na}$ Ca_ex & 199.4 & Sodium/calcium exchanger 3 & 5hyaA & $\mathrm{NCX}$ \\
\hline SLC9 & P19634 & SLC9A1 & 2.A.36.1 & 845.9 & Na_H_Exchanger & 296.7 & Sodium/hydrogen exchanger 1 & $7 \mathrm{~d} s \times \mathrm{A}$ & NhaA \\
\hline SLC9 & Q9UBY0 & SLC9A2 & 2.A.36.1 & 869.6 & $\mathrm{Na}$ _H_Exchanger & 311.3 & Sodium/hydrogen exchanger 2 & $7 \mathrm{~d} s \times \mathrm{A}$ & NhaA \\
\hline SLC9 & P48764 & SLC9A3 & 2.A.36.1 & 864.9 & $\mathrm{Na} \_\mathrm{H} \_$Exchanger & 287.6 & Sodium/hydrogen exchanger 3 & 7dsxA & NhaA \\
\hline SLC9 & Q6Al14 & SLC9A4 & 2.A.36.1 & 834.3 & $\mathrm{Na} \_\mathrm{H} \_$Exchanger & 299.6 & Sodium/hydrogen exchanger 4 & $7 d s \times A$ & NhaA \\
\hline
\end{tabular}




\begin{tabular}{|c|c|c|c|c|c|}
\hline SLC9 & Q14940 & SLC9A5 & 2.A.36.1 & 856.4 & $\mathrm{Na}{ }_{3} H_{E}$ Exchanger \\
\hline SLC9 & Q92581 & SLC9A6 & 2.A.36.1 & 639.1 & $\mathrm{Na} \mathrm{N}_{\mathrm{H}}$ Exchanger \\
\hline SLC9 & Q96T83 & SLC9A7 & 2.A.36.1 & 660 & $\mathrm{Na}{ }_{2} \mathrm{H}_{-}$Exchanger \\
\hline SLC9 & Q9Y2E8 & SLC9A8 & 2.A.36.1 & 577.5 & $\mathrm{Na}{ }_{\mathrm{H}}$ Exchanger \\
\hline SLC9 & Q8IVB4 & SLC9A9 & 2.A.36.1 & 654.3 & $\mathrm{Na}{ }_{H}{ }_{-}$Exchanger \\
\hline SLC9 & Q4ZJ14 & SLC9B1 & 2.A.36.2 & 936.7 & $\mathrm{Na}{ }_{-} \mathrm{H} \_$Exchanger \\
\hline SLC9 & A6NJY1 & SLC9B1P1 & 2.A.36.2 & 461.9 & $\mathrm{Na}{ }_{-}{ }_{-}$Exchanger \\
\hline SLC9 & Q86UD5 & SLC9B2 & 2.A.36.2 & 944.3 & $\mathrm{Na}$ _H_Exchanger \\
\hline SLC9 & Q4G0N8 & SLC9C1 & 2.A.36.7 & 885.5 & $\mathrm{Na}{ }_{1} \mathrm{H}_{-}$Exchanger \\
\hline SLC9 & Q5TAH2 & SLC9C2 & 2.A.36.7 & 788.2 & $\mathrm{Na}$ _H_Exchanger \\
\hline SLC10 & Q14973 & SLC10A1 & 2.A.28.1 & 442.8 & SBF \\
\hline SLC10 & Q12908 & SLC10A2 & 2.A.28.1 & 454.7 & SBF \\
\hline SLC10 & P09131 & SLC10A3 & 2.A.28.1 & 449.2 & SBF \\
\hline SLC10 & Q96EP9 & SLC10A4 & 2.A.28.1 & 494.5 & SBF \\
\hline SLC10 & Q5PT55 & SLC10A5 & 2.A.28.1 & 426.1 & SBF \\
\hline SLC10 & Q3KNW5 & SLC10A6 & 2.A.28.1 & 480.6 & SBF \\
\hline SLC10 & Q0GE19 & SLC10A7 & 2.A.28.3 & 329.6 & SBF_like \\
\hline SLC11 & P49279 & SLC11A1 & 2.A.55.2 & 648.3 & Nramp \\
\hline $\begin{array}{l}\text { SLC11 } \\
\end{array}$ & P49281 & SLC11A2 & 2.A.55.2 & 689.7 & Nramp \\
\hline SLC12 & Q13621 & SLC12A1 & 2.A.30 & 1379 & AA_permease \\
\hline SLC12 & P55011 & SLC12A2 & 2.A.30 & 1423.3 & SLC12 \\
\hline SLC12 & P55017 & SLC12A3 & 2.A.30 & 1259.8 & AA_permease \\
\hline SLC12 & Q9UP95 & SLC12A4 & 2.A.30 & 1311.7 & AA_permease \\
\hline SLC12 & Q9H2X9 & SLC12A5 & 2.A.30 & 1343.5 & AA_permease \\
\hline SLC12 & Q9UHW9 & SLC12A6 & 2.A.30 & 1316.9 & AA_permease \\
\hline SLC12 & Q9Y666 & SLC12A7 & 2.A.30 & 1318.3 & AA_permease \\
\hline $\begin{array}{l}\mathrm{SLC12} \\
\end{array}$ & A0AV02 & SLC12A8 & 2.A.30 & 722.4 & AA_permease \\
\hline SLC12 & Q9BXP2 & SLC12A9 & 2.A.30 & 884.4 & AA_permease \\
\hline SLC13 & Q9BZW2 & SLC13A1 & 2.A.47.1 & 746.2 & Na_sulph_symp \\
\hline SLC13 & Q13183 & SLC13A2 & 2.A.47.1 & 767.7 & Na_sulph_symp \\
\hline SLC13 & Q8WWT9 & SLC13A3 & 2.A.47.1 & 783.7 & Na_sulph_symp \\
\hline SLC13 & Q9UKG4 & SLC13A4 & 2.A.47.1 & 772.2 & Na_sulph_symp \\
\hline SLC13 & Q86YT5 & SLC13A5 & 2.A.47.1 & 772.4 & Na_sulph_symp \\
\hline SLC14 & Q13336 & SLC14A1 & 1.A.28.1 & 693.5 & UT \\
\hline SLC14 & Q15849 & SLC14A2 & 1.A.28.1 & 1405.6 & UT \\
\hline SLC15 & P46059 & SLC15A1 & 2.A.17.4 & 1012.4 & $\begin{array}{l}\text { PTR2 } \\
\end{array}$ \\
\hline SLC15 & Q16348 & SLC15A2 & 2.A.17.4 & 1017.2 & PTR2 \\
\hline SLC15 & Q8IY34 & SLC15A3 & 2.A.17.3 & 608.9 & PTR2 \\
\hline SLC15 & Q8N697 & SLC15A4 & 2.A.17.3 & 609.7 & PTR2 \\
\hline SLC15 & A6NIM6 & SLC15A5 & 2.A.17.3 & 526.8 & PTR2 \\
\hline SLC16 & P53985 & SLC16A1 & 2.A.1.13 & 482 & MFS_1 \\
\hline SLC16 & P36021 & SLC16A2 & 2.A.1.13 & 571.2 & MFS_1 \\
\hline SLC16 & 015427 & SLC16A3 & 2.A.1.13 & 494.7 & MFS_1 \\
\hline SLC16 & 015374 & SLC16A4 & 2.A.1.13 & 499.7 & MFS_1 \\
\hline SLC16 & 015375 & SLC16A5 & 2.A.1.13 & 493.1 & MFS_1 \\
\hline SLC16 & 015403 & SLC16A6 & 2.A.1.13 & 453.9 & MFS_1 \\
\hline SLC16 & 060669 & SLC16A7 & 2.A.1.13 & 504.2 & MFS_1 \\
\hline SLC16 & 095907 & SLC16A8 & 2.A.1.13 & 497.9 & MFS_1 \\
\hline SLC16 & Q7RTY1 & SLC16A9 & 2.A.1.13 & 484.2 & MFS_1 \\
\hline SLC16 & Q8TF71 & SLC16A10 & 2.A.1.13 & 561.5 & MFS_1 \\
\hline
\end{tabular}

291.9 Sodium/hydrogen exchanger 5 319.5 Sodium/hydrogen exchanger 6 304 Sodium/hydrogen exchanger 7 226.2 Sodium/hydrogen exchanger 8 291.1 Sodium/hydrogen exchanger 9 103.8 Sodium/hydrogen exchanger 9B1

61.9 Putative SLC9B1-like protein SLC9B1P1

104.8 Sodium/hydrogen exchanger 9B2 96.8 Sodium/hydrogen exchanger 10 72.5 Sodium/hydrogen exchanger 11 165.9 Sodium/bile acid cotransporter

159.4 Ileal sodium/bile acid cotransporter

149 P3 protein

117.8 Sodium/bile acid cotransporter 4

123.6 Sodium/bile acid cotransporter 5

148.7 Solute carrier family 10 member 6

265 Sodium/bile acid cotransporter 7

390.2 Natural resistance-associated macrophage protein 1

399.7 Natural resistance-associated macrophage protein 2

504 Solute carrier family 12 member 1 543.5 Solute carrier family 12 member 2

462.9 Solute carrier family 12 member 3

217.9 Solute carrier family 12 member 4

202.1 Solute carrier family 12 member 5

213 Solute carrier family 12 member 6

201.3 Solute carrier family 12 member 7

149.7 Solute carrier family 12 member 8

395.1 Solute carrier family 12 member 9

323.4 Solute carrier family 13 member 1

619.3 Solute carrier family 13 member 2

351 Solute carrier family 13 member 3

350.7 Solute carrier family 13 member 4

431.9 Solute carrier family 13 member 5

370.4 Urea transporter 1

712.9 Urea transporter 2

488.2 Solute carrier family 15 member 1

461.8 Solute carrier family 15 member 2

276.3 Solute carrier family 15 member 3

398.6 Solute carrier family 15 member 4

118.6 Solute carrier family 15 member 5

\begin{tabular}{r|l}
144.4 & Monocarboxylate transporter 1 \\
\hline 99.7 & Monocarboxylate transporter 8
\end{tabular}

105.1 Monocarboxylate transporter 4

124.5 Monocarboxylate transporter 5

122.2 Monocarboxylate transporter 6

122.1 Monocarboxylate transporter 7

141.5 Monocarboxylate transporter 2

96.9 Monocarboxylate transporter 3

116.6 Monocarboxylate transporter 9

117.1 Monocarboxylate transporter 10

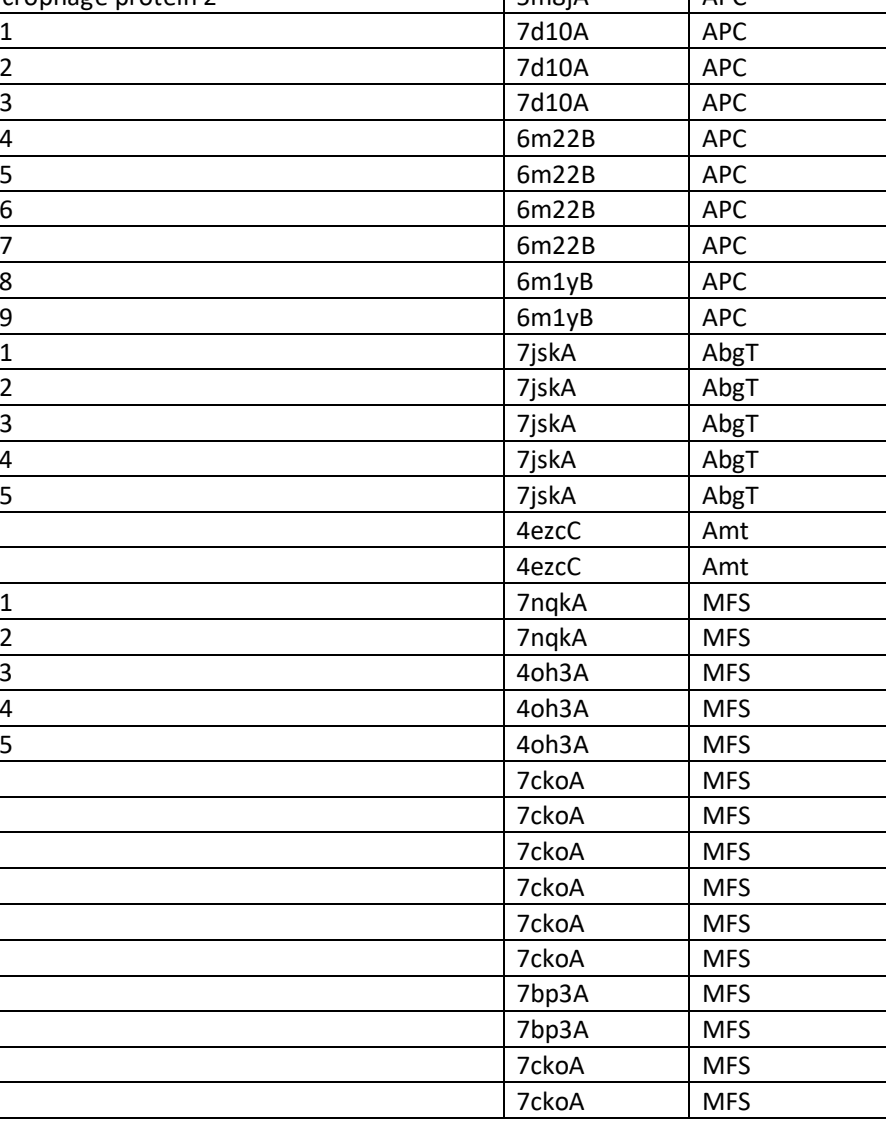




\begin{tabular}{|c|c|c|c|c|c|c|c|c|c|}
\hline SLC16 & Q8NCK7 & SLC16A11 & 2.A.1.13 & 398.9 & MFS_1 & 108.8 & Monocarboxylate transporter 11 & 7ckoA & MFS \\
\hline SLC16 & Q6ZSM3 & SLC16A12 & 2.A.1.13 & 489.8 & MFS_1 & 125.6 & Monocarboxylate transporter 12 & 7ckoA & MFS \\
\hline SLC16 & Q7RTYO & SLC16A13 & 2.A.1.13 & 397.3 & MFS_1 & 111.1 & Monocarboxylate transporter 13 & $7 \mathrm{bp} 3 \mathrm{~A}$ & MFS \\
\hline SLC16 & Q7RTX9 & SLC16A14 & 2.A.1.13 & 518.3 & MFS_1 & 166.9 & Monocarboxylate transporter 14 & 7ckoA & MFS \\
\hline SLC17 & Q14916 & SLC17A1 & 2.A.1.14 & 418.3 & MFS_1 & 164.1 & Sodium-dependent phosphate transport protein 1 & $6 \mathrm{v} 4 \mathrm{dA}$ & MFS \\
\hline SLC17 & 000624 & SLC17A2 & 2.A.1.14 & 407.5 & MFS_1 & 148.1 & Sodium-dependent phosphate transport protein 3 & $6 \mathrm{v} 4 \mathrm{dA}$ & MFS \\
\hline SLC17 & 000476 & SLC17A3 & 2.A.1.14 & 334.5 & MFS_1 & 119.5 & Sodium-dependent phosphate transport protein 4 & $6 \mathrm{v} 4 \mathrm{dA}$ & MFS \\
\hline SLC17 & Q9Y2C5 & SLC17A4 & 2.A.1.14 & 447.9 & MFS_1 & 184.4 & Probable small intestine urate exporter & $6 \mathrm{v} 4 \mathrm{dA}$ & MFS \\
\hline SLC17 & Q9NRA2 & SLC17A5 & 2.A.1.14 & 516.9 & MFS_1 & 210.7 & Sialin & $6 \mathrm{v} 4 \mathrm{dA}$ & MFS \\
\hline SLC17 & Q9P2U8 & SLC17A6 & 2.A.1.14 & 657.2 & MFS_1 & 169 & Vesicular glutamate transporter 2 & $6 \mathrm{v} 4 \mathrm{dA}$ & MFS \\
\hline SLC17 & Q9P2U7 & \begin{tabular}{|l} 
SLC17A7 \\
\end{tabular} & 2.A.1.14 & 649.6 & MFS_1 & 161.6 & Vesicular glutamate transporter 1 & $6 \mathrm{v} 4 \mathrm{dA}$ & MFS \\
\hline SLC17 & Q8NDX2 & SLC17A8 & 2.A.1.14 & 650.6 & MFS_1 & 158.1 & Vesicular glutamate transporter 3 & $6 \mathrm{v} 4 \mathrm{dA}$ & MFS \\
\hline SLC17 & Q9BYT1 & SLC17A9 & 2.A.1.14 & 316.9 & MFS_1 & 191.4 & Solute carrier family 17 member 9 & $6 \mathrm{e} 9 \mathrm{nA}$ & MFS \\
\hline SLC18 & P54219 & SLC18A1 & 2.A.1.2 & 323.7 & MFS_1 & 138.8 & Chromaffin granule amine transporter & $6 \mathrm{v} 4 \mathrm{dA}$ & MFS \\
\hline SLC18 & Q05940 & SLC18A2 & 2.A.1.2 & 331.7 & MFS_1 & 152.5 & Synaptic vesicular amine transporter & $7 \mathrm{mjsX}$ & MFS \\
\hline SLC18 & Q16572 & SLC18A3 & 2.A.1.2 & 303 & MFS_1 & 125.6 & Vesicular acetylcholine transporter & $7 \mathrm{mjsX}$ & MFS \\
\hline SLC18 & Q6NT16 & SLC18B1 & 2.A.1.2 & 201.4 & MFS_1 & 159.6 & MFS-type transporter SLC18B1 & $6 \mathrm{kklA}$ & MFS \\
\hline SLC19 & P41440 & \begin{tabular}{|l|} 
SLC19A1 \\
\end{tabular} & 2.A.48 & 736.2 & Folate_carrier & 564.9 & Folate transporter 1 & $7 \mathrm{bp} 3 \mathrm{~A}$ & MFS \\
\hline SLC19 & 060779 & SLC19A2 & 2.A.48 & 684.7 & Folate_carrier & 581.7 & Thiamine transporter 1 & $4 \mathrm{j} 05 \mathrm{~A}$ & MFS \\
\hline SLC19 & Q9BZV2 & SLC19A3 & 2.A.48 & 697.8 & Folate_carrier & 603.9 & Thiamine transporter 2 & $4 \mathrm{j} 05 \mathrm{~A}$ & MFS \\
\hline SLC20 & Q8WUM9 & SLC20A1 & 2.A.20.2 & 654.1 & $\mathrm{PHO} 4$ & 470.2 & Sodium-dependent phosphate transporter 1 & $6185 \mathrm{~B}$ & PiT \\
\hline SLC20 & Q08357 & SLC2OA2 & 2.A.20.2 & 639.7 & PHO4 & 464.7 & Sodium-dependent phosphate transporter 2 & $6185 \mathrm{~B}$ & PiT \\
\hline SLC21/SLCO & P46721 & SLCO1A2 & 2.A.60.1 & 799 & OATP & 561.9 & Solute carrier organic anion transporter family member $1 \mathrm{~A} 2$ & $7 \mathrm{bp} 3 \mathrm{~A}$ & MFS \\
\hline SLC21/SLCO & Q9Y6L6 & SLCO1B1 & 2.A.60.1 & 814.7 & OATP & 568.5 & Solute carrier organic anion transporter family member 1B1 & 7ckoA & MFS \\
\hline SLC21/SLCO & Q9NPD5 & SLCO1B3 & 2.A.60.1 & 838.5 & OATP & 572 & Solute carrier organic anion transporter family member 1B3 & 6e8jA & MFS \\
\hline SLC21/SLCO & G3VOH7 & SLCO1B7 & 2.A.60.1 & 755.9 & OATP & 522 & Putative solute carrier organic anion transporter family member 1B7 & 7ckoA & MFS \\
\hline SLC21/SLCO & Q9NYB5 & SLCO1C1 & 2.A.60.1 & 851.4 & OATP & 599.6 & Solute carrier organic anion transporter family member $1 \mathrm{C} 1$ & $7 \mathrm{mjs}$ & MFS \\
\hline SLC21/SLCO & Q92959 & SLCO2A1 & 2.A.60 & 737.8 & OATP & 588.9 & Solute carrier organic anion transporter family member 2A1 & $6 \mathrm{e} 8 \mathrm{jA}$ & MFS \\
\hline SLC21/SLCO & 094956 & SLCO2B1 & 2.A.60.1 & 757.5 & OATP & 649 & Solute carrier organic anion transporter family member 2B1 & 6lyyA & MFS \\
\hline SLC21/SLCO & Q9UIG8 & SLCO3A1 & 2.A.60.1 & 764.3 & OATP & 599.7 & Solute carrier organic anion transporter family member 3A1 & $7 \mathrm{mjsX}$ & MFS \\
\hline SLC21/SLCO & Q96BD0 & SLCO4A1 & 2.A.60.1 & 723.5 & OATP & 600.2 & Solute carrier organic anion transporter family member 4A1 & $7 \mathrm{mjsX}$ & MFS \\
\hline SLC21/SLCO & Q6ZQN7 & SLCO4C1 & 2.A.60 & 759.7 & OATP & 596.4 & Solute carrier organic anion transporter family member $4 \mathrm{C} 1$ & $7 \mathrm{mjsX}$ & MFS \\
\hline SLC21/SLCO & Q9H2Y9 & SLCO5A1 & 2.A.60 & 848 & OATP & 618.5 & Solute carrier organic anion transporter family member $5 \mathrm{~A} 1$ & $6 \mathrm{e} 8 \mathrm{jA}$ & MFS \\
\hline SLC21/SLCO & Q86UG4 & SLCO6A1 & 2.A.60 & 666.3 & OATP & 436.2 & Solute carrier organic anion transporter family member $6 \mathrm{~A} 1$ & 6vyhA & MFS \\
\hline SLC22 & 015245 & SLC22A1 & 2.A.1.19 & 606 & Sugar_tr & 122.2 & Solute carrier family 22 member 1 & 4zw9A & MFS \\
\hline SLC22 & 015244 & SLC22A2 & 2.A.1.19 & 623.7 & Sugar_tr & 130.3 & Solute carrier family 22 member 2 & 4zw9A & MFS \\
\hline SLC22 & 075751 & SLC22A3 & 2.A.1.19 & 617.6 & Sugar_tr & 92 & Solute carrier family 22 member 3 & $4 \mathrm{j} 05 \mathrm{~A}$ & MFS \\
\hline SLC22 & Q9H015 & SLC22A4 & 2.A.1.19 & 562.2 & MFS_1 & 89.1 & Solute carrier family 22 member 4 & 5eqhA & MFS \\
\hline SLC22 & 076082 & SLC22A5 & 2.A.1.19 & 593.9 & Sugar_tr & 92.9 & Solute carrier family 22 member 5 & 4zw9A & MFS \\
\hline SLC22 & Q4U2R8 & SLC22A6 & 2.A.1.19 & 655.1 & Sugar_tr & 114.1 & Solute carrier family 22 member 6 & 7ckoA & MFS \\
\hline SLC22 & Q9Y694 & \begin{tabular}{|l} 
SLC22A7 \\
\end{tabular} & 2.A.1.19 & 572.1 & MFS_1 & 108.9 & Solute carrier family 22 member 7 & 4zW9A & MFS \\
\hline SLC22 & Q8TCC7 & SLC22A8 & 2.A.1.19 & 623.2 & Sugar_tr & 121.2 & Solute carrier family 22 member 8 & $4 \mathrm{j} 05 \mathrm{~A}$ & MFS \\
\hline SLC22 & Q8IVM8 & SLC22A9 & 2.A.1.19 & 544.7 & MFS_1 & 102.3 & Solute carrier family 22 member 9 & 5eqhA & MFS \\
\hline SLC22 & Q63ZE4 & SLC22A10 & 2.A.1.19 & 570.8 & Sugar_tr & 89.6 & Solute carrier family 22 member 10 & 5eqhA & MFS \\
\hline SLC22 & Q9NSA0 & SLC22A11 & 2.A.1.19 & 568.8 & Sugar_tr & 95 & Solute carrier family 22 member 11 & 5eqhA & MFS \\
\hline SLC22 & Q96S37 & SLC22A12 & 2.A.1.19 & 566.5 & MFS_1 & 81.3 & Solute carrier family 22 member 12 & 5eqhA & MFS \\
\hline SLC22 & Q9Y226 & SLC22A13 & 2.A.1.19 & 582.8 & Sugar_tr & 119.8 & Solute carrier family 22 member 13 & $4 \mathrm{j05A}$ & MFS \\
\hline SLC22 & Q9Y267 & SLC22A14 & 2.A.1.19 & 502.7 & Sugar_tr & 75.3 & Solute carrier family 22 member 14 & 5eqhA & MFS \\
\hline SLC22 & Q8IZD6 & \begin{tabular}{|l|} 
SLC22A15 \\
\end{tabular} & 2.A.1.19 & 525.6 & MFS_1 & 94.4 & Solute carrier family 22 member 15 & 4zw9A & MFS \\
\hline SLC22 & Q86VW1 & SLC22A16 & 2.A.1.19 & 558.9 & Sugar_tr & 93.8 & Solute carrier family 22 member 16 & 5eqhA & MFS \\
\hline
\end{tabular}




\begin{tabular}{|c|c|c|c|c|c|c|c|c|c|}
\hline SLC22 & Q8WUG5 & SLC22A17 & 2.A.1.19 & 431.8 & Sugar_tr & 65.2 & Solute carrier family 22 member 17 & 5eqhA & MFS \\
\hline SLC22 & A6NK97 & SLC22A2OP & 2.A.1.19 & 603.8 & Sugar_tr & 83.4 & Solute carrier family 22 member 20 & 5eqhA & MFS \\
\hline SLC22 & A1A5C7 & SLC22A23 & \begin{tabular}{|l|} 
2.A.1.19 \\
\end{tabular} & 588.3 & Sugar_tr & 85.7 & Solute carrier family 22 member 23 & 5eqhA & MFS \\
\hline SLC22 & Q8N4F4 & SLC22A24 & 2.A.1.19 & 281.5 & MFS_1 & 54.4 & Solute carrier family 22 member 24 & 4 IdsB & MFS \\
\hline SLC22 & Q6T423 & SLC22A25 & 2.A.1.19 & 538.1 & MFS_1 & 72.6 & Solute carrier family 22 member 25 & 5eqhA & MFS \\
\hline SLC22 & A6NKX4 & SLC22A31 & 2.A.1.19 & 422 & Sugar_tr & 55.4 & Putative solute carrier family 22 member 31 & 5eqhA & MFS \\
\hline SLC23 & Q9UHI7 & SLC23A1 & 2.A.40.6 & 978.9 & Xan_ur_permease & 306.1 & Solute carrier family 23 member 1 & $5 \mathrm{i} 6 \mathrm{cA}$ & NAT \\
\hline SLC23 & Q9UGH3 & SLC23A2 & 2.A.40.6 & 955.9 & Xan_ur_permease & 301.4 & Solute carrier family 23 member 2 & 5i6cA & NAT \\
\hline SLC23 & Q6PIS1 & SLC23A3 & 2.A.40.6 & 771.3 & Xan_ur_permease & 292.6 & Solute carrier family 23 member 3 & 5i6cA & NAT \\
\hline SLC24 & Q6J4K2 & SLC8B1 & 2.A.19.4 & 380.5 & $\mathrm{Na}$ _Ca_ex & 161.7 & Mitochondrial sodium/calcium exchanger protein & $4 \mathrm{kjrA}$ & NCX \\
\hline SLC24 & 060721 & SLC24A1 & 2.A.19.4 & 793 & $\mathrm{Na}$ _Ca_ex & 194 & Sodium/potassium/calcium exchanger 1 & $4 \mathrm{kjrA}$ & NCX \\
\hline SLC24 & Q9U140 & SLC24A2 & 2.A.19.4 & 717.2 & $\mathrm{Na}{ }_{2} \mathrm{Ca}_{-} \mathrm{ex}$ & 209.9 & Sodium/potassium/calcium exchanger 2 & $4 \mathrm{kjrA}$ & NCX \\
\hline SLC24 & Q9HC58 & SLC24A3 & 2.A.19.4 & 681.1 & $\mathrm{Na}$ CCa_ex & 192.7 & Sodium/potassium/calcium exchanger 3 & 5hyaA & NCX \\
\hline SLC24 & Q8NFF2 & SLC24A4 & 2.A.19.4 & 647.8 & $\mathrm{Na}$ _Ca_ex & 193.8 & Sodium/potassium/calcium exchanger 4 & $4 \mathrm{kjrA}$ & NCX \\
\hline SLC24 & Q71RS6 & SLC24A5 & 2.A.19.4 & 517.4 & $\mathrm{Na}$ _Ca_ex & 170.7 & Sodium/potassium/calcium exchanger 5 & 5hyaA & NCX \\
\hline SLC25 & P53007 & SLC25A1 & 2.A.29.7 & 610.3 & Mito_carr & 207.5 & Tricarboxylate transport protein, mitochondrial & $4 \mathrm{c} 9 \mathrm{hB}$ & MCF \\
\hline SLC25 & Q9BXI2 & SLC25A2 & 2.A.29.19 & 691.4 & Mito_carr & 198.1 & Mitochondrial ornithine transporter 2 & $4 \mathrm{c} 9 \mathrm{hB}$ & MCF \\
\hline SLC25 & Q00325 & SLC25A3 & 2.A.29.4 & 656.8 & Mito_carr & 163.2 & Phosphate carrier protein, mitochondrial & $4 \mathrm{c} 9 \mathrm{hB}$ & MCF \\
\hline SLC25 & P12235 & SLC25A4 & 2.A.29.1 & 522.3 & Mito_carr & 229.2 & ADP/ATP translocase 1 & 10kcA & MCF \\
\hline SLC25 & P05141 & SLC25A5 & 2.A.29.1 & 520.1 & Mito_carr & 225.1 & ADP/ATP translocase 2 & 10kcA & MCF \\
\hline SLC25 & P12236 & SLC25A6 & 2.A.29.1 & 524.1 & Mito_carr & 228.1 & ADP/ATP translocase 3 & 10kcA & MCF \\
\hline SLC25 & P25874 & SLC25A7 (UCP1) & 2.A.29.3 & 544.7 & Mito_carr & 203.3 & Mitochondrial brown fat uncoupling protein 1 & $4 \mathrm{c} 9 \mathrm{hB}$ & MCF \\
\hline SLC25 & P55851 & SLC25A8 (UCP2) & 2.A.29.3 & 546.3 & Mito carr & 223.6 & Mitochondrial uncoupling protein 2 & 21ckA & MCF \\
\hline SLC25 & P55916 & SLC25A9 (UCP3) & 2.A.29.3 & 560.8 & Mito_carr & 217.2 & Mitochondrial uncoupling protein 3 & 2IckA & MCF \\
\hline SLC25 & Q9UBX3 & SLC25A10 & 2.A.29.2 & 376.2 & Mito_carr & 186.7 & Mitochondrial dicarboxylate carrier & $4 \mathrm{c} 9 \mathrm{hB}$ & $\mathrm{MCF}$ \\
\hline SLC25 & Q02978 & SLC25A11 & 2.A.29.2 & 434.9 & Mito_carr & 199.7 & Mitochondrial 2-oxoglutarate/malate carrier protein & $4 \mathrm{c} 9 \mathrm{hB}$ & MCF \\
\hline SLC25 & 075746 & SLC25A12 & 2.A.29.14 & 453.5 & Mito_carr & 237.9 & Calcium-binding mitochondrial carrier protein Aralar1 & $4 \mathrm{c} 9 \mathrm{hB}$ & MCF \\
\hline SLC25 & Q9UJS0 & SLC25A13 & 2.A.29.14 & 455.9 & Mito_carr & 239.1 & Calcium-binding mitochondrial carrier protein Aralar2 & $4 \mathrm{c} 9 \mathrm{hB}$ & MCF \\
\hline SLC25 & 095258 & SLC25A14 & 2.A.29.24 & 595.3 & Mito_carr & 220.5 & Brain mitochondrial carrier protein 1 & $4 \mathrm{c} 9 \mathrm{hB}$ & MCF \\
\hline SLC25 & Q9Y619 & SLC25A15 & 2.A.29.19 & 694.4 & Mito_carr & 204 & Mitochondrial ornithine transporter 1 & $4 \mathrm{c} 9 \mathrm{hB}$ & MCF \\
\hline SLC25 & P16260 & SLC25A16 & 2.A.29.12 & 481.6 & Mito_carr & 237.7 & Graves disease carrier protein & $4 \mathrm{c} 9 \mathrm{hB}$ & MCF \\
\hline SLC25 & 043808 & SLC25A17 & 2.A.29.20 & 504.1 & Mito_carr & 186.9 & Peroxisomal membrane protein PMP34 & $4 \mathrm{c} 9 \mathrm{hB}$ & MCF \\
\hline SLC25 & Q9H1K4 & SLC25A18 & 2.A.29.14 & 363.6 & Mito_carr & 205.8 & Mitochondrial glutamate carrier 2 & $4 \mathrm{c} 9 \mathrm{hB}$ & MCF \\
\hline SLC25 & Q9HC21 & SLC25A19 & \begin{tabular}{|l|} 
2.A.29.16 \\
\end{tabular} & 557.8 & Mito carr & 222.3 & Mitochondrial thiamine pyrophosphate carrier & $4 \mathrm{c} 9 \mathrm{hB}$ & MCF \\
\hline SLC25 & 043772 & SLC25A20 & 2.A.29.8 & 394 & Mito_carr & 235.5 & Mitochondrial carnitine/acylcarnitine carrier protein & $4 \mathrm{c} 9 \mathrm{hB}$ & MCF \\
\hline SLC25 & Q9BQT8 & SLC25A21 & 2.A.29.2 & 334.9 & Mito_carr & 205.2 & Mitochondrial 2-oxodicarboxylate carrier & $4 \mathrm{c} 9 \mathrm{hB}$ & MCF \\
\hline SLC25 & Q9H936 & SLC25A22 & 2.A.29.14 & 367.9 & Mito_carr & 210.7 & Mitochondrial glutamate carrier 1 & $4 \mathrm{c} 9 \mathrm{hB}$ & MCF \\
\hline SLC25 & Q9BV35 & SLC25A23 & 2.A.29.23 & 553.1 & Mito_carr & 238.5 & Calcium-binding mitochondrial carrier protein SCaMC-3 & $4 \mathrm{c} 9 \mathrm{hB}$ & MCF \\
\hline SLC25 & Q6NUK1 & SLC25A24 & 2.A.29.23 & 551.2 & Mito_carr & 248.9 & Calcium-binding mitochondrial carrier protein SCaMC-1 & $4 \mathrm{c} 9 \mathrm{hB}$ & MCF \\
\hline SLC25 & Q6KCM7 & SLC25A25 & 2.A.29.23 & 540.6 & Mito_carr & 241.1 & Calcium-binding mitochondrial carrier protein SCaMC-2 & $4 \mathrm{c} 9 \mathrm{hB}$ & MCF \\
\hline SLC25 & Q7OHW3 & SLC25A26 & 2.A.29.18 & 384.6 & Mito_carr & 166 & S-adenosylmethionine mitochondrial carrier protein & $4 \mathrm{c} 9 \mathrm{hB}$ & MCF \\
\hline SLC25 & 095847 & SLC25A27 & 2.A.29.24 & 542 & Mito_carr & 217.3 & Mitochondrial uncoupling protein 4 & $4 \mathrm{c} 9 \mathrm{hB}$ & MCF \\
\hline SLC25 & Q96A46 & SLC25A28 & 2.A.29.5 & 595.5 & Mito_carr & 207 & Mitoferrin-2 & $4 \mathrm{c} 9 \mathrm{hB}$ & MCF \\
\hline SLC25 & Q8N8R3 & SLC25A29 & 2.A.29.8 & 387.5 & Mito_carr & 218.5 & Mitochondrial basic amino acids transporter & $4 \mathrm{c} 9 \mathrm{hB}$ & MCF \\
\hline SLC25 & Q5SVS4 & SLC25A30 & 2.A.29.24 & 596.1 & Mito_carr & 228 & Kidney mitochondrial carrier protein 1 & $4 \mathrm{c} 9 \mathrm{hB}$ & MCF \\
\hline SLC25 & Q9H0C2 & SLC25A31 & 2.A.29.1 & 509.1 & Mito_carr & 239.2 & ADP/ATP translocase 4 & 1okcA & MCF \\
\hline SLC25 & Q9H2D1 & SLC25A32 & 2.A.29.10 & 375.3 & Mito_carr & 232.2 & Mitochondrial folate transporter/carrier & $4 \mathrm{c} 9 \mathrm{hB}$ & MCF \\
\hline SLC25 & Q9BSK2 & SLC25A33 & 2.A.29.10 & 378.3 & Mito_carr & 217 & Solute carrier family 25 member 33 & $4 \mathrm{c} 9 \mathrm{hB}$ & MCF \\
\hline SLC25 & Q6PIV7 & SLC25A34 & 2.A.29.15 & 550.4 & Mito_carr & 165.9 & Solute carrier family 25 member 34 & $4 \mathrm{c} 9 \mathrm{hB}$ & MCF \\
\hline SLC25 & Q3KQZ1 & SLC25A35 & 2.A.29.15 & 555.6 & Mito_carr & 163.2 & Solute carrier family 25 member 35 & $4 \mathrm{c} 9 \mathrm{hB}$ & MCF \\
\hline
\end{tabular}




\begin{tabular}{|c|c|c|c|c|c|c|c|c|c|}
\hline SLC25 & Q96CQ1 & SLC25A36 & 2.A.29.10 & 382.7 & Mito carr & 227.4 & Solute carrier family 25 member 36 & $4 \mathrm{c} 9 \mathrm{hB}$ & MCF \\
\hline SLC25 & Q9NYZ2 & SLC25A37 & 2.A.29.5 & 577.2 & Mito_carr & 212.4 & Mitoferrin-1 & $4 \mathrm{c} 9 \mathrm{hB}$ & MCF \\
\hline SLC25 & Q96DW6 & SLC25A38 & 2.A.29.5 & 394.9 & Mito_carr & 197.9 & Mitochondrial glycine transporter & $4 \mathrm{c} 9 \mathrm{hB}$ & MCF \\
\hline SLC25 & Q9BZJ4 & SLC25A39 & 2.A.29.14 & 361.2 & Mito_carr & 202 & Solute carrier family 25 member 39 & $4 \mathrm{c} 9 \mathrm{hB}$ & MCF \\
\hline SLC25 & Q8TBP6 & SLC25A40 & 2.A.29.14 & 361.8 & Mito_carr & 210 & Solute carrier family 25 member 40 & $4 \mathrm{c} 9 \mathrm{hB}$ & MCF \\
\hline SLC25 & Q8N5S1 & SLC25A41 & 2.A.29.23 & 440 & Mito_carr & 212.9 & Solute carrier family 25 member 41 & $4 \mathrm{c} 9 \mathrm{hB}$ & MCF \\
\hline SLC25 & Q86VD7 & SLC25A42 & 2.A.29.12 & 448 & Mito_carr & 239.9 & Mitochondrial coenzyme A transporter SLC25A42 & $4 \mathrm{c} 9 \mathrm{hB}$ & MCF \\
\hline SLC25 & Q8WUT9 & SLC25A43 & 2.A.29.23 & 368.6 & Mito_carr & 203.9 & Solute carrier family 25 member 43 & $4 \mathrm{c} 9 \mathrm{hB}$ & MCF \\
\hline SLC25 & Q96H78 & SLC25A44 & 2.A.29.14 & 313.6 & Mito_carr & 170.6 & Solute carrier family 25 member 44 & $4 \mathrm{c} 9 \mathrm{hB}$ & MCF \\
\hline SLC25 & Q8N413 & SLC25A45 & 2.A.29.8 & 366.8 & Mito_carr & 215.4 & Solute carrier family 25 member 45 & $4 \mathrm{c} 9 \mathrm{hB}$ & MCF \\
\hline SLC25 & Q96AG3 & SLC25A46 & 2.A.29.30 & 1010.6 & Mito_carr & 65.4 & Solute carrier family 25 member 46 & $4 \mathrm{c} 9 \mathrm{hB}$ & MCF \\
\hline SLC25 & Q6Q0C1 & SLC25A47 & 2.A.29.8 & 382.2 & Mito_carr & 200.5 & Solute carrier family 25 member 47 & $4 \mathrm{c} 9 \mathrm{hB}$ & MCF \\
\hline SLC25 & Q6ZT89 & SLC25A48 & 2.A.29.8 & 374.4 & Mito_carr & 202.2 & Solute carrier family 25 member 48 & $4 \mathrm{c} 9 \mathrm{hB}$ & MCF \\
\hline SLC25 & Q9NZI7 & SLC25A49 (MTCH1) & 2.A.29.25 & 845.6 & Mito_carr & 49.7 & Mitochondrial carrier homolog 1 & $4 \mathrm{c} 9 \mathrm{hB}$ & $\mathrm{MCF}$ \\
\hline SLC25 & Q9Y6C9 & SLC25A50 (MTCH2) & 2.A.29.25 & 584.8 & Mito_carr & 59.7 & Mitochondrial carrier homolog 2 & $4 \mathrm{c} 9 \mathrm{hB}$ & MCF \\
\hline SLC25 & Q9H1U9 & SLC25A51 & 2.A.29.2 & 319.3 & Mito_carr & 113.3 & Solute carrier family 25 member 51 & $4 \mathrm{c} 9 \mathrm{hB}$ & MCF \\
\hline SLC25 & Q3SY17 & SLC25A52 & 2.A.29.2 & 318.7 & Mito_carr & 116.2 & Solute carrier family 25 member 52 & $4 \mathrm{c} 9 \mathrm{hB}$ & MCF \\
\hline SLC25 & Q5H9E4 & SLC25A53 & 2.A.29.2 & 127.5 & Mito_carr & 85 & Solute carrier family 25 member 53 & $4 \mathrm{c} 9 \mathrm{hB}$ & MCF \\
\hline SLC26 & Q9H2B4 & SLC26A1 & 2.A.53.2 & 849.4 & Sulfate_transp & 424.8 & Sulfate anion transporter 1 & 7ch1B & NAT \\
\hline SLC26 & P50443 & SLC26A2 & 2.A.53.2 & 924.8 & Sulfate_transp & 445.1 & Sulfate transporter & 7ch1B & NAT \\
\hline SLC26 & P40879 & SLC26A3 & 2.A.53.2 & 998.1 & Sulfate_transp & 391.1 & Chloride anion exchanger & 7ch1B & NAT \\
\hline SLC26 & 043511 & SLC26A4 & 2.A.53.2 & 1007.5 & Sulfate_transp & 353.3 & Pendrin & 7ch1B & NAT \\
\hline SLC26 & P58743 & SLC26A5 & 2.A.53.2 & 990.7 & Sulfate_transp & 358.9 & Prestin & $7 \mathrm{ch} 1 \mathrm{~B}$ & NAT \\
\hline SLC26 & Q9BXS9 & SLC26A6 & 2.A.53.2 & 1000.1 & Sulfate_transp & 369.7 & Solute carrier family 26 member 6 & 7ch1B & NAT \\
\hline SLC26 & Q8TE54 & SLC26A7 & 2.A.53.2 & 754.9 & Sulfate_transp & 312 & Anion exchange transporter & 7ch1B & NAT \\
\hline SLC26 & Q96RN1 & SLC26A8 & 2.A.53.2 & 1058.5 & Sulfate_transp & 247.3 & Testis anion transporter 1 & 7ch1B & NAT \\
\hline SLC26 & Q7LBE3 & SLC26A9 & $2 . A .53 .2$ & 967.6 & Sulfate_transp & 312 & Solute carrier family 26 member 9 & 7ch1B & NAT \\
\hline SLC26 & Q8NG04 & SLC26A10 & 2.A.53.2 & 604.8 & Sulfate_transp & 302.2 & Solute carrier family 26 member 10 & $7 \operatorname{ch} 1 \mathrm{~B}$ & NAT \\
\hline SLC26 & Q86WA9 & SLC26A11 & 2.A.53.1 & 650.9 & Sulfate_transp & 318.8 & Sodium-independent sulfate anion transporter & 7ch1B & NAT \\
\hline SLC28 & 000337 & SLC28A1 & 2.A.41.2 & 1016.5 & Gate & 28.9 & Sodium/nucleoside cotransporter 1 & $6 \mathrm{kswA}$ & CNT \\
\hline SLC28 & 043868 & SLC28A2 & 2.A.41.2 & 1020.1 & Gate & 35.1 & Sodium/nucleoside cotransporter 2 & $6 \mathrm{kswA}$ & CNT \\
\hline SLC28 & Q9HAS3 & SLC28A3 & 2.A.41.2 & 1039.5 & Gate & 33.3 & Solute carrier family 28 member 3 & $6 \mathrm{kswA}$ & CNT \\
\hline SLC29 & Q99808 & SLC29A1 & 2.A.57.1 & 550.2 & Nucleoside tran & 439.6 & Equilibrative nucleoside transporter 1 & 6ob7A & MFS \\
\hline SLC29 & Q14542 & SLC29A2 & 2.A.57.1 & 551.3 & Nucleoside_tran & 420.7 & Equilibrative nucleoside transporter 2 & 6ob7A & MFS \\
\hline SLC29 & Q9BZD2 & SLC29A3 & 2.A.57.1 & 462.4 & Nucleoside_tran & 214.4 & Equilibrative nucleoside transporter 3 & $60 b 7 \mathrm{~A}$ & MFS \\
\hline SLC29 & Q7RTT9 & SLC29A4 & 2.A.57.1 & 551.5 & Nucleoside_tran & 160.3 & Equilibrative nucleoside transporter 4 & $60 b 7 \mathrm{~A}$ & MFS \\
\hline SLC30 & Q9Y6M5 & SLC30A1 & 2.A.4.2 & 603.8 & Cation_efflux & 155.5 & Zinc transporter 1 & $6 x p d A$ & CDF \\
\hline SLC30 & Q9BRI3 & SLC30A2 & 2.A.4.3 & 421.6 & Cation_efflux & 84.4 & Zinc transporter 2 & 6xpeA & CDF \\
\hline SLC30 & Q99726 & SLC30A3 & 2.A.4.3 & 497.7 & Cation_efflux & 153.7 & Zinc transporter 3 & $6 x p d A$ & CDF \\
\hline SLC30 & 014863 & SLC30A4 & 2.A.4.3 & 570.6 & Cation_efflux & 185.4 & Zinc transporter 4 & 6xpeA & CDF \\
\hline SLC30 & $\begin{array}{l}\text { Q8TAD4 } \\
\end{array}$ & SLC30A5 & 2.A.4.4 & 522.6 & Cation_efflux & 163.7 & Zinc transporter 5 & $6 x p d A$ & CDF \\
\hline SLC30 & \begin{tabular}{|l|} 
Q6NXT4 \\
\end{tabular} & SLC30A6 & \begin{tabular}{|l|} 
2.A.4.4 \\
\end{tabular} & 409.1 & Cation_efflux & 113.1 & Zinc transporter 6 & $6 x p d A$ & CDF \\
\hline SLC30 & Q8NEWO & SLC30A7 & 2.A.4.4 & 437.6 & Cation_efflux & 151 & Zinc transporter 7 & $6 x p d A$ & CDF \\
\hline SLC30 & Q8IWU4 & SLC30A8 & 2.A.4.3 & 493.3 & Cation_efflux & 148.1 & Zinc transporter 8 & $6 x p d A$ & CDF \\
\hline SLC30 & Q6PML9 & SLC30A9 & 2.A.4.6 & 1373.1 & Cation_efflux & 107.2 & Zinc transporter 9 & $3 \mathrm{j} 1 \mathrm{zQ}$ & CDF \\
\hline SLC30 & \begin{tabular}{|l|} 
Q6XR72 \\
\end{tabular} & SLC30A10 & 2.A.4.2 & 523.5 & Cation_efflux & 152.8 & Zinc transporter 10 & $6 x p d A$ & CDF \\
\hline SLC31 & 015431 & SLC31A1 & 1.A.56.1 & 173 & Ctr & 109.3 & High affinity copper uptake protein 1 & $6 \mathrm{~m} 97 \mathrm{~A}$ & Ctr \\
\hline SLC31 & 015432 & SLC31A2 & 1.A.56.1 & 119.1 & Ctr & 104.2 & Probable low affinity copper uptake protein 2 & $6 \mathrm{~m} 97 \mathrm{~A}$ & Ctr \\
\hline SLC32 & Q9H598 & SLC32A1 & 2.A.18.5 & 715.7 & Aa_trans & 331.5 & Vesicular inhibitory amino acid transporter & $7 \mathrm{kgvB}$ & APC \\
\hline SLC33 & 000400 & SLC33A1 & 2.A.1.25 & 554.7 & Acatn & 411.7 & Acetyl-coenzyme A transporter 1 & $7 \mathrm{mjs} X$ & MFS \\
\hline
\end{tabular}




\begin{tabular}{|c|c|c|c|c|c|c|c|c|c|}
\hline SLC34 & Q06495 & SLC34A1 & 2.A.58.1 & 703 & $\mathrm{Na}$ Pi cotrans & 138.8 & Sodium-dependent phosphate transport protein $2 \mathrm{~A}$ & & \\
\hline SLC34 & 095436 & SLC34A2 & 2.A.58.1 & 726.3 & Na_Pi_cotrans & 129.3 & Sodium-dependent phosphate transport protein 2B & & \\
\hline SLC34 & Q8N130 & SLC34A3 & $2 . A .58 .1$ & 639.8 & Na_Pi_cotrans & 127.5 & Sodium-dependent phosphate transport protein $2 \mathrm{C}$ & & \\
\hline SLC35 & P78382 & SLC35A1 & 2.A.7.12 & 412.1 & Nuc_sug_transp & 418.5 & CMP-sialic acid transporter & $6 x b o A$ & NST \\
\hline SLC35 & P78381 & SLC35A2 & 2.A.7.12 & 469.6 & Nuc_sug_transp & 446.6 & UDP-galactose translocator & 6ukjA & NST \\
\hline SLC35 & Q9Y2D2 & SLC35A3 & 2.A.7.12 & 437.6 & Nuc_sug_transp & 457.2 & UDP-N-acetylglucosamine transporter & $6 x b o A$ & NST \\
\hline SLC35 & Q96G79 & SLC35A4 & 2.A.7.12 & 293.1 & Nuc_sug_transp & 103.2 & Probable UDP-sugar transporter protein SLC35A4 & $6 \times b \circ A^{2}$ & NST \\
\hline SLC35 & Q9BS91 & SLC35A5 & 2.A.7.12 & 432.2 & Nuc_sug_transp & 176.1 & Probable UDP-sugar transporter protein SLC35A5 & $6 x b o A$ & NST \\
\hline SLC35 & P78383 & SLC35B1 & 2.A.7.11 & 398.2 & UAA & 189.4 & Solute carrier family 35 member B1 & 5ogeD & NST \\
\hline SLC35 & Q8TB61 & SLC35B2 & 2.A.7.11 & 487.8 & UAA & 252.1 & Adenosine 3'-phospho 5'-phosphosulfate transporter 1 & 5ogeD & NST \\
\hline SLC35 & Q9H1N7 & SLC35B3 & 2.A.7.11 & 399.1 & UAA & 313.7 & Adenosine 3'-phospho 5'-phosphosulfate transporter 2 & 6ukjA & NST \\
\hline SLC35 & Q969S0 & SLC35B4 & 2.A.7.10 & 518.6 & UAA & 390.3 & UDP-xylose and UDP-N-acetylglucosamine transporter & 5ogeG & NST \\
\hline SLC35 & Q96A29 & SLC35C1 & 2.A.7.16 & 633.9 & TPT & 75.3 & GDP-fucose transporter 1 & 5ogeD & NST \\
\hline SLC35 & Q9NQQ7 & SLC35C2 & 2.A.7.9 & 259.2 & TPT & 92 & Solute carrier family 35 member $\mathrm{C} 2$ & $5 y 78 \mathrm{~A}$ & NST \\
\hline SLC35 & Q9NTN3 & SLC35D1 & 2.A.7.15 & 530.3 & TPT & 58.6 & UDP-glucuronic acid/UDP-N-acetylgalactosamine transporter & 5ogeD & NST \\
\hline SLC35 & Q76EJ3 & SLC35D2 & 2.A.7.15 & 500.7 & TPT & 73.8 & UDP-N-acetylglucosamine/UDP-glucose/GDP-mannose transporter & 5ogeD & NST \\
\hline SLC35 & Q5M8T2 & SLC35D3 & 2.A.7.15 & 507.2 & EamA & 27.9 & Solute carrier family 35 member D3 & 6ukjA & NST \\
\hline SLC35 & Q96K37 & SLC35E1 & $2 . A .7 .9$ & 374.6 & TPT & 310.1 & Solute carrier family 35 member E1 & 6ukjA & NST \\
\hline SLC35 & POCK97 & SLC35E2A & 2.A.7.9 & 104.4 & TPT & 107.5 & Solute carrier family 35 member E2A & 6ukjA & NST \\
\hline SLC35 & P0CK96 & SLC35E2B & 2.A.7.9 & 297 & TPT & 312.3 & Solute carrier family 35 member E2B & 6ukjA & NST \\
\hline SLC35 & Q7Z769 & SLC35E3 & 2.A.7.9 & 234.5 & TPT & 72.1 & Solute carrier family 35 member E3 & 5ogeD & NST \\
\hline SLC35 & Q6ICL7 & SLC35E4 & 2.A.7.9 & 233.7 & TPT & 82.1 & Solute carrier family 35 member E4 & 5ogeD & NST \\
\hline SLC35 & Q5T1Q4 & SLC35F1 & 2.A.7.24 & 354.6 & SLC35F & 495.8 & Solute carrier family 35 member F1 & 6ukjA & NST \\
\hline SLC35 & Q8IXU6 & SLC35F2 & 2.A.7.24 & 344.1 & SLC35F & 492.9 & Solute carrier family 35 member $\mathrm{F} 2$ & 5ogeD & NST \\
\hline SLC35 & Q8IY50 & SLC35F3 & 2.A.7.24 & 405.4 & EamA & 32.3 & Putative thiamine transporter SLC35F3 & 6ukjA & NST \\
\hline SLC35 & A4IF30 & SLC35F4 & 2.A.7.24 & 431.6 & EamA & 22.9 & Solute carrier family 35 member F4 & 6ukjA & NST \\
\hline SLC35 & Q8WV83 & SLC35F5 & 2.A.7.24 & 428 & EamA & 45.4 & Solute carrier family 35 member F5 & 6ukjA & NST \\
\hline SLC35 & Q8N357 & SLC35F6 & 2.A.7.12 & 321.6 & EamA & 51.9 & Solute carrier family 35 member F6 & $5 y 78 \mathrm{~A}$ & NST \\
\hline SLC35 & Q2M3R5 & SLC35G1 & 2.A.7.28 & 369.1 & EamA & 96.5 & Solute carrier family 35 member G1 & $5 \mathrm{i} 20 \mathrm{D}$ & NST \\
\hline SLC35 & Q8TBE7 & SLC35G2 & 2.A.7.28 & 421.1 & EamA & 70.6 & Solute carrier family 35 member $\mathrm{G} 2$ & 6ukjA & NST \\
\hline SLC35 & Q8N808 & SLC35G3 & 2.A.7.28 & 347.3 & EamA & 40.8 & Solute carrier family 35 member $\mathrm{G} 3$ & 5ogeG & NST \\
\hline SLC35 & P0C7Q5 & SLC35G4 & 2.A.7.28 & 354.6 & EamA & 41.3 & Putative solute carrier family 35 member G4 & $5 \mathrm{i} 20 \mathrm{D}$ & NST \\
\hline SLC35 & Q96KT7 & SLC35G5 & 2.A.7.28 & 352.8 & EamA & 37.5 & Solute carrier family 35 member G5 & 5ogeG & NST \\
\hline SLC35 & P0C7Q6 & SLC35G6 & 2.A.7.28 & 353.9 & EamA & 42.3 & Solute carrier family 35 member $\mathrm{G} 6$ & 5ogeG & NST \\
\hline SLC36 & Q7Z2H8 & SLC36A1 & 2.A.18.8 & 816.6 & Aa_trans & 257.1 & Proton-coupled amino acid transporter 1 & $7 \mathrm{kgvB}$ & APC \\
\hline SLC36 & Q495M3 & SLC36A2 & 2.A.18.8 & 803.5 & Aa_trans & 248.3 & Proton-coupled amino acid transporter 2 & $7 \mathrm{kgvB}$ & APC \\
\hline SLC36 & Q495N2 & SLC36A3 & 2.A.18.8 & 737.4 & Aa_trans & 230.9 & Proton-coupled amino acid transporter 3 & $7 \mathrm{kgvB}$ & APC \\
\hline SLC36 & Q6YBV0 & SLC36A4 & 2.A.18.8 & 767.4 & Aa_trans & 258.7 & Proton-coupled amino acid transporter 4 & $7 \mathrm{kgvB}$ & APC \\
\hline SLC37 & P57057 & SLC37A1 & 2.A.1.4 & 575.6 & MFS_1 & 123.4 & Glucose-6-phosphate exchanger SLC37A1 & $1 \mathrm{pw} 4 \mathrm{~A}$ & MFS \\
\hline SLC37 & Q8TED4 & SLC37A2 & 2.A.1.4 & 568.1 & MFS_1 & 145 & Glucose-6-phosphate exchanger SLC37A2 & 4j05A & MFS \\
\hline SLC37 & Q8NCC5 & SLC37A3 & 2.A.1.4 & 515.3 & MFS_1 & 129.5 & Sugar phosphate exchanger 3 & $4 \mathrm{j05A}$ & MFS \\
\hline SLC37 & 043826 & SLC37A4 & 2.A.1.4 & 474.2 & MFS_1 & 171.1 & Glucose-6-phosphate exchanger SLC37A4 & $6 \mathrm{fmrA}$ & MFS \\
\hline SLC38 & Q9H2H9 & SLC38A1 & 2.A.18.6 & 440.8 & Aa_trans & 266.4 & Sodium-coupled neutral amino acid transporter 1 & $7 \mathrm{kgvB}$ & APC \\
\hline SLC38 & Q96QD8 & SLC38A2 & 2.A.18.6 & 478 & Aa_trans & 263.2 & Sodium-coupled neutral amino acid transporter 2 & $7 \mathrm{kgvB}$ & APC \\
\hline SLC38 & Q99624 & SLC38A3 & 2.A.18.6 & 479.3 & Aa_trans & 373.3 & Sodium-coupled neutral amino acid transporter 3 & $7 \mathrm{kgvB}$ & APC \\
\hline SLC38 & Q96916 & SLC38A4 & 2.A.18.6 & 485.3 & Aa_trans & 274.8 & Sodium-coupled neutral amino acid transporter 4 & $7 \mathrm{kgvB}$ & APC \\
\hline SLC38 & Q8WUX1 & SLC38A5 & 2.A.18.6 & 450.3 & Aa_trans & 295.9 & Sodium-coupled neutral amino acid transporter 5 & $7 \mathrm{kgvB}$ & APC \\
\hline SLC38 & Q8IZM9 & SLC38A6 & 2.A.18.6 & 393.7 & Aa_trans & 261.1 & Probable sodium-coupled neutral amino acid transporter 6 & $7 \mathrm{kgvB}$ & APC \\
\hline SLC38 & Q9NVC3 & SLC38A7 & 2.A.18.6 & 340.7 & Aa_trans & 187.8 & Putative sodium-coupled neutral amino acid transporter 7 & $7 \mathrm{~d} 10 \mathrm{~A}$ & APC \\
\hline SLC38 & A6NNN8 & SLC38A8 & 2.A.18.6 & 317 & Aa_trans & 180.4 & Putative sodium-coupled neutral amino acid transporter 8 & $7 \mathrm{kgvB}$ & APC \\
\hline
\end{tabular}




\begin{tabular}{|c|c|c|c|c|c|}
\hline SLC38 & Q8NBW4 & SLC38A9 & 2.A.18.9 & 1225 & Aa_trans \\
\hline SLC38 & Q9HBRO & SLC38A10 & 2.A.18.6 & 680 & Aa_trans \\
\hline SLC38 & Q08AI6 & SLC38A11 & 2.A.18.6 & 340 & Aa_trans \\
\hline SLC39 & Q9NY26 & SLC39A1 & 2.A.5.3 & 313.6 & Zip \\
\hline SLC39 & Q9NP94 & SLC39A2 & 2.A.5.3 & 314.3 & Zip \\
\hline SLC39 & Q9BRY0 & SLC39A3 & 2.A.5.3 & 310.5 & Zip \\
\hline SLC39 & Q6P5W5 & SLC39A4 & 2.A.5.4 & 530.6 & Zip \\
\hline SLC39 & Q6ZMH5 & SLC39A5 & 2.A.5.4 & 469.3 & Zip \\
\hline SLC39 & Q13433 & SLC39A6 & 2.A.5.4 & 601.8 & Zip \\
\hline SLC39 & Q92504 & SLC39A7 & 2.A.5.4 & 354.4 & Zip \\
\hline SLC39 & Q9C0K1 & SLC39A8 & 2.A.5.4 & 436.9 & Zip \\
\hline SLC39 & Q9NUM3 & SLC39A9 & 2.A.5.6 & 698.5 & Zip \\
\hline SLC39 & Q9ULF5 & SLC39A10 & 2.A.5.4 & 598 & Zip \\
\hline SLC39 & Q8N1S5 & SLC39A11 & 2.A.5.5 & 271.8 & Zip \\
\hline SLC39 & Q504Y0 & SLC39A12 & 2.A.5.4 & 532.3 & Zip \\
\hline SLC39 & Q96H72 & SLC39A13 & 2.A.5.4 & 298.4 & Zip \\
\hline SLC39 & Q15043 & SLC39A14 & 2.A.5.4 & 473.7 & Zip \\
\hline SLC40 & Q9NP59 & SLC40A1 & 2.A.100.1 & 734 & FPN1 \\
\hline SLC41 & Q8IVJ1 & SLC41A1 & 1.A.26.2 & 858.3 & MgtE \\
\hline SLC41 & Q96JW4 & SLC41A2 & 1.A.26.2 & 866.9 & MgtE \\
\hline SLC41 & Q96GZ6 & SLC41A3 & 1.A.26.2 & 810.5 & MgtE \\
\hline SLC42 & Q02094 & RHAG & 1.A.11.4 & 625.4 & Ammonium_transp \\
\hline SLC42 & Q9H310 & RHBG & 1.A.11.4 & 622.5 & Ammonium_transp \\
\hline SLC42 & Q9UBD6 & RHCG & 1.A.11.4 & 696.7 & Ammonium_transp \\
\hline SLC43 & 075387 & SLC43A1 & 2.A.1.44 & 1014 & MFS_1 \\
\hline SLC43 & Q8N370 & SLC43A2 & 2.A.1.44 & 1027.6 & MFS_1 \\
\hline SLC43 & Q8NBI5 & SLC43A3 & 2.A.1.44 & 794.4 & MFS_1 \\
\hline SLC44 & Q8WWI5 & SLC44A1 & 2.A.92 & 902.2 & Choline_transpo \\
\hline SLC44 & Q8IWA5 & SLC44A2 & 2.A.92 & 1006.1 & Choline_transpo \\
\hline SLC44 & Q8N4M1 & SLC44A3 & 2.A.92 & 824 & Choline_transpo \\
\hline SLC44 & Q53GD3 & SLC44A4 & 2.A.92 & 945.4 & Choline_transpo \\
\hline SLC44 & Q8NCS7 & SLC44A5 & 2.A.92 & 970 & Choline_transpo \\
\hline SLC45 & Q9Y2W3 & SLC45A1 & 2.A.2.4 & 772.4 & MFS_1 \\
\hline SLC45 & Q9UMX9 & SLC45A2 & 2.A.2.4 & 656.2 & MFS_1 \\
\hline SLC45 & Q96JT2 & SLC45A3 & 2.A.2.4 & 579.4 & MFS_1 \\
\hline SLC45 & Q5BKX6 & SLC45A4 & 2.A.2.4 & 795.8 & MFS_2 \\
\hline SLC46 & Q96NT5 & SLC46A1 & 2.A.1.50 & 663.5 & MFS_1 \\
\hline SLC46 & Q9BY10 & SLC46A2 & 2.A.1.50 & 658.3 & MFS_1 \\
\hline SLC46 & Q7Z3Q1 & SLC46A3 & 2.A.1.50 & 681.4 & MFS_1 \\
\hline SLC47 & Q96FL8 & SLC47A1 & 2.A.66.1 & 553.5 & MatE \\
\hline SLC47 & Q86VL8 & SLC47A2 & 2.A.66.1 & 561.8 & MatE \\
\hline SLC48 & Q6P1K1 & SLC48A1 & 2.A.110.1 & 167.8 & HRG \\
\hline SLC49 & Q9Y5Y0 & SLC49A1 (FLVCR1) & 2.A.1.28 & 763.5 & MFS 1 \\
\hline SLC49 & Q9UPI3 & SLC49A2 (FLVCR2) & 2.A.1.28 & 719.7 & MFS_1 \\
\hline SLC49 & Q6UXD7 & SLC49A3 & 2.A.1.28 & 489.2 & MFS_1 \\
\hline SLC49 & Q96SL1 & SLC49A4 & 2.A.1.28 & 584.3 & MFS_1 \\
\hline SLC50 & Q9BRV3 & SLC50A1 & 2.A.123.1 & 176.5 & MtN3_slv \\
\hline SLC51 & Q86UW1 & SLC51A & 2.A.82-Solute_trans_a & 404.7 & Solute_trans_a \\
\hline SLC51 & Q86UW2 & SLC51B & 2.A.82-OSTbeta & 162 & OSTbeta \\
\hline SLC52 & Q9NWF4 & SLC52A1 & 2.A.125 & 535 & \begin{tabular}{|l|} 
DUF1011 \\
\end{tabular} \\
\hline
\end{tabular}

98.2 Sodium-coupled neutral amino acid transporter 9 179.5 Putative sodium-coupled neutral amino acid transporter 10 179 Putative sodium-coupled neutral amino acid transporter 11 199.1 Zinc transporter ZIP1

216.9 Zinc transporter ZIP2

202.9 Zinc transporter ZIP4

220.5 Zinc transporter

348.4 Zinc transporter ZIP6

\begin{tabular}{l|l|l|l}
268.3 & Zinc transporter SLC39A7 & 5tsaA & ZIP
\end{tabular}

242.1 Zinc transporter ZIP8

132.1 Zinc transporter ZIP9

347.3 Zinc transporter ZIP10

86.8 Zinc transporter ZIP11

\begin{tabular}{|l|l|}
217.4 & Zinc transporter ZIP12 \\
\hline 181.8 & Zinc transporter ZIP13 \\
\hline 221.7 & Zinc transporter ZIP14
\end{tabular}

221.7 Zinc transporter ZIP14

642 Solute carrier family 40 member 1

183.1 Solute carrier family 41 member 1

174.8 Solute carrier family 41 member 2

163 Solute carrier family 41 member 3

309.3 Ammonium transporter Rh type $A$

244.2 Ammonium transporter Rh type B

265.5 Ammonium transporter Rh type $C$

\begin{tabular}{l|l|l|l}
55.5 & Large neutral amino acids transporter small subunit 3 & 3hd6A & Amt \\
\hline 56.6 & Larg & 7ckoA & MFS
\end{tabular}

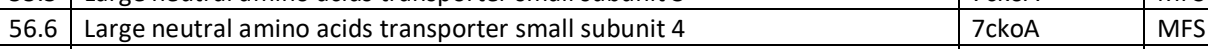

44.1 Solute carrier family 43 member 3

354.7 Choline transporter-like protein 1

369.2 Choline transporter-like protein 2

303.6 Choline transporter-like protein 3

366.3 Choline transporter-like protein 4

364.1 Choline transporter-like protein 5

64.5 Proton-associated sugar transporter $A$

47.5 Membrane-associated transporter protein

48.5 Solute carrier family 45 member 3

32.9 Solute carrier family 45 member 4

52.1 Thymic stromal cotransporter homolog

66 Solute carrier family 46 member 3

210 Multidrug and toxin extrusion protein 1

196.3 Multidrug and toxin extrusion protein 2

92.2 Heme transporter HRG1

94.4 Feline leukemia virus subgroup C receptor-related protein 1

95.5 Feline leukemia virus subgroup $C$ receptor-related protein 2

74.2 Solute carrier family 49 member $\mathrm{A} 3$

29.8 Solute carrier family 49 member 4

200.4 Sugar transporter SWEET1

125 Organic solute transporter subunit al pha

187.5 Organic solute transporter subunit beta

122 Solute carrier family 52, riboflavin transporter, member 1

MFS




\section{Supplementary File 1}

Phylogenetic trees of SLC-like protein families with more than two members. Trees were generated using multiple alignment by ClustalO, maximum likelihood tree generation by PhyML, followed by tree reconciliation with the species tree using NOTUNG (see Methods). The species tree with internal names of putative ancestor taxa is shown on each page on the upper-right hand corner. The trees are shown as dendrograms and branch lengths are not indicative of evolutionary distance. Each tree leaf corresponds to an SLC-like protein sequence denoting a gene, labels show the gene symbol, UniProt accession and taxon name. Leaves with labels ending with "*LOST" denote putative genes lost in the indicated ancestral species. Red " $\mathrm{D}$ " denote gene duplication nodes, normal nodes correspond to speciation nodes. Light green numbers denote branch support values as calculated by NOTUNG.

<Link: slc-all-trees.pdf> 